In collaboration with the

U.S. Environmental Protection Agency, Region V, and the Michigan Department of Environmental Quality

\title{
Historical and Simulated Changes in Channel Characteristics of the Kalamazoo River, Plainwell to Otsego, Michigan
}

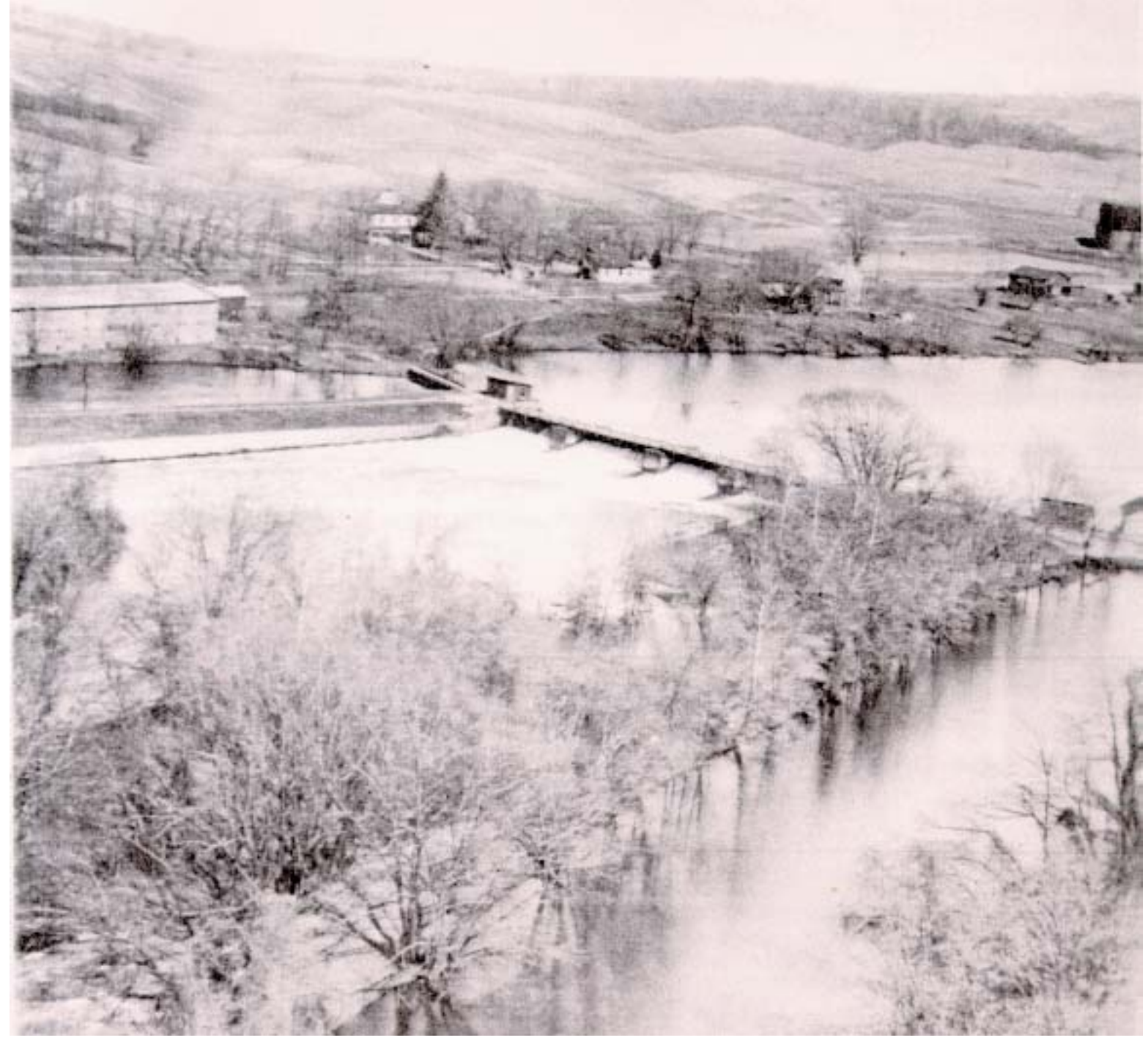

Scientific Investigations Report 2005-5044 
Cover photograph: Early 1900s Otsego City Dam on the Kalamazoo River in Otsego, Michigan. Photographer unknown. 


\section{Historical and Simulated Changes in Channel Characteristics of the Kalamazoo River, Plainwell to Otsego, Michigan}

By Cynthia M. Rachol, Faith A. Fitzpatrick, and Tiffiny Rossi

In cooperation with the

U.S. Environmental Protection Agency, Region V, and the

Michigan Department of Environmental Quality

Scientific Investigations Report 2005-5044 


\title{
U.S. Department of the Interior \\ Gale A. Norton, Secretary
}

\section{U.S. Geological Survey Patrick Leahy, Acting Director}

\author{
U.S. Geological Survey, Reston, Virginia: 2005 \\ For sale by U.S. Geological Survey, Information Services \\ Box 25286, Denver Federal Center \\ Denver, CO 80225
}

\begin{abstract}
For more information about the USGS and its products:
Telephone: 1-888-ASK-USGS

World Wide Web: http://www.usgs.gov/

Any use of trade, product, or firm names in this publication is for descriptive purposes only and does not imply endorsement by the U.S. Government.

Although this report is in the public domain, permission must be secured from the individual copyright owners to reproduce any copyrighted materials contained within this report.
\end{abstract}

Suggested citation:

Rachol, C.M., Fitzpatrick, F.A., and Rossi, T., 2005, Historical and simulated changes in channel characteristics of the Kalamazoo River, Plainwell to Otsego, Michigan: U.S. Geological Survey Scientific Investigations Report 2005-5044, $62 \mathrm{p}$. 


\section{Contents}

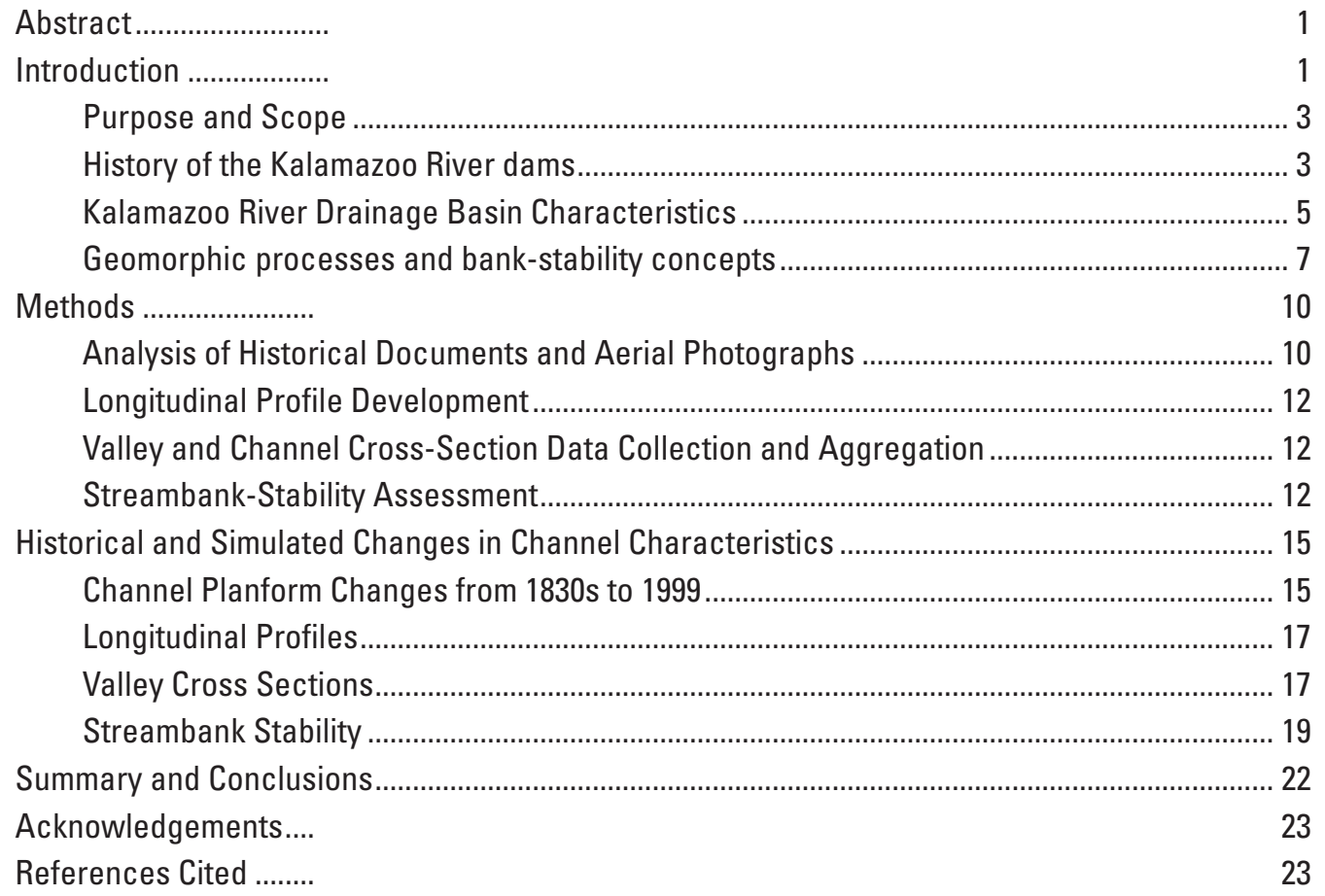

Appendix A. Valley and designed channel cross sections for the Kalamazoo River from

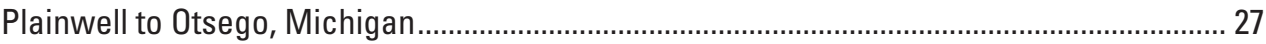

Appendix B. Geotechnical parameters from field tests of streambanks for the Kalamazoo

River from Plainwell to Otsego, Michigan ......................................................................... 47

Appendix C. Maps showing channel change from early to mid-1830s to 1999 at selected

locations on the Kalamazoo River, Michigan 49

\section{Figures}

1-7. Maps showing:

1. Location of the Kalamazoo River and detailed Study area in Michigan ........................... 2

2. Locations of major dams within the Kalamazoo River drainage basin, Michigan ............ 4

3. Surficial geology of the Kalamazoo River drainage basin, Michigan ............................. 5

4. Soil distribution in the Kalamazoo River drainage basin, Michigan ................................ 6

5. Location of U.S. Geological Survey stream-gaging stations in the Kalamazoo River drainage basin, Michigan....................................................................................... 7

6. Land cover in the Kalamazoo River drainage basin, Michigan, 1997 to 2000.................... 8

7. Pre-settlement (1816-1856) land cover in the Kalamazoo River drainage basin, Michigan ....... 8

8-10. Diagrams showing:

8. Sediment zones shown in reference to a watershed in plan view and longitudinally..... 9

9. Common landform features related to streams 
10. Different modes of streambank failure......................................................................... 10

11. Map showing location of bank models on the Kalamazoo River, Michigan ................... 14

12-13. Graphs showing:

12. Flow rates used in SEDMOD sediment transport model under 2001-02 flow conditions and 1947 spring flood conditions with dams removed, Kalamazoo River, Michigan 15

13. Longitudinal profile of the Kalamazoo River, Michigan, from its headwaters to mouth at Lake Michigan..

14. Map showing locations of valley cross sections in the Plainwell to Otsego reach of the Kalamazoo River, Michigan

15-19. Graphs showing:

15. Example cross section of the Kalamazoo River Valley, Michigan

16. Cross sections 54.41 and 53.05 for present conditions and designed channel with dams removed, Kalamazoo River, Michigan.

17. Longitudinal profile of present thalweg, present hard bottom lowest elevation, and designed channel thalweg in the Plainwell to Otsego reach of the Kalamazoo River, Michigan.....

18. Planform of desgined channel and approximate area with impounded sediment, Kalamazoo River, Michigan

19. Water surface profiles for the HEC-RAS simulation of bankfull flood and floods in the design channel with 2- and 50-year recurrence interval

20-22. Photographs showing:

20. Undercut banks typical of the Plainwell to Otsego reach................................................. 22

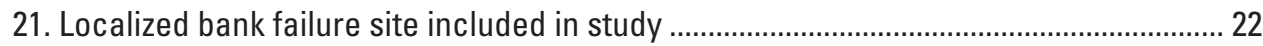

22. Material eroded from the bank becomes part of the bank toe ........................................ 22

\section{Tables}

1. Slopes used in bank-stability assessment for present and dams-removed scenarios,

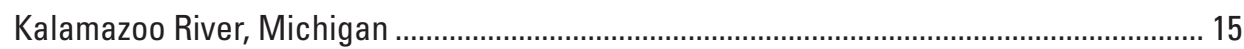

2. Factor of safety predicted by bank-stability model under present conditions.................... 20

3. Factor of safety predicted by bank-stability model under dams-removed conditions ...... 21 


\section{Conversion Factors, Datum, and Abbreviations}

\begin{tabular}{lrll}
\hline & Multiply & By & To obtain \\
\hline \multirow{2}{*}{ Length } & mile $(\mathrm{mi})$ & 1.609 & kilometer $(\mathrm{km})$ \\
& foot $(\mathrm{ft})$ & 0.3048 & meter $(\mathrm{m})$ \\
& inch $(\mathrm{in})$. & 25.4 & millimeter $(\mathrm{mm})$ \\
$\underline{\text { Area }}$ & square mile $\left(\mathrm{mi}^{2}\right)$ & 2.590 & square $\operatorname{kilometer}\left(\mathrm{km}^{2}\right)$ \\
& square foot $\left(\mathrm{ft}^{2}\right)$ & 0.09290 & square meter $\left(\mathrm{m}^{2}\right)$ \\
$\underline{\text { Volume }}$ & cubic yards $\left(\mathrm{yd} \mathrm{d}^{3}\right)$ & 0.7646 & cubic meter $\left(\mathrm{m}^{3}\right)$ \\
$\underline{\text { Mass }}$ & cubic foot per second $\left(\mathrm{ft}^{3} / \mathrm{s}\right)$ & 0.02832 & cubic meter per second $\left(\mathrm{m}^{3} / \mathrm{s}\right)$ \\
& milligram $(\mathrm{mg})$ & 0.00003527 & ounce, avoirdupois $(\mathrm{oz})$ \\
& kilogram $(\mathrm{kg})$ & 2.205 & pound, avoirdupois $(\mathrm{lb})$ \\
& & & \\
\hline
\end{tabular}

Vertical coordinate information is referenced to the North American Vertical Datum of 1988 (NAVD 88).

\section{Abbreviations used in this report:}

\begin{tabular}{|c|c|}
\hline ARS & United States Department of Agriculture, Agriculture Research Service \\
\hline BBL & Blasland, Bouck, and Lee, Inc. \\
\hline DEM & Digital Elevation Model \\
\hline $\mathrm{D} 00$ & Digital $\underline{\text { Orthoquadrangle }}$ \\
\hline DPI & Dots per Inch \\
\hline DRG & Digital Raster Graphic \\
\hline FGDC & Federal Geographic Data Committee \\
\hline GLO & Government Land $\underline{\text { Office }}$ \\
\hline MDEO & Michigan Department of Environmental Quality \\
\hline MDNR & Michigan Department of Natural Resources \\
\hline NMAS & 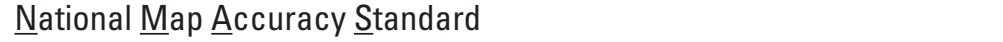 \\
\hline NSSDA & National Standard for $\underline{S}$ patial Data Accuracy \\
\hline OSL & Optical Science Lab \\
\hline РСВ & Polychlorinated Biphenyl \\
\hline TIFF & Tagged Image File Format \\
\hline USEPA & $\underline{\text { United }} \underline{\text { States }}$ Environmental Protection Agency \\
\hline USGS & United ŚStates Geological Survey \\
\hline
\end{tabular}




\title{
Historical and Simulated Changes in Channel Characteristics of the Kalamazoo River, Plainwell to Otsego, Michigan
}

\author{
By Cynthia M. Rachol, Faith A. Fitzpatrick, and Tiffiny Rossi
}

\section{ABSTRACT}

In a study to understand the historical effects of the construction and decommissioning of dams on the Kalamazoo River, Plainwell to Otesgo, Michigan, and to simulate channel changes that may result if the dams were removed, early to mid-1800s General Land Office surveys and aerial photographs from 1938, 1981, and 1999 were compared in order to identify historical changes in the river's planform. This analysis of the 80-mile reach from Morrow Dam to the river mouth at Saugatuck provided insight into how susceptible the river has been to channel migration. The comparison showed that changes in channel width and location were caused mainly by construction of dams and subsequent water-level adjustments in the impounded reaches upstream from the dams. Braiding also occurred downstream from one of the dams. Minor changes in channel form that were not caused by the dams, such as the development and cutoff of meander bends, were observed.

A more detailed study in a 5-mile reach passing through the Plainwell and Otsego City Dams included compiling existing valley cross section and longitudinal profile data into a database, assessing bank stability, and using a hydrologic model to simulate the channel as if the dams were removed. Fifty-four valley cross sections compiled from United States Geological Survey and consultant data sets were used as a base for a bank-stability assessment and to design a hypothetical stable channel without the two dams. The channel design involved adjusting the slope, hydraulic geometry, and floodplain width to ensure that water could be transferred through the reach without increasing flooding or erosion problems.

The bank-stability assessment focused on conditions that are critical to failure. This was accomplished through the use of a two step process. The first involved evaluating the sediment removed from the bank toe when the stage is high. The second involved calculating the factor of safety for the bank based on the water table being elevated higher than the stage, mimicing a bank storage effect. Using these paired proccesses, two scenarios of critical conditions were evaluated: dams present and dams removed.

Results of the bank assessments showed that, under both critical-condition scenarios, the streambanks were more susceptible to toe erosion than to block failure. As toe erosion progresses, the banks will eventually collapse as supporting material underneath is removed. Toe erosion for the damsremoved scenario resulted in higher amounts of erosion than for the dams-present scenario, leading to an overall decrease in bank stability. Effects of vegetation on the bank stability were variable; stability for some banks increase if vegetation was present but remain the same for other banks.

\section{INTRODUCTION}

Dams, diversion structures, and channelization have affected the Kalamazoo River since the mid-1800s. Modification of the river has led to the development of a variety of depositional environments that would otherwise not have been present; some of these areas contain sediments contaminated with polychlorinated biphenyls (PCBs) from papermill carbonless copy paper recycling (Blasland, Bouck, and Lee, Inc., 1996). The sources of these contaminants are believed to be within the city of Plainwell and within and near the city of Kalamazoo, Mich. Downstream from these cities are four low-head dams on the river between Plainwell and Allegan, three of which are owned by the State of Michigan (fig. 1). These dams were built in the mid- to late 1800s and early 1900s and were used for power generation and industrial water supply. Most of the contaminated sediments were deposited in the dam impoundments during the 1950s to 1970s (Blasland, Bouck, and Lee, Inc., 1996). 


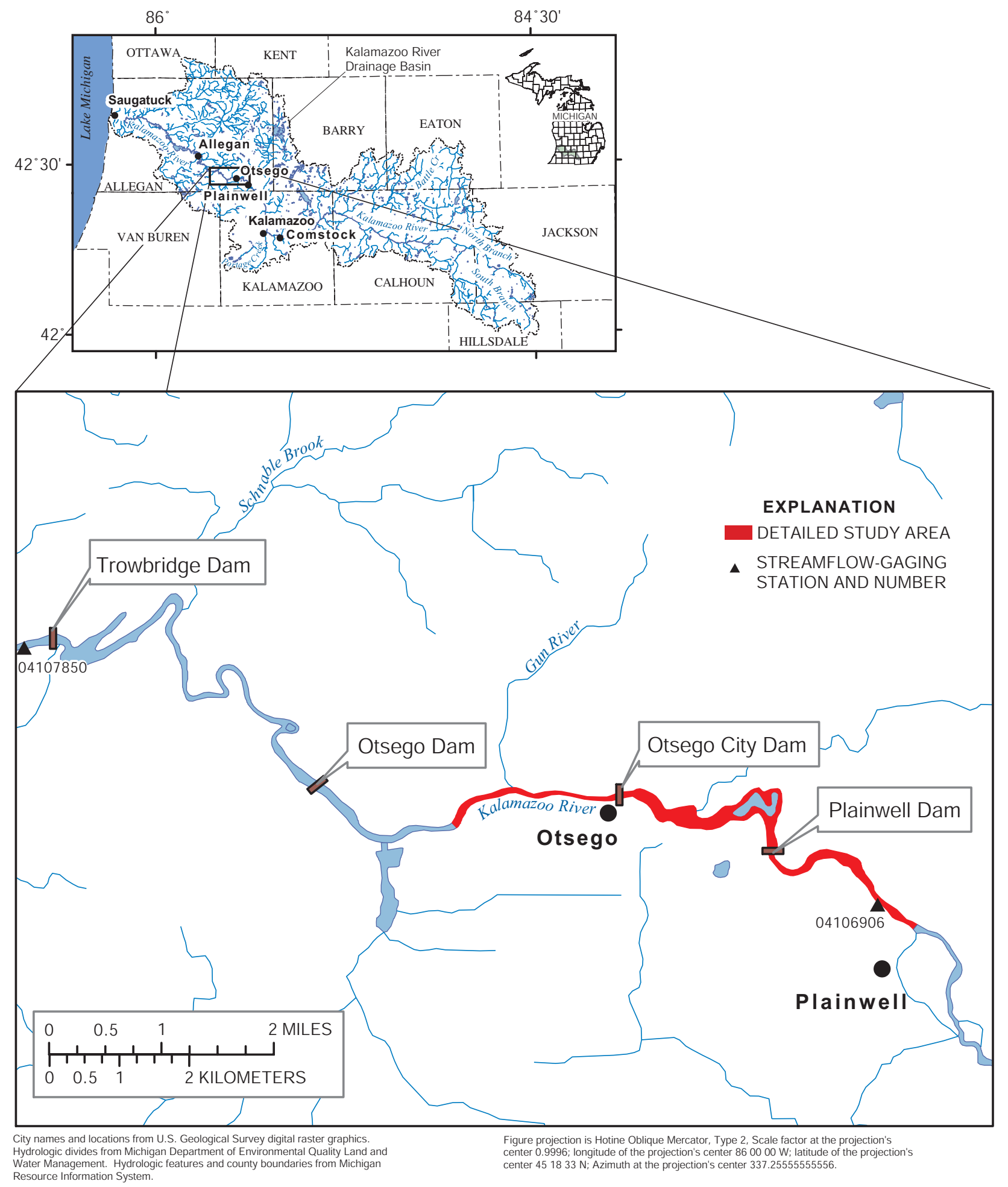

Figure 1. Location of the Kalamazoo River and detailed study area in Michigan.

In 1987, the superstructures (dam gates, turbines, and powerhouse) were removed from the State-owned Plainwell, Otsego, and Trowbridge dams leaving wingwalls and crests in place. In order to remove the superstructures, the pool levels were lowered exposing previously inundated flood-plain sediments which contain PCBs at elevated concentrations and causing the river to incise into the impoundment bottom. The remaining low-head structures are in poor condition; and the State-owned dams were reinforced in 2001 and the fourth dam is being evaluated (Todd King, Camp Dresser and McKee, oral commun. 2003). Despite efforts to keep the dams in place,

PCB-laden sediment continues to be transported and deposited downstream from each dam. 
The Michigan Department of Natural Resources (MDNR) is interested in removing the State-owned dams and restoring the river channel from Plainwell to below the Trowbridge Dam to its pre-dam conditions. The Michigan Department of Environmental Quality (MDEQ) and the U.S. Environmental Protection Agency (USEPA) are interested in understanding the present geomorphic condition of the river channel, its flood plain, wetlands, and previous depositional surfaces. All three agencies would like to develop a better understanding of what the river conditions were before the dams were built and to identify potential concerns should the dams be removed. The MDEQ and USEPA would like to identify areas susceptible to bank erosion and reaches prone to avulsion.

The goals of this study by the U. S. Geological Survey (USGS), in cooperation with the MDEQ and the USEPA, were to (1) provide a general description of the geologic and hydrologic setting of the Kalamazoo River, (2) identify historical changes in planform and slope, (3) provide hydraulic geometry and slope data for use in a U.S. Department of Agriculture, Agricultural Research Service (ARS) channel evolution model, and (4) assess bank stability. The ARS model (CONCEPTS) used the data produced in this study to simulate the Kalamazoo River under three scenarios: present conditions with the dams in place, present conditions with the dams removed, and possible conditions with the designed channel and the dams removed (Wells and others, 2003).

Although engineering studies and construction efforts have addressed the stabilization of some of the dams on the Kalamazoo River, the consequences of dam removal are basically unknown. This study provides data on the potential for mobilization, transport, and ultimate fate of PCB-laden sediment. Results from this study have substantial potential to advance the general understanding of geomorphic and sedimentation processes in rivers affected by dams and contamination problems. Data from this study will aid in making decisions regarding dam removal more cost effective and scientifically based. The State of Michigan, USEPA, and private consultants will use this information to help guide restoration, management, and cleanup efforts on the Kalamazoo River.

\section{Purpose and Scope}

This report describes the historical and potential future changes in channel shape, streambanks, and streambed for the Plainwell/Otsego reach, a detailed reach of the Kalamazoo River that includes two dams that are referred to as the Plainwell and Otsego City dams. The objectives of this report are to describe the general geologic and hydrologic conditions for the Kalamazoo River drainage basin, identify historical changes in channel planform and slope for the Kalamazoo River from the 1830s to 2002, develop methodologies for constructing valley cross sections and provide hydraulic geometry and slope data for the Plainwell/Otsego reach (river mile 51.23 to 56.67), and show the results of a bank-stability assessment through the study reach.

\section{History of the Kalamazoo River dams}

There are many historical accounts of dams being constructed in the Kalamazoo River and its tributaries. Most of these dams began as crudely assembled earthen structures, and others started out as wooden structures that were later rebuilt with stone or concrete. At present (2003), there are at least seven dams or instream remnants of dams (fig. 2). Because the most immediate need for remediation exists at the Plainwell, Otsego City, Otsego, and Trowbridge dams, the following historical discussion will concentrate on those dams.

All four dams were constructed to supply either mill power or hydroelectric power. Built in 1836, the Otsego City Dam is the oldest and is the only dam to presently (2003) have its gates in place (Nevins and Dalrymple, 1975). Sixty years after the construction of the Otsego City Dam, three hydroelectric dams were built in quick succession: the Trowbridge Dam in 1898, Plainwell Dam in 1899, and Otsego Dam in 1902 (D. Dalrymple, 1972, Dalrymple, 1983). The impounding of water behind the Otsego Dam forced the relocation of a settlement that was located where Pine Creek enters the Kalamazoo River (Dalrymple, 1983). The rest of the dams did not inundate any established communities when they were built.

From the 1900s to the 1960s, the three dams were actively used for power generation. In 1967, the dams were decommissioned from use and turned over to the State of Michigan (J. Bernier, Consumers Energy, oral commun., 2003). In 1973, the gates were permanently opened on the State-owned dams, lowering the water levels within the impoundments down to their sills (Anderson, 1991; Roy F. Weston, Inc., 2002). In 1987, demolition began on the superstructures of the three State-owned dams (Kalamazoo Gazette, 1987), reducing them to their present configuration. Each of the State-owned dams was inspected, and short-term reinforcements were added in the form of riprap, metal sheet wall, and grass matting (Todd King, Camp, Dresser, and McKee, oral commun., 2002).

Throughout this time, paper mills thrived upstream from the dams in the Plainwell and Kalamazoo areas. The period of greatest contaminant release is believed to be from 1950 to 1970 (Blasland, Bouck, and Lee, Inc., 1996). Some of the paper mills recycled carbonless paper, a process that produced a waste stream containing PCBs (Roy F. Weston, Inc., 2002). Until the early 1950s, paper mills in both Plainwell and Kalamazoo discharged wastewater directly into the Kalamazoo River and one of its tributaries, Portage Creek (Blasland, Bouck, and Lee, Inc. 1996). By the mid-1950s, all of the paper mills had treatment facilities in place. This new wastewater treatment system was combined to treat both the mills' industrial waste and the city's domestic waste (Kalamazoo Gazette, 1975, 1984). It was later realized after contaminants had been already released into the river, that the facilities were not sufficient to handle these types of inputs.

Many studies of the Kalamazoo River have been conducted since the early 1980s to determine the extent of the contamination (Simard, 2003). One of the most recent studies 


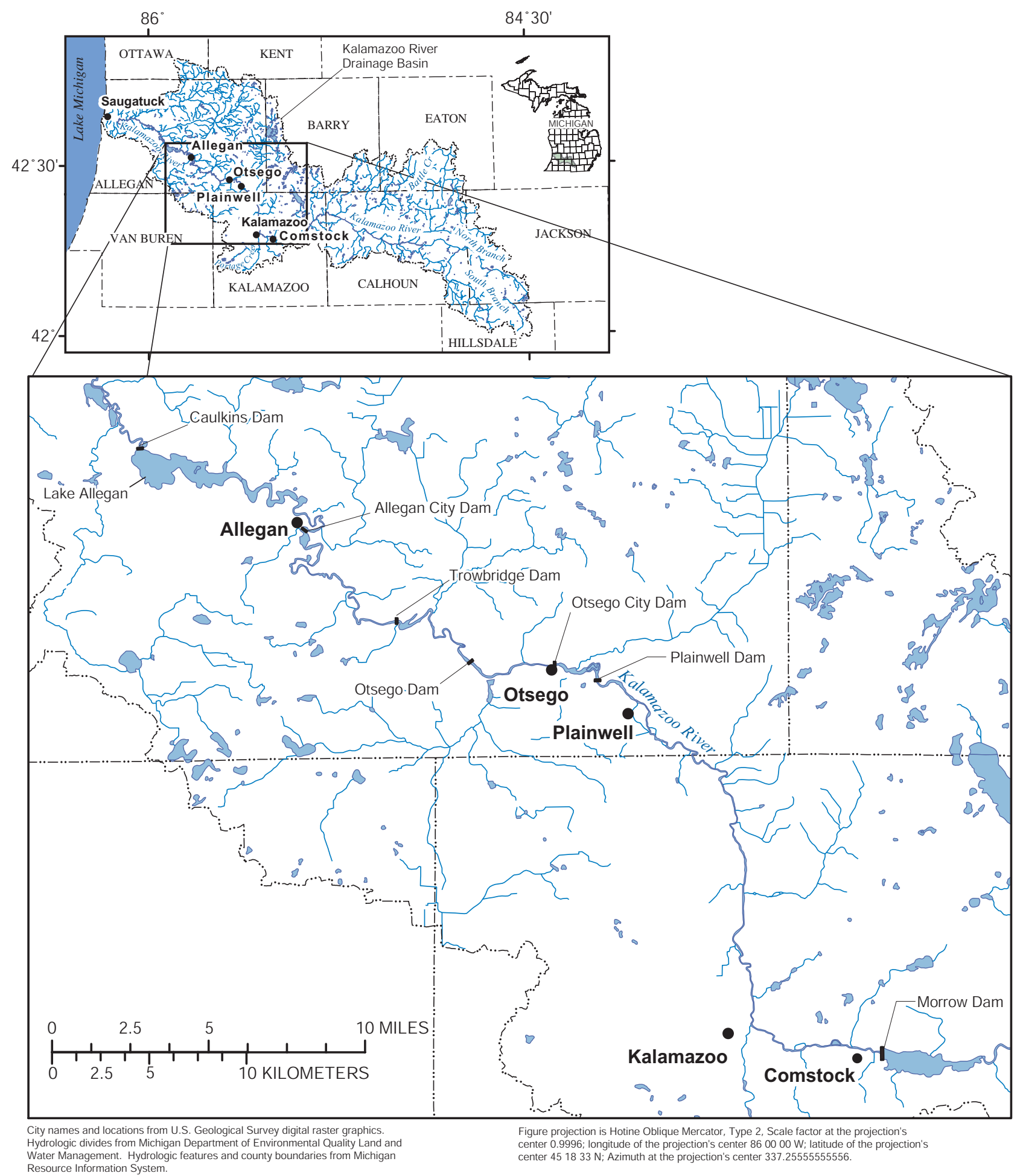

Figure 2. Locations of major dams within the Kalamazoo River drainage basin, Michigan.

was by Roy F. Weston, Inc. (2002), in which sediment samples were collected within the Plainwell and Otsego City impoundments and their surrounding flood plains and wetlands. The results of their analysis show that the maximum and minimum concentrations of PCBs within the banks of the river were $82,100 \mu \mathrm{g} / \mathrm{kg}$ and $5 \mu \mathrm{g} / \mathrm{kg}$, respectively; maximum and minimum concentrations within flood-plain and wetland samples were $84,100 \mu \mathrm{g} / \mathrm{kg}$ and $3 \mu \mathrm{g} / \mathrm{kg}$. In addition to PCBs, dioxins were detected.

The USGS has established stream-gaging stations above the Plainwell Dam and below the Trowbridge Dam, collected suspended- and bedload-sediment data, and conducted channel cross-section surveys that were used to develop a transport model to simulate the effects of dam removal. Additionally, 


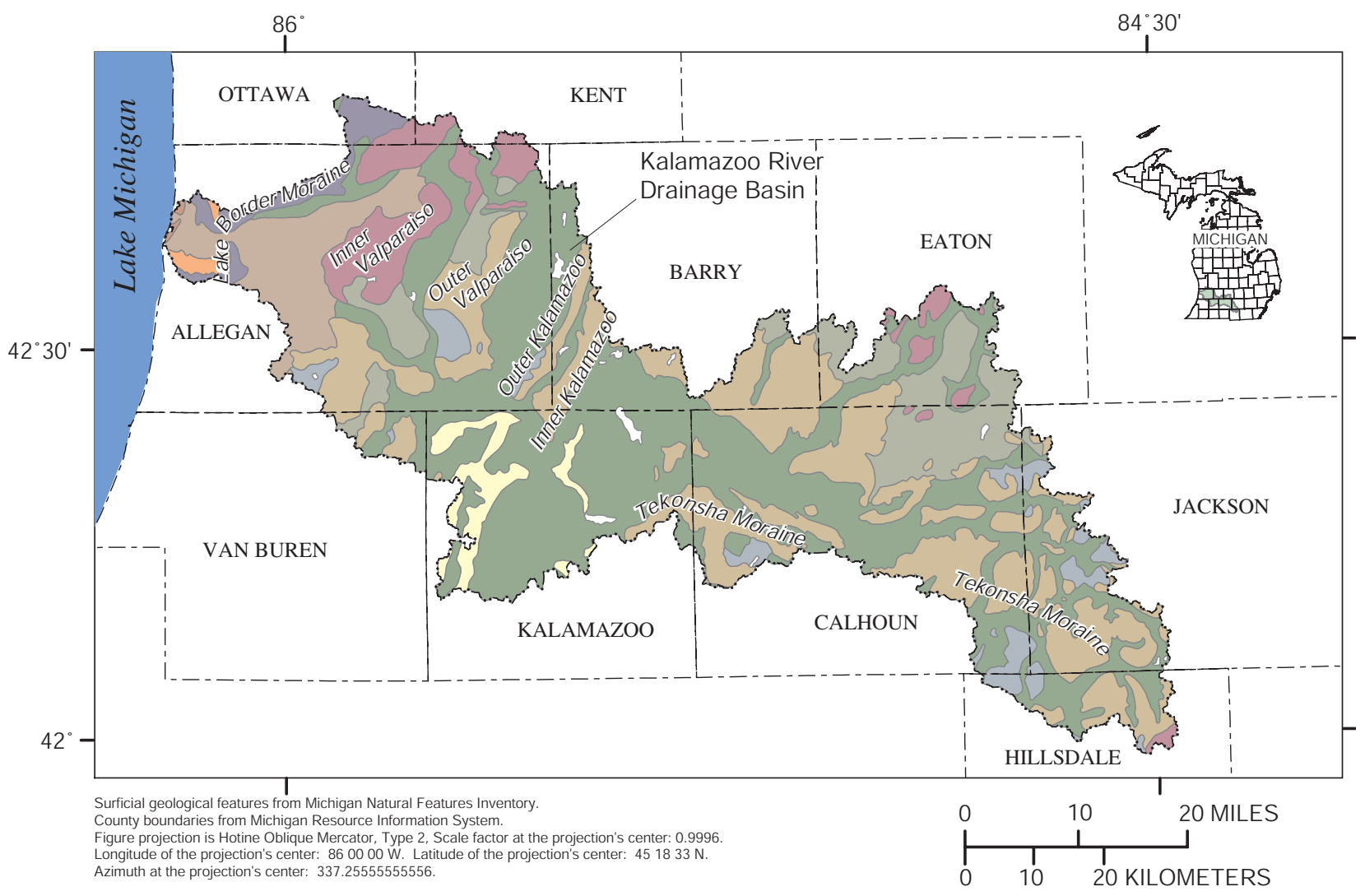

EXPLANATION

\section{FINE TEXTURED GLACIAL TILL \\ MEDIUM TEXTURED GLACIAL TILL \\ COARSE TEXTURED GLACIAL TILL \\ ICE CONTACT OUTWASH SAND AND GRAVEL \\ LACUSTRINE SAND AND GRAVEL}

END MORAINES OF FINE TEXTURED TILL END MORAINES OF MEDIUM TEXTURED TILL END MORAINES OF COARSE TEXTURED TILL DUNE SAND GLACIAL OUTWASH SAND AND GRAVEL, AND POSTGLACIAL ALLUVIUM

Figure 3. Surficial geology of the Kalamazoo River drainage basin, Michigan.

the USGS collected sediment cores from behind the four dams and quantified the volume of post-dam sediment that has accumulated behind each of the dams (Rheaume and others, 2002; 2003).

\section{Kalamazoo River Drainage Basin Characteristics}

The Kalamazoo River Basin has a drainage area of 2,020 $\mathrm{mi}^{2}$ and covers parts of 10 counties (Ottawa, Kent, Allegan, Barry, Eaton, Van Buren, Kalamazoo, Calhoun, Jackson, and Hillsdale; fig. 1). The Kalamazoo River is a sixth order, warm-water stream (Huggler, 1996). The river is approximately $123 \mathrm{mi}$. long from its headwaters in Calhoun County to its mouth at Lake Michigan in Allegan County. The topography consists of gently rolling hills; and the drainage-basin relief is $686 \mathrm{ft}$. Precipitation averages about $35.7 \mathrm{in}$. annually, with 56 percent occurring from April to September; the average seasonal snowfall is 79.7 in. (Knapp, 1987).
Six major sea inundations acted as the main depositional environment for the local bedrock units (Deutsch and others, 1960). The major bedrock units are Mississippian in age and include the Marshall Sandstone, Coldwater Shale, and Michigan Formation. Intense folding and erosion of the Marshall Sandstone resulted in exposure of the Coldwater Shale, which has been susceptible to valley formation (Riggs, 1938). The present-day Kalamazoo River occupies the bed of pre-glacial drainages within these valleys. Where the folding was less intense and erosion was not as severe, the Marshall Sandstone formed ridges. Prior to glaciation, these bedrock units were eroded to a low relief (Deutsch and others, 1960).

Advances and retreats of glaciers during the Pleistocene resulted in the deposition of thick glacial deposits that form the present topography (fig. 3). Moraines-distinct ridges of debris deposited directly or pushed by a glacier representing a stagnant position of ice-mark the drainage basin where many stages of glacial retreat took place. The Kalamazoo River cuts across three major morainal systems: the Inner and Outer 


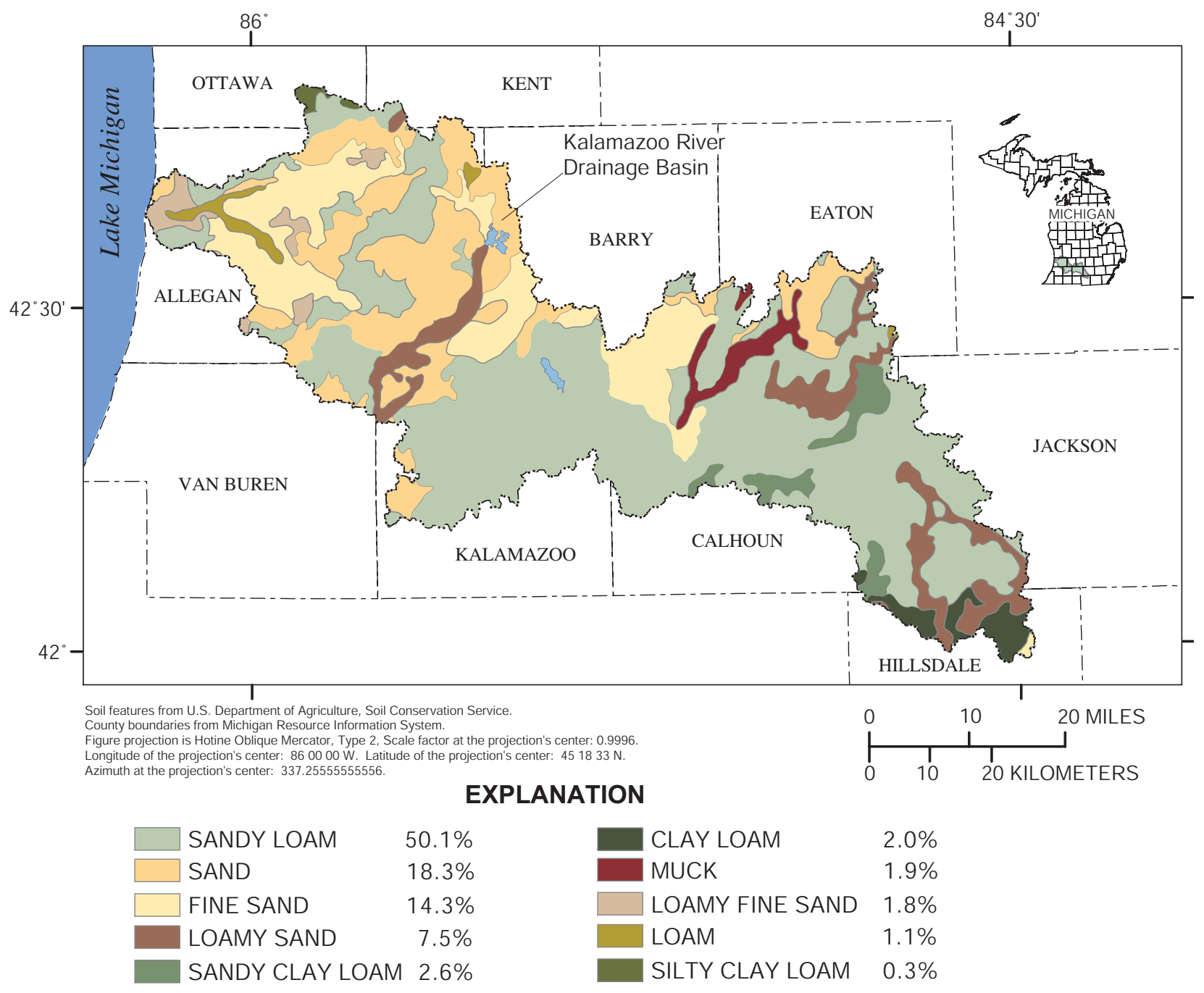

Figure 4. Soil distribution in the Kalamazoo River drainage basin, Michigan.

Kalamazoo Moraines in west-central Kalamazoo County, the Inner and Outer Valparaiso Moraines in east-central Allegan County, and the Lake Border Moraine in western Allegan County (Monaghan and Larson, 1984; Gephart and Larson, 1982). Glacial meltwater cut a channel through the moraine deposits and enabled the present channel to form despite these ridges.

Terrace remnants throughout the Kalamazoo River Valley are evidence of a predecessor to the modern Kalamazoo River (Monaghan and Larson, 1984). This proto-Kalamazoo River drained from the retreating Saginaw glacial lobe in the east and the Lake Michigan lobe in the west. The surrounding coarse-grained outwash and glacial till plains supply sand, gravel, and cobbles to the modern Kalamazoo River (fig. 3).

The three main soil types within the drainage basin are loam, sand, and muck (fig. 4). Loam, the dominant soil type, covers 56 percent of the drainage basin and ranges in texture from silty clay loam to sandy clay loam. Loam covers most of the eastern and central portions of the drainage basin, with patches in the western portion that are coincident with endmoraine deposits. Sand, which covers about 42 percent of the drainage basin, consists of sand, fine sand, loamy sand, and loamy fine sand. About 2 percent of the drainage basin area is muck (U.S. Department of Agriculture Soil Conservation Service, 1994).

A stream-gaging station has been operating on the Kalamazoo River at Comstock (USGS station 04106000) from 1931 to the present (Blumer and others, 2003; fig. 5). The drainage area at Comstock is about $1,010 \mathrm{mi}^{2}$. For the Comstock station's 72-year period of record, the mean annual streamflow is $896 \mathrm{ft}^{3} / \mathrm{s}$. The maximum daily mean flow of $6,830 \mathrm{ft}^{3} / \mathrm{s}$ occurred on April 8, 1947, and the minimum daily mean flow of $185 \mathrm{ft}^{3} / \mathrm{s}$ occurred on August 7, 1934 (Blumer and others, 2003). Historical and present stream-gaging stations on the Kalamazoo River and its tributaries are shown in figure 5 .

Land-cover data collected between 1997 and 2000 indicate that the Kalamazoo drainage basin is dominated by agricultural and forested land (fig. 6; Vogelmann and others, 2001).

Many historical accounts have described the area as being an ideal location for logging and agriculture. Much of the 


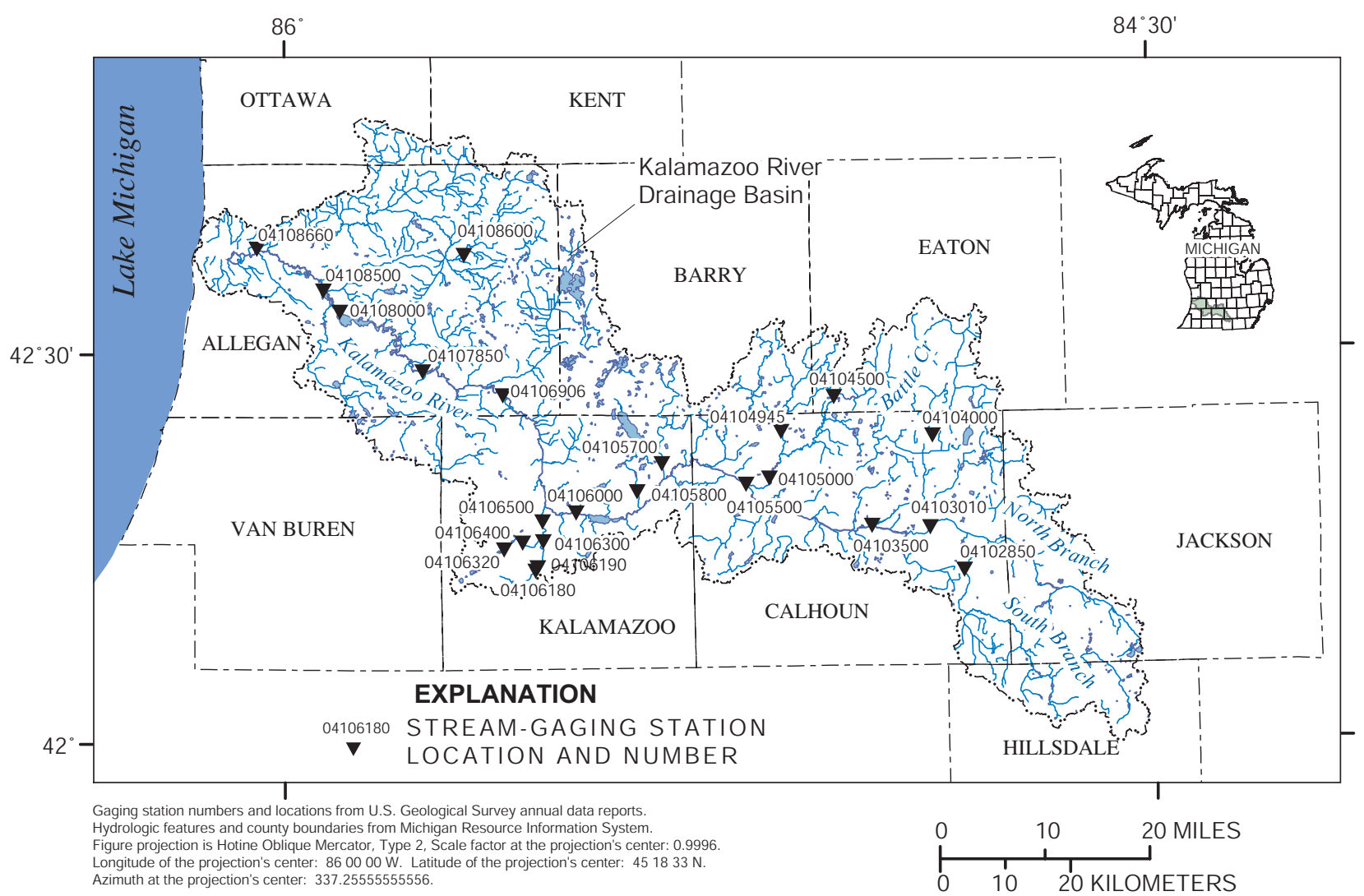

\begin{tabular}{ll}
$\begin{array}{c}\text { Station } \\
\text { Number }\end{array}$ & \multicolumn{1}{c}{ Name } \\
04102850 & South Branch Kalamazoo River near Albion \\
04103010 & Kalamazoo River near Marengo \\
04103500 & Kalamazoo River at Marshall \\
04104000 & Battle Creek at Kalamo Road at Charlotte \\
04104500 & Battle Creek at State Highway 78 at Bellevue \\
04104945 & Wanadoga Creek near Battle Creek \\
04105000 & Battle Creek at Battle Creek \\
04105500 & Kalamazoo River near Battle Creek \\
04105700 & Augusta Creek near Augusta \\
04105800 & Gull Creek at 37th Street near Galesburg \\
04106000 & Kalamazoo River at Comstock \\
04106180 & Portage Creek at Portage
\end{tabular}

Station Number

04106190 Portage Creek at Garden Line near Portage $04106300 \quad$ Portage Creek near Kalamazoo 04106320 West Fork Portage Creek near Oshtemo 04106400 West Fork Portage Creek at Kalamazoo $04106500 \quad$ Portage Creek at Kalamazoo $04106906 \quad$ Kalamazoo River at Plainwell $04107850 \quad$ Kalamazoo River near Allegan $04108000 \quad$ Kalamazoo River near Allegan (discontinued) $04108500 \quad$ Kalamazoo River near Fennville $04108600 \quad$ Rabbitt River near Hopkins $04108660 \quad$ Kalamazoo River at New Richmond

Figure 5. Location of U.S. Geological Survey stream-gaging stations in the Kalamazoo River drainage basin, Michigan.

European settlement grew around the mills on the Kalamazoo River. Prior to European settlement, vast forests, wetland, and grassland (fig. 7) dominated the drainage basin (Comer and others, 1998).

\section{Geomorphic processes and bank-stability concepts}

Stream channels are created by flowing water eroding and depositing sediment. Within a drainage basin, stream channels form networks in which erosion and deposition can be viewed as occurring in particular zones (fig. 8). Located in the headwaters of the drainage basin, the erosion zone is the source for much of the stream sediment and runoff. Towards the stream mouth, the channel gradient becomes gentler, and sediment is deposited. A transitional zone connects the erosion and deposition zones. In a stable stream channel, sediment moves through the transitional zone with no net gain or loss (Schumm, 1977). By looking at the location of a reach within its drainage basin, overall erosion and deposition processes can be put into perspective. 


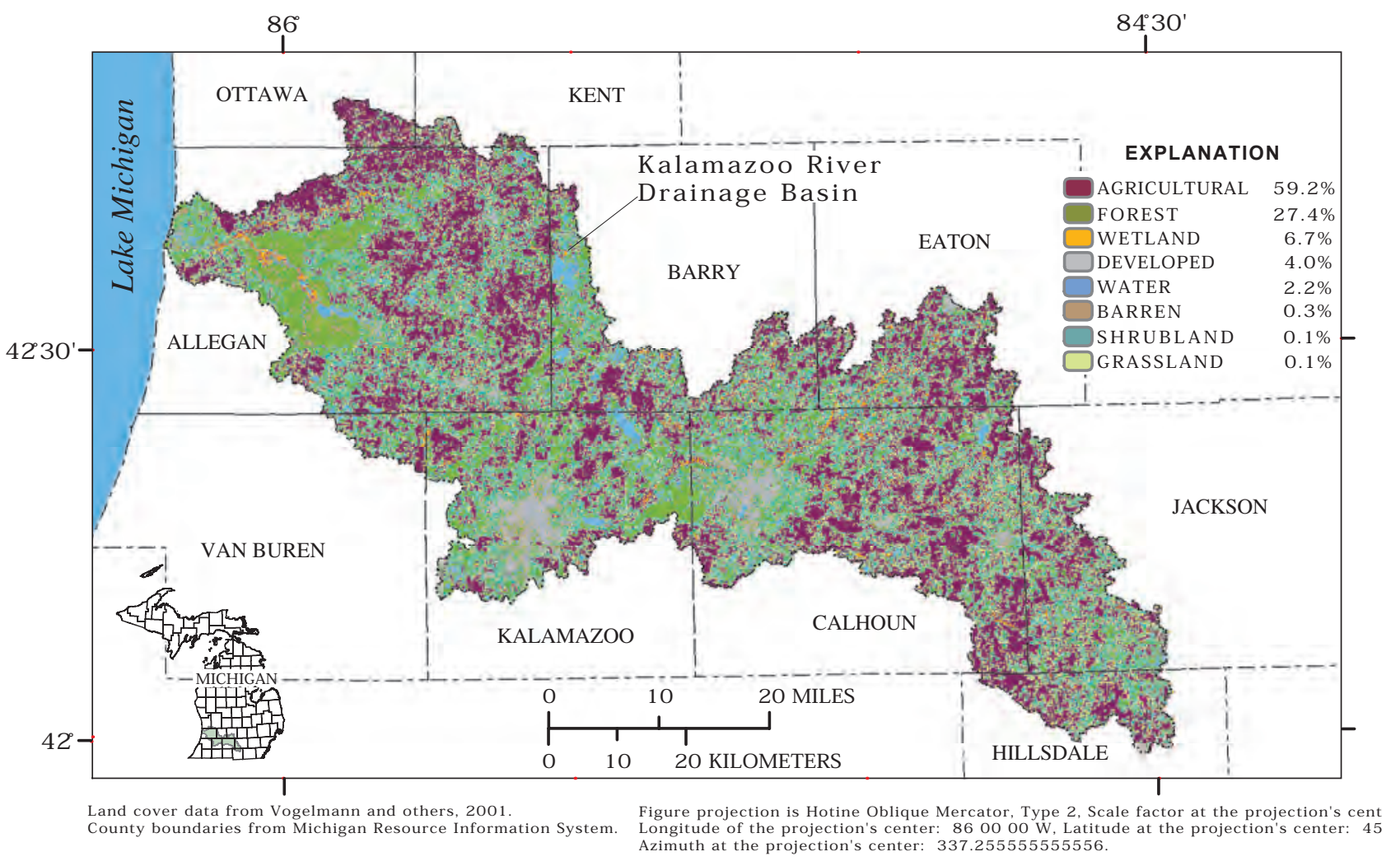

Figure 6. Land cover in the Kalamazoo River drainage basin, Michigan, 1997 to 2000.

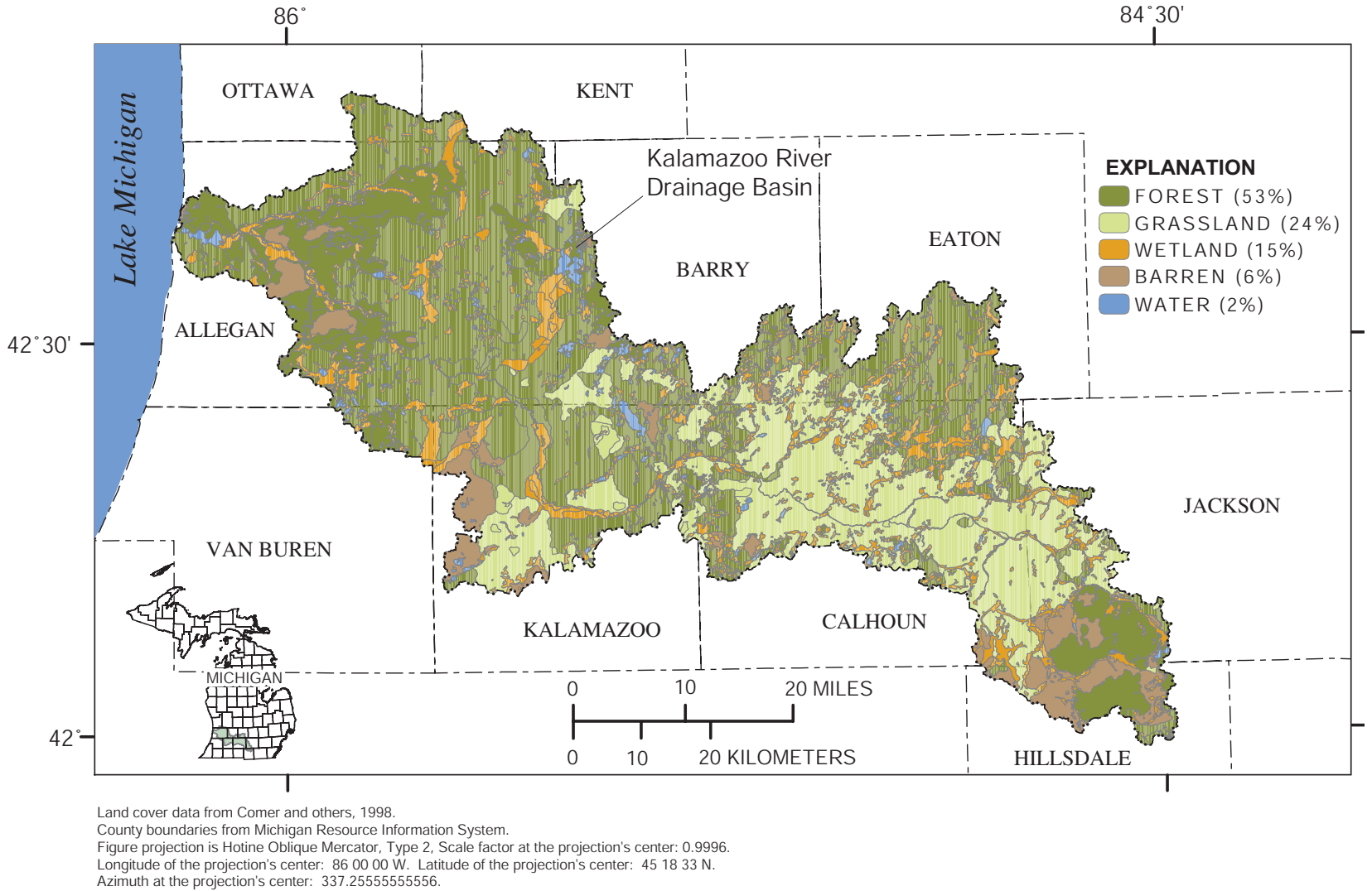

Figure 7. Pre-settlement (1816-56) land cover in the Kalamazoo River drainage basin, Michigan. 


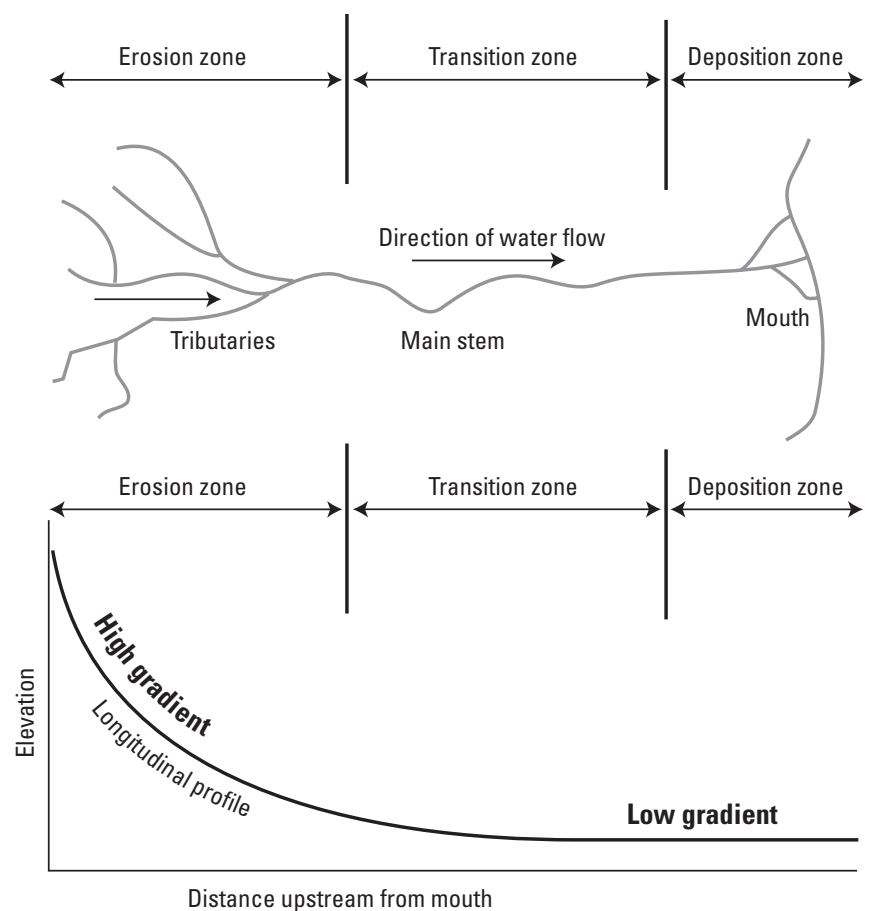

Figure 8. Sediment zones shown in reference to a watershed in plan view (top) and longitudinally (bottom, modified from Schumm, 1977).

Considered at a smaller scale, erosion and deposition lead to the formation of stream-channel features such as terraces, flood plains, meander bends, and sand bars. These landforms are continuously changing and vary in temporal scale (fig. 9). Some features take many years to evolve; others are formed over the course of a single large storm. Stream terraces are abandoned flood plains that formed when the stream flowed at a higher elevation than its present course and are no longer related to the modern flow regime. In the Kalamazoo River, these terraces were formed 13,500 to 16,000 years ago when most of the streamflow consisted of glacial meltwater from the Saginaw Lobe (Dorr and Eschman, 1970).

The flood plain is the area adjacent to a stream channel, which receives overflow water during storm events. As water enters the flood plain, it loses energy and deposits its sediment load. Heavier, coarser sediments tend to be deposited at the edge of the flood plain, immediately adjacent to the stream, whereas finer material settles out farther inland. These localized deposits of coarse material are often referred to as natural levees. The stage at which the streamflow meets the cusp between the stream channel and the flood plain is commonly referred to as the bankfull stage. This stage is commonly referred to as the "channel forming" stage because of its high frequency and its capacity to erode, transport, and deposit sediment.

As a stream channel evolves, it forms meander bends. Meander bends start out having a large radius, which over time becomes smaller as banks along their outer edge are eroded and point bars form along their inner edge. This combina- tion of erosion and deposition exaggerates the channel form until, during high flows, water is able to pass directly over the neck of the meander bend. These high flows facilitate the formation of a new channel across the meander, shortening the overall length of the stream channel. Over time, the meander becomes abandoned and leaves traces of where the river used to flow in the form of oxbow lakes and filled channels. As part of this study, many abandoned oxbows and channels were noted as locations of change along the Kalamazoo River. These features indicate historical changes in the river's morphology that provide evidence for the dynamics of the river.

One focus of concern in the Kalamazoo River has been the stability of its streambanks. Within the Plainwell to Otsego reach, unstable streambanks potentially act as a continuing source to the river of PCB-rich sediments held within the flood plain. By understanding the mechanisms behind bank failure, the susceptibility of the Kalamazoo River streambanks can be determined.

The failure of a streambank can have many underlying causes and can take one of various forms. Geotechnical properties of the sediment layers, over-steepening of the streambank, addition of loads to the top of the bank, saturation of the bank, and rapid drawdown of water levels adjacent to the bank can contribute to failure (Budhu, 2000). Banks can become over-steepened by the removal of material at the base, or bank toe, or by the lowering of the streambed adjacent to the bank (Amiri-Tokaldany and others, 2003; Osman and Thorne, 1988). The bank toe acts to support the overall bank; as the toe is removed the stream widens, making the bank angle steeper. All sediments have a critical angle of slope that is a function of their composition. Once the critical angle is exceeded, the sediments cannot support themselves; the result is a failure that establishes a new bank angle that is less than the critical angle.

Geotechnical properties of the sediments layers include cohesion, saturated unit weight, friction angle, critical shear stress, and erodibility. Fluids introduced into the pore spaces of the bank sediments can lead to failure by destabilizing the bank from within. Saturation and oversaturation of the sediments reduces the amount of cohesion and friction between the grains. This reduction allows for slippage between sediment grains, and increased likelihood of bank failure.

Modes of failure include movement of one mass of soil sliding over another (translational failure), displacement of a wedge-shaped mass of soil (wedge failure), displacement of a wedge-shaped mass of soil that has also been undercut (beam cantilever failure), and undercutting of the bank (tensile cantilever failure) (fig. 10; U.S. Navy, 1986; Easson and Yarbrough, 2002). 


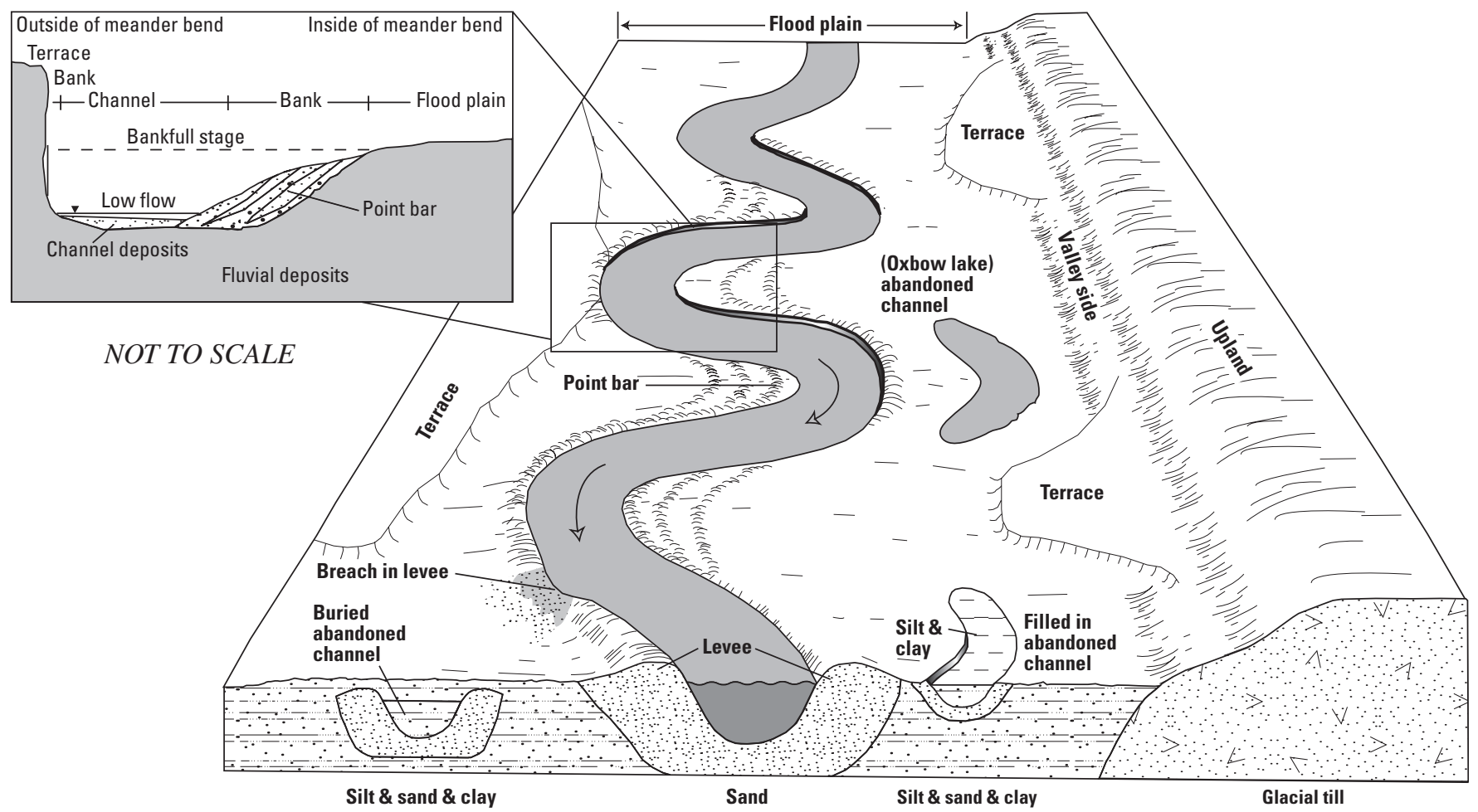

Figure 9. Common landform featuers related to streams (from Fitzpatrick and others, 1999)..

Before Failure

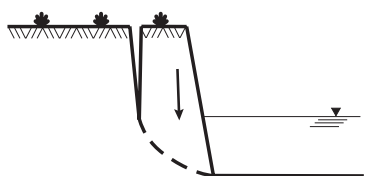

Translational failure

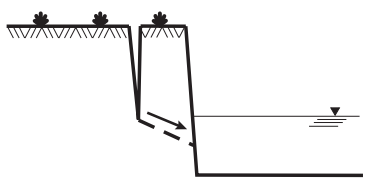

Slab failure (or wedge failure)

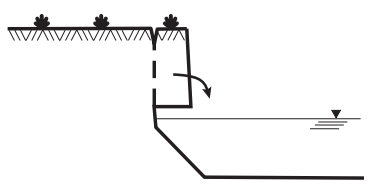

Beam cantilever failure

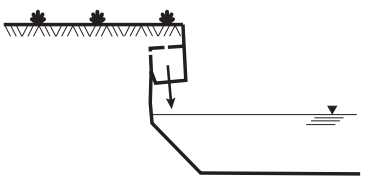

Tensile cantilever failure

Figure 10. Different modes of streambank failure (used with permission from Easson and Yarbrough, 2002).

\section{METHODS}

\section{Analysis of Historical Documents and Aerial Photographs}

To gain a qualitative perspective on the changes in channel width and position in the Kalamazoo River from the early to mid-1800s to the present (2003), historical multidate, General Land Office (GLO) survey notes and aerial photography were analyzed, in part through time transgressive comparison (a method that aids in understanding the fluvial system through visualization). Key features that can be noted from aerial photography include drainage patterns, erosion, and changes in vegetation, all of which can be useful in interpreting the characteristics of a stream channel (Howe, 1960).

The Michigan Natural Features Inventory digitized GLO survey notes into a land cover GIS dataset (Comer and others, 1998). The GLO data were collected on a statewide county-by-county basis and range in time from 1816 to 1856 . Although the surveyors' notes focused extensively on tree data, the location of rivers and lakes also was documented. Because of the uncertainty present in the interpretation of the notes, the application of this dataset was used with caution.

The aerial photography used in this analysis represented three time periods: 1938, 1981, and 1999. The 1938 and 1981 photographs were furnished by the Center for Remote Sensing and GIS Aerial Image Archive at Michigan State University as individual paper prints. The 1938 photographs were originally 
contracted by the U.S. Department of Agriculture (USDA) and taken by Edgar Tobin Aerial Surveys (presently Tobin International) of San Antonio, Tex. from June to October 1938. This photography was acquired at a scale of 1:20,000 $(1 \mathrm{in} .=1,666 \mathrm{ft})$. The 1981 photographs were originally contracted by the USGS as part of the National High Altitude Photography program (NHAP) and taken by Mark Hurd Aerial Surveys, Inc. of Minneapolis, Minn. in May 1981. The photography was acquired at a scale of 1:58,000 $(1 \mathrm{in} .=4,833 \mathrm{ft})$.

The original paper prints were scanned and saved as Tagged Image File Format (TIFF) images. The 1938 photography was scanned at a resolution of 510 dots per inch (dpi) and the 1981 photography at a resolution of 1,200 dpi for a resultant ground resolution of approximately $1 \mathrm{~m}$ for both sets of imagery.

Because no information could be obtained on the type of camera(s) used in the 1938 photography acquisition, these images could not be orthorectified by digital methods. Orthorectification allows errors produced during image processing to be reduced. It controls the amount of geometric distortion caused by the camera orientation, topographic relief of the photographed area, and systematic errors associated with the imagery (ERDAS, 2001). Additionally, a coordinate system is projected onto the image surface during the orthorectification process.

Orthorectification is possible from information obtained through a camera calibration report, which was not standard for imagery of that period. Camera calibration reports include information such as the focal length of the camera, radial lens distortion, position of the fiducial marks, and position of the principal point of the photograph. Although it is possible to orthorectify imagery without a calibration report, either the focal length of the camera or average flying height of the aircraft is a necessary component for this process. As an alternative to orthorectification, the 1938 imagery was georectified by means of geometric correction. Georectification is an acceptable alternative to orthorectification in this instance, because the terrain in the study area is not marked by large changes in relief.

Georectification assigns a real-world coordinate system to individual photographs and corrects distortions on the basis of generic, polynomial transformations (ERDAS, 2001). The 1938 photographs were individually georectified in ERDAS Imagine 8.5 by use of a second-order polynomial transformation. In order to relate the images to points of a known location, the analyst used ground-control points such as road intersections, hard structures, or, in some rare cases, natural features (trees or river bends). Ground-control points used in the georectification process were collected from 1998 Series USGS Digital Orthophoto Quadrangles (DOQ) from the Michigan Department of Natural Resources (MDNR) that matched the area of study. The source imagery was acquired at a scale of 1:40,000, with a reported accuracy of $+/-33 \mathrm{ft}$. During the ground-control point collection, the attempt was made to select at least nine evenly spaced ground-control points per image. Additionally, at least one checkpoint per image was collected to measure the accuracy of the geometric-correction model. To complete the georectification, the imagery was resampled by means of a nearest neighbor interpolation.

For the 1981 photography, camera calibration reports were obtainable from the Optical Science Lab (OSL) at the Mapping Application Center of the USGS, so the 1981 photography was able to be orthorectified by use of the ERDAS Imagine 8.5 Orthobase module. Ground-control points were collected from the same reference as the 1938 images. About 9 evenly spaced ground-control points were selected on each image, in addition to 50 tie points per image.

Tie points are points that are observable on one or more overlapping photographs but whose ground coordinates are unknown, but. The tie points serve to tie overlapping images together. Ground coordinates for the tie points are computed through a process called block triangulation, which uses the information from the camera calibration report and the ground-control-point locations. Two check points per image also were collected to measure the accuracy of the block triangulation. Once the block triangulation was done, the distortions from topography were corrected through a process called orthoresampling. This process is facilitated in Orthobase by matching the image pixels with a corresponding elevation pixel from a USGS 30-m digital elevation model (DEM) of the study area. The orthoresampling was completed by means of bilinear interpolation.

Once the 1938 and 1981 sets of imagery were georectified or orthorectified, the imagery was mosiacked together to produce a single image of the study area for each year. Both mosiacked images were then accuracy checked by use of the Federal Geographic Data Committee's (FGDC) National Standard for Spatial Data Accuracy (NSSDA) guidelines. In accordance with these guidelines, a minimum of 20 welldefined checkpoints were used to test the accuracy of the georectification and orthorectification processes (Federal Geographic Data Committee, 1998). These checkpoints were collected from a USGS 7.5-minute topographic quadrangle map in digital raster graphic (DRG) format, which was assumed to be a higher accuracy product than the resultant georectified and orthorectified imagery.

The accuracy of the 1938 georectified imagery is $+/-78 \mathrm{ft}$ at the 95 -percent confidence level. This accuracy does not meet the National Map Accuracy Standard (NMAS) for a 1:20,000-scale product. The positional errors in this dataset were likely because of the inability to correct for elevation in the georectification process and errors in the groundcontrol-point source data. Because the results of the georectification and orthorectification were to be used in a qualitative study, the errors of the 1938 imagery were not a major concern. The accuracy for the 1981 orthorectified imagery is $+/-77 \mathrm{ft}$ at the 95 -percent confidence level. This accuracy meets NMAS for a 1:58,000-scale product.

Aerial photography from 1938 and 1981 were acquired as individual paper prints and were prepared for use in a GIS using the procedure described above. Aerial photography 
from 1999 were furnished as an orthorectified, GIS-ready layer by Camp, Dresser, and McKee.

Features of the Kalamazoo River were digitized from the aerial photographs for each time period. Some limitations of the photography, such as poor contrast from the original prints and the vegetative cover at the time of the photograph, have introduced error into the interpretation of the streambank. However, because the intended purpose for the streambank digitizing was for qualitative comparison, these limitations were not of great concern. Streambanks and islands were digitized at a scale of 1:2,500 and were identified on-screen with ArcMap 8.2 (Minami, 2001).

\section{Longitudinal Profile Development}

A longitudinal profile was constructed for the entire length of the Kalamazoo River to identify relative variations in slope and potential reaches that are prone to erosion or deposition. Data for the longitudinal profile were gathered from contours and stream lengths measured manually with a planimeter from USGS 7.5-minute topographic quadrangle maps. The manually derived stream lengths and river miles were updated to correspond to GIS-derived river miles. A more detailed longitudinal profile for the Plainwell/Otsego reach (river mile 51.23 to 56.67) was derived from thalweg elevations extracted from valley cross-section data.

\section{Valley and Channel Cross-Section Data Collection and Aggregation}

Data for valley and channel cross sections were needed to support the bank-stability models and the ARS channel-evolution model (Wells and others, 2003). Cross-section data for the Plainwell/Otsego reach (river mile 51.23 to 56.67) were collated from four major sources: USGS cross-section surveys of the channel up to the edge of water on both banks, USGS bank-profile survey from channel bottom to flood-plain elevations, Blasland, Bouk and Lee, Inc. (BBL) valley and channel cross-section surveys, and USGS 7.5-minute topographic quadrangle maps. The USGS collected 98 channel cross sections in 2000-02 for the Plainwell/Otsego reach (Rheaume and others, 2002; 2003). The USGS channel cross-section data extended to the low-flow water surface. Sediment cores also were collected during the instream surveys to determine the elevation of the pre-dam channel bottom in the impounded reaches of the Kalamazoo River.

BBL collected 32 valley and instream cross-sections in 1993-94 in the Plainwell/Otsego reach (Blasland, Bouck, and Lee, Inc., 1994). These cross sections were used as a base to determine valley widths, channel location within the valley, and flood-plain, terrace, and valley-side elevations.

USGS channel cross-section data were combined with BBL cross-section data at 55 locations along the Plainwell/ Otsego reach (river mile 51.23 to 56.67). At the time of the field data collection, no USGS channel data were available for the reach downstream from the Otsego City Dam. For this portion of the reach, the BBL cross-section data were used.
Bank profiles for both banks along the main channel were surveyed in 2002 by the USGS at each of the combined USGS/BBL cross-section locations in the previously impounded reaches above the Plainwell and Otsego City Dams. In the braided portion of the reach downstream from the Plainwell Dam, some of the bank profiles of the secondary also channels were surveyed.

Endpoints of the valley cross-sections from combined the data sources were extended by use of elevations and distances measured from USGS 7.5-minute topographic quadrangle map, if needed. Data were added to a valley cross section from this source to ensure that the endpoint elevations were above any flood stages historically reached by the river. The resulting cross sections were used by the USDA-ARS for modeling sediment transport through the reach.

The valley cross-sections were used as a base to design a potential stable channel through the reach for simulation of the removal of the Plainwell and Otsego City Dams. For this study, a stable channel was considered to be one in which the sediment entering the reach is in equilibrium with that leaving the reach. The channel geometry, channel location, flood-plain area, and channel elevation were modified on the valley cross sections to minimize potential flooding, erosion, and sedimentation problems. USGS data from channel sediment cores were used to identify the pre-dam channel and flood-plain surface (Rheaume and others, 2002; 2003). In addition, the evaluation of historical channel planform was used to determine the best location for the designed channel. The shape and size of the designed channel and the flood-plain width were determined by examining reaches upstream from Plainwell and downstream from Otsego that are not presently or historically affected by impounded water or sediment. The resulting slope of the designed channel through the portion of the reach affected by impounded sediment is similar to the channel slope near the city of Plainwell and downstream from Otsego City dam. The HEC-RAS River Analysis System (Brunner, 2002) was used to route floods through the designed channel for bankfull and 2- and 50-year recurrence intervals (flow magnitudes of $1,700 \mathrm{ft}^{3} / \mathrm{s}, 2,900 \mathrm{ft}^{3} / \mathrm{s}$, and $6,300 \mathrm{ft}^{3} / \mathrm{s}$, respectively). The HEC-RAS simulation results for these flows were used to confirm that the designed channel was adequate for conveying bankfull flows and that the designed flood-plain area was adequate for safely conveying the 50-year flood.

\section{Streambank-Stability Assessment}

The present-day (2003) banks and flood plain of the study reach were once inundated by water impounded by the Plainwell and Otsego City Dams. Since the dewatering of the impoundments and subsequent removal of the superstructure of the Plainwell Dam, the Kalamazoo River has established a new base level by eroding into sediments that had served as the impoundment bottom. The surrounding banks contain concentrations of PCB and other contaminants (Roy F.Weston, Inc., 2002) and may be a continuing source of contaminants 
into the river. Part of the USGS study was to assess the permanence of these banks under present conditions and if the dams were removed. An understanding of the condition of the banks and the processes that would lead to failure of the banks would aid in the development of management criteria suitable for this location.

The model used in the streambank-stability assessment was the ARS Bank-Stability and Toe-Erosion Model, Static Version 3.4, designed by the ARS (Simon and others, 2003). The model is run in a Microsoft Excel-based environment and is subdivided into a toe-erosion module and a bank-stability module.

Each bank is analyzed individually and is described by inputting parameters such as the bank profile, mean bank angle $(\beta)$, layer thickness, and the elevation at which the shear surface emerges from the bank. By default, the model separates the bank profile into individual layers, leaving the user to define the thickness and geotechnical properties of each layer. If the bank is composed of a single homogeneous layer, the thickness is subdivided equally into five layers and the geotechnical properties are assigned uniformly throughout.

The model contains worksheets for the entry of geotechnical data related to each of the model layers. For the toe-erosion module, the geotechnical data inputs consist of the critical shear stress $\left(\tau_{c}\right)$ and erodibility $(k)$ coefficients for the bank and bank-toe materials. For the bank-stability module, the geotechnical data inputs consist of internal friction angle $\left(\phi^{\prime}\right)$, cohesion $\left(c^{\prime}\right)$, saturated unit weight $(\gamma)$, and rate of increase in soil shear strength due to matric suction $\left(\phi^{b}\right)$ (Simon and others, 2003). Values used in each of the models are presented in appendix B.

The model is a limit equilibrium model, and the end result is the calculation of a factor of safety $\left(F_{s}\right)$ for the bank under the user-defined hydrologic conditions. The $F_{s}$ is a ratio of the resisting forces and the driving forces and is based on the equations for the Mohr-Coulomb failure criterion for the saturated layers of the bank (Simon and Collison, 2002) and the Fredlund and others (1978) criterion for the unsaturated layers (Simon and others, 2000):

$$
F_{s}=\frac{\sum c^{\prime}{ }_{i} L_{i}+\left[S_{i} \tan \phi_{i}^{b}\right]+\left[W_{i} \cos \beta-U_{i}+P_{i} \cos (\alpha-\beta)\right] \tan \phi_{i}^{\prime}}{\sum W_{i} \sin \beta-P_{i} \sin [\alpha-\beta]}
$$

where $i$ represents the $i^{\text {th }}$ layer;

$L$ is the length of the failure plane within the layer;

$S$ is the force produced by matric suction on the unsaturated part of the failure surface;

$W$ is the weight of the layer;

$U$ is the hydrostatic-uplift force on the saturated portion of the failure surface;

$P$ is the hydrostatic confining force due to the river stage; and

$\alpha$ is the failure plane angle (Simon and others, 2000).

In the model, $F_{s}$ values less than 1.0 are considered to be unstable, values between 1.0 and 1.3 deemed conditionally stable, and values greater than 1.3 are considered to be stable.
The valley cross-section dataset described in the previous section provided the bank profiles and channel slope used in the model. Ten cross-section points were used to define the bank and bank-toe profiles. Bank angles were determined by taking the average bank angle from the top of the bank to the top of the bank toe.

Geotechnical bank data were collected within the study reach from April to November 2002. Data-collection locations (fig. 11) were chosen to coincide with locations of USGS and BBL transects. The geotechnical bank surveys consisted of a jet test, a borehole-shear test, and bulk-density and particlesize analysis. The jet test and borehole-shear test are two in-situ tests designed to determine geotechnical properties specific to the test location.

A full description of the jet-test apparatus and a discussion of the procedure used for data collection is presented in Hanson and Simon (2001). The jet test yields the $\tau_{c}$ and $\mathrm{k}$ input parameters for the toe-erosion module of the model. Data collected from the borehole-shear test enable the $\phi$ ' and $c$ ' to be determined. Handy and Fox (1967) and Thorne and others (1981) describe the apparatus and procedure for data collection.

Hydrologic data used in the model consist of river stage and water-table elevation. Because the emphasis is on the potential for bank failure, the critical hydrologic conditions necessary for failure were used. For the toe-erosion module, the stages used at each bank-assessment location consisted of maximum water-surface elevations under present and flood conditions. By using the maximum stage elevations, the model biases its prediction in favor of the largest amount of possible erosion for that particular combination of stage, duration, and bank material. The streambank's post-erosion geometry is output from the toe-erosion module and serves as the input for the bank-stability module.

In the bank-stability module, the minimum water-surface elevations predicted by another model were used, and the water-table elevation was placed at or near the top of the bank immediately adjacent to the river in order to oversaturate the bank. Oversaturation would result in excess pore-water pressures, decreasing bank stability.

Water-surface elevations at each bank location were based on the results of a one-dimensional sediment transport model, SEDMOD, by USGS (Syed and Bennett, 2004). SEDMOD was used to determine the erosion and transport of sediments through a reach of Kalamazoo River between the Plainwell and Allegan stream-gaging stations under present and flood conditions. The present conditions used in the SEDMOD model reflect the streamflow measured at the Kalamazoo River at Plainwell stream-gaging station for a 730-day period from January 1, 2001 to December 31, 2002 (fig. 12). The flood conditions used in the SEDMOD model reflect the streamflow measured at the Kalamazoo River at Comstock and Kalamazoo River near Fennville stream gaging stations for a 60-day flood period in spring 1947 (fig. 12). The flood-conditions model scenario also included the hypothetical removal of the Plainwell and Otsego City Dams. 


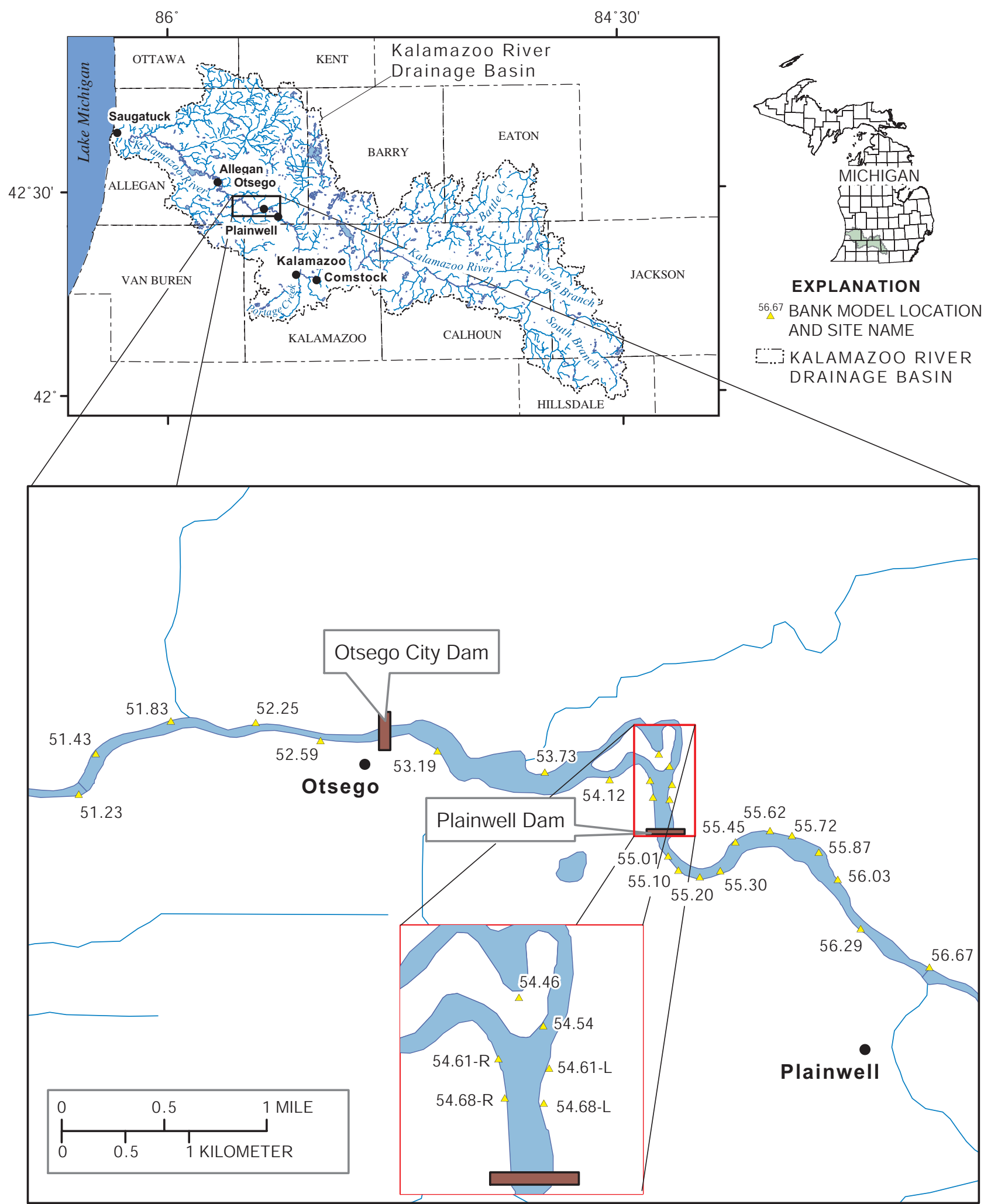

City names and locations from U.S. Geological Survey digital raster graphics. Hydrologic divides from Michigan Department of Environmental Quality Land and Water Management. Hydrologic features and county boundaries from

Figure projection is Hotine Oblique Mercator, Type 2, Scale factor at the projection's center 0.9996; longitude of the projection's center $860000 \mathrm{~W}$; latitude of the projection's Michigan Resource Information System.

Figure 11. Location of bank models on the Kalamazoo River, Michigan. 

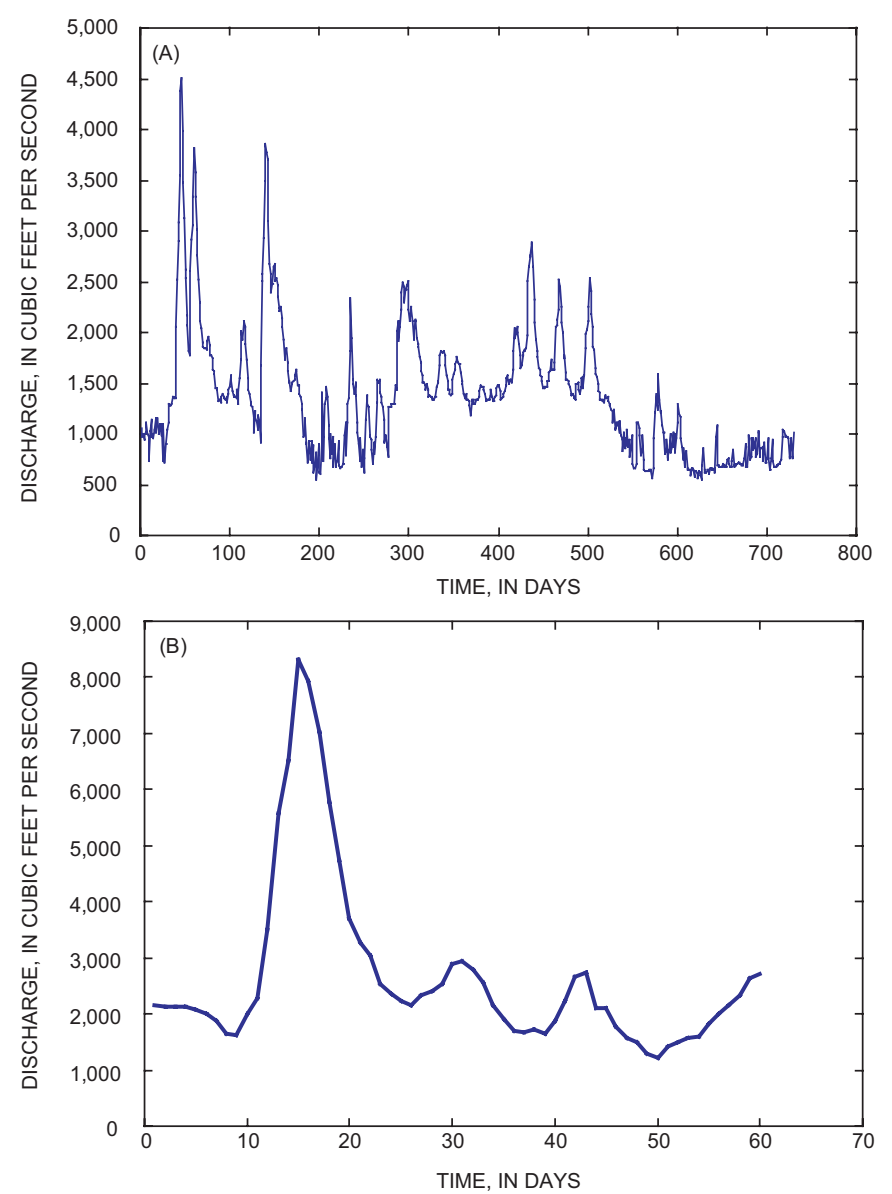

Figure 12. Flow rates used in SEDMOD sediment transport model under (A) 2001-02 flow conditions and (B) 1947 spring flood conditions with dams removed, Kalamazoo River, Michigan.

Channel slopes were interpreted from the valley crosssection data for the present-conditions bank assessments. To remain consistent with the input water-surface elevations under flood conditions, the channel slopes used in the floodconditions bank assessments were based on the SEDMOD bed-elevation results. The modeled reach was broken up into subsections, and the slopes used are summarized in table 1.

Table 1. Slopes used in bank-stability assessment for present and dams-removed scenarios, Kalamazoo River, Michigan

\begin{tabular}{ccc}
\hline River mile & $\begin{array}{c}\text { Present- } \\
\text { conditions } \\
\text { slope }\end{array}$ & $\begin{array}{c}\text { Dams- } \\
\text { removed } \\
\text { slope }\end{array}$ \\
\hline $56.67-55.72$ & 0.0008 & 0.0009 \\
$55.72-55.2$ & .0015 & .0016 \\
$55.2-54.93$ & .0002 & .0009 \\
$54.8-54.54$ & .0032 & .0032 \\
$54.54-53.22$ & .0003 & .0001 \\
$52.59-51.23$ & .0005 & .0010 \\
\hline
\end{tabular}

In the bank-stability module, the user has the ability to specify varying vegetative cover, which may affect bank stability. By default, the model calculates the $F_{s}$ without vegetative cover. For the models developed in this study, each bank was assessed without vegetative cover and with covers of eastern cottonwood, gamma grass, switch grass, sycamore, and black willow.

\section{HISTORICAL AND SIMULATED CHANGES IN CHANNEL CHARACTERISTICS}

\section{Channel Planform Changes from 1830s to 1999}

Comparison of streambanks interpreted from 1830s GLO surveys and digitized from 1938, 1981, and 1999 aerial photography shows that the Kalamazoo River has not been prone to appreciable lateral migration. For brevity, the results of changes in channel characteristics described in this section describe changes observed and do not describe the Kalamazoo River on a river-mile-to-river-mile basis.

Most of the observed changes can be attributed to channel shortening by cutting across meander bends, or to human influences such as channelization or the construction of impoundments on the river. An example of a developing meander bend is shown in appendix $\mathrm{C} 1$. From river miles 9.5 to 10.5 , the neck of land between the river bends became narrower from the 1830s to 1999. Numerous bends throughout the reach analyzed showed a similar trend. In some cases, the aerial photographs show oxbow lakes and filled channels adjacent to the river.

Movement and channelization of the mouth of the Kalamazoo River was observed in this analysis. As shown by streambanks interpreted from the early to mid-1800s GLO survey notes, the historical course of the Kalamazoo River moved along a wide bend as it emptied into Lake Michigan (appendix C2). In 1904, the bend was altered so that the river mouth was moved to its present-day course, approximately $0.75 \mathrm{mi}$ northwards and the channel was straightened (W.F. Baird and Associates, 1999).

Dams built on the Kalamazoo River, which include the Caulkins Dam, Allegan City Dam, Trowbridge Dam, Otsego Dam, Otsego City Dam, and Plainwell Dam, are shown in figure 2. Caulkins Dam was built in 1935 (J. Bernier, Consumers Energy, oral commun., 2003) and is upstream from Swan Creek Marsh at river mile 26.25. This impoundment is known as Lake Allegan and backs up water to river mile 33. Streambanks interpreted from the GLO surveys show that the former channel meandered within the banks of the presently impounded area (appendix C3).

Upstream from Lake Allegan, the Kalamazoo River passes through the city of Allegan. The Allegan City Dam is located within the city at river mile 36 . This dam was originally built in 1840 for hydromechanical use (J. Bernier, Consumers Energy, oral commun., 2003). The dam presently impounds water three-quarters of a mile upstream.

The Trowbridge Dam is at river mile 45 and was built in 1898 (Dalrymple, 1972). When the impoundment was at its 
full height, its backwaters extended upstream to river mile 49. The water level within the impoundment was lowered in 1973 (Anderson, 1991), resulting in a decrease in the area inundated. The present impoundment area extends upstream to river mile 47.25 (appendix $\mathrm{C} 4$ ). The lowering of the impoundment head has led to the exposure of various islands within a 1-mi stretch directly upstream from the dam that was previously mapped as a single straight channel in the GLO surveys. These islands are readily inundated at high flows. Within this island area, Rheaume and others (2000) found 7- to 11-ft thick layers of the fine-grained sand/silt/clay material that is associated with the PCB contamination.

At the edge of the former Trowbridge impoundment backwater (river mile 49), a channel meander was cut off once the impoundment head was lowered. When the impoundment was at its original height, the land encompassed by this meander was transformed into an island. Although this island is still visible in the 1999 aerial photographs, a recent (2003) field reconnaissance indicated that the channel surrounding the island is no longer active.

The Otsego Dam is at river mile 49.5. This dam was built in 1902 (Dalrymple, 1972), and, similar to Trowbridge, the head on the impoundment was lowered in 1973 (Anderson, 1991). The GLO survey notes show that the original course of the river was to the right of the present spillway. The present impoundment backwater extends $1.75 \mathrm{mi}$ upstream, just below the M-89 bridge (appendix C5). Originally, the inundated area was larger, yet the backwater extended only $0.25 \mathrm{mi}$ further upstream than it currently (2003) does. Comparison of the GLO survey notes with the 1938 aerial photography shows that the river channel has been shifted slightly (river mile 49.75 to 50.25) and that the confluence with Pine Creek has been moved downstream about $500 \mathrm{ft}$ (river mile 50.5). Pine Creek is currently impounded by a small wetland control structure. The backwater created by this structure inundates an area similar to what the Otsego Dam used to flood when it was at its full height (appendix C5). The Pine Creek impoundment was dewatered for a short period in 2000 in order to flush out sediment (Dennis Eagle, Michigan Department of Environmental Quality, oral commun., 2000); recent observations show that the previous water levels have been reestablished.

The Otsego City Dam is at river mile 53. Originally built in 1835 (Nevins and Dalrymple, 1975), the GLO survey notes show that an island was at the site of the present-day dam. The 1938 aerial photographs show a bypass to the south of the dam (appendix C6). This bypass was filled in 1957, and a low area along the city riverfront marks its location.

The Plainwell Dam is at river mile 54.9. Within the 1.75-mi distance between the Otsego City and Plainwell Dams lies the most complex portion of the Kalamazoo River. This reach is characterized by an anastomosing channel because the river splits into multiple channels below the dam and the Gun River enters the Kalamazoo River (river mile 53.5). A comparison of the aerial photography shows that the water levels behind the Otsego City impoundment were increased in 1981 and were lowered by 1999 . Through the impounding of the
Kalamazoo River and adjustment of water levels, the mouth of the Gun River has been extended close to $1800 \mathrm{ft}$ downstream from its location shown as the GLO surveys.

Upstream from the Plainwell impoundment, a comparison of the 1999 aerial photographs with the GLO survey notes reveals that the present-day planform of the river closely matches that of the mid-1800s. The 1938 aerial photographs show that the spillway for the Plainwell Dam released water to the west of the present spillway and that the edge of the impoundment backwater when the dam was in full operation extended 1.6 mi upstream to river mile 56.5 (appendix C7). A number of islands formed at this location from sediment being deposited as the water velocities slowed when going into the impoundment. The present impoundment extends to river mile 55.8 and has similar islands marking its edge.

In the $1880 \mathrm{~s}$, a millrace was dug and a diversion structure was built, diverting water from the Kalamazoo River and forming an island on which the city of Plainwell was built (river miles 56.7-58.3). In order to provide a new route for water that passed through the diversion structure, a bend was formed in the Kalamazoo where the GLO survey notes show a straight channel had been (appendix C8). The reach along this bend forms the main channel of the river.

Meander bends that had been cut off prior to the GLO surveys can be seen at river miles 60.5-61 (appendix C9) and 64.5. Other observations include a bend cutoff at river miles 71.8-72.2 between the time period of the 1938 and 1981 aerial photographs, and a meander bend cut off at river mile 75 between the time period of the GLO surveys and the 1938 aerial photographs.

Built in 1941, Morrow Dam is at river mile 76.4 (J. Bernier, Consumers Energy, oral commun., 2003). The backwater in this impoundment extends upstream to river mile 79.4. The GLO surveys and 1938 aerial photographs show that this impoundment inundates a reach consisting of many bends (appendix C10). Comparisons between these two sources of data show changes in which the channel has shifted as the river meandered.

Overall, the large-scale changes in the course of the Kalamazoo River can be attributed to the placement of dams. The comparison of aerial photography to the GLO surveys within the impoundment areas indicated that as the impoundment heads were established, the river responded by inundating its banks and creating backwater. Downstream from each dam, the river returned to what is believed to be its pre-dam character: a fairly straight, gravel bottom, steep-sloping channel. In the case of the Plainwell Dam, the river flows almost immediately into the backwater of the Otsego City Dam and the river is not able to reestablish its original form. The lowering of water levels and removal of the dam superstructure within the Plainwell impoundment caused sediment to erode from the impoundment and fill in the main channels of the anastomosed reach immediately downstream. This reach formed new channels and shifted the location of the main channel southwards (appendix C6; Rheaume and others, 2003). 


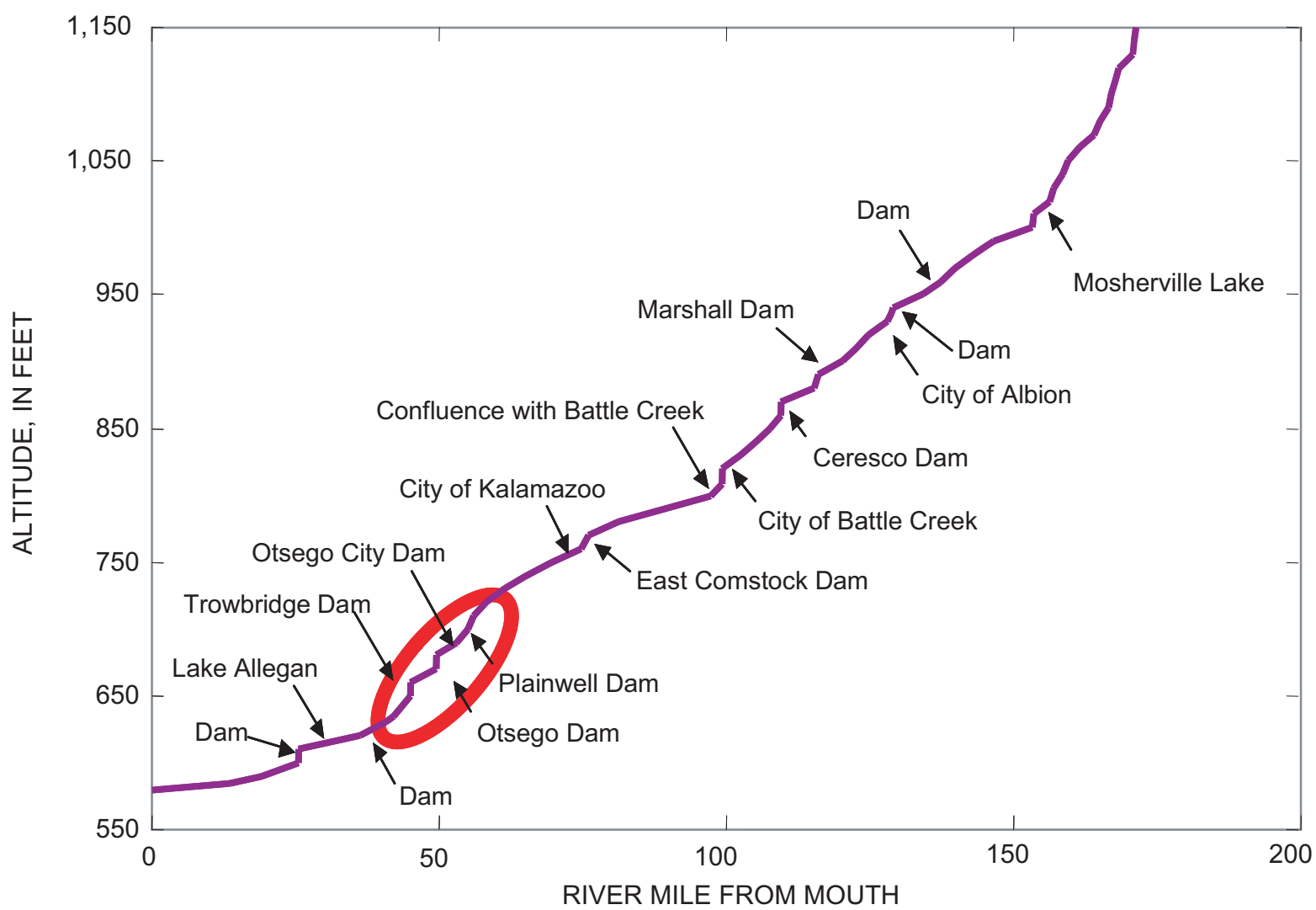

Figure 13. Longitudinal profile of the Kalamazoo River, Michigan, from its headwaters to mouth at Lake Michigan. Locations of dams within study area are highlighted in red.

\section{Longitudinal Profiles}

The longitudinal profile for the entire length of the Kalamazoo River is a reflection of two major factors: glacially related landforms and the presence of dams (fig. 13). The steep profile and average slope of 0.016 of the headwater reach upstream from Mosherville Lake (river mile 152) reflects drainage from the Tekonsha moraine. Downstream from Mosherville Lake (river mile 152 to 60) the average slope is 0.0006 . From river mile 60 to 40, a distance that includes the Plainwell/Otsego reach, the slope steepens to an average of 0.001 as the river cuts through the outer Valparaiso Moraine and associated outwash deposits. Rapids were present at Otsego prior to the construction of the Otsego City Dam (Dalrymple, 1983). The slope flattens as the Kalamazoo River nears its mouth at Lake Michigan (about 0.0001). Steeper slope and mid-profile position of the Plainwell/Otsego reach (river mile 51.23 to 56.67) indicate that the reach originally functioned as a zone of sediment and water transfer. The building of the dams has changed this reach from a transfer zone into a zone of sedimentation, with localized scour below the dams.

\section{Valley Cross Sections}

Valley cross-section locations for the Plainwell/Otsego reach (river mile 51.23 to 56.67) are shown in figure 14. The cross-section labels reflect the river mile at which the cross section is located. Valley cross-section diagrams for present conditions (2001-02) with the two dams are in appendix A. An example of data sources for the cross-sections is shown for cross section 54.41 in figure 15. This cross section is in the braided section of the river below the Plainwell Dam and is one of the most complex cross sections, with a main channel and three side channels. How the different data sets were combined is illustrated in figure 15 , with coarse points having been derived from the USGS 7.5-minute topographic quadrangle maps and consultant cross sections, and the more detailed points obtained by combining the USGS bank surveys and instream sounding and coring data.

Valley cross sections with a designed channel for the dams-removed scenario are shown in appendix A. The channel geometry, channel location, flood-plain area, and channel elevation were modified to minimize potential flooding, erosion, or sedimentation problems. Examples of how two cross sections were modified are shown in figure 16.

For the reach upstream from the Plainwell Dam, cross sections from river mile 55.33 to 56.67 (fig. 14) were not modified because they are upstream from impoundment effects 


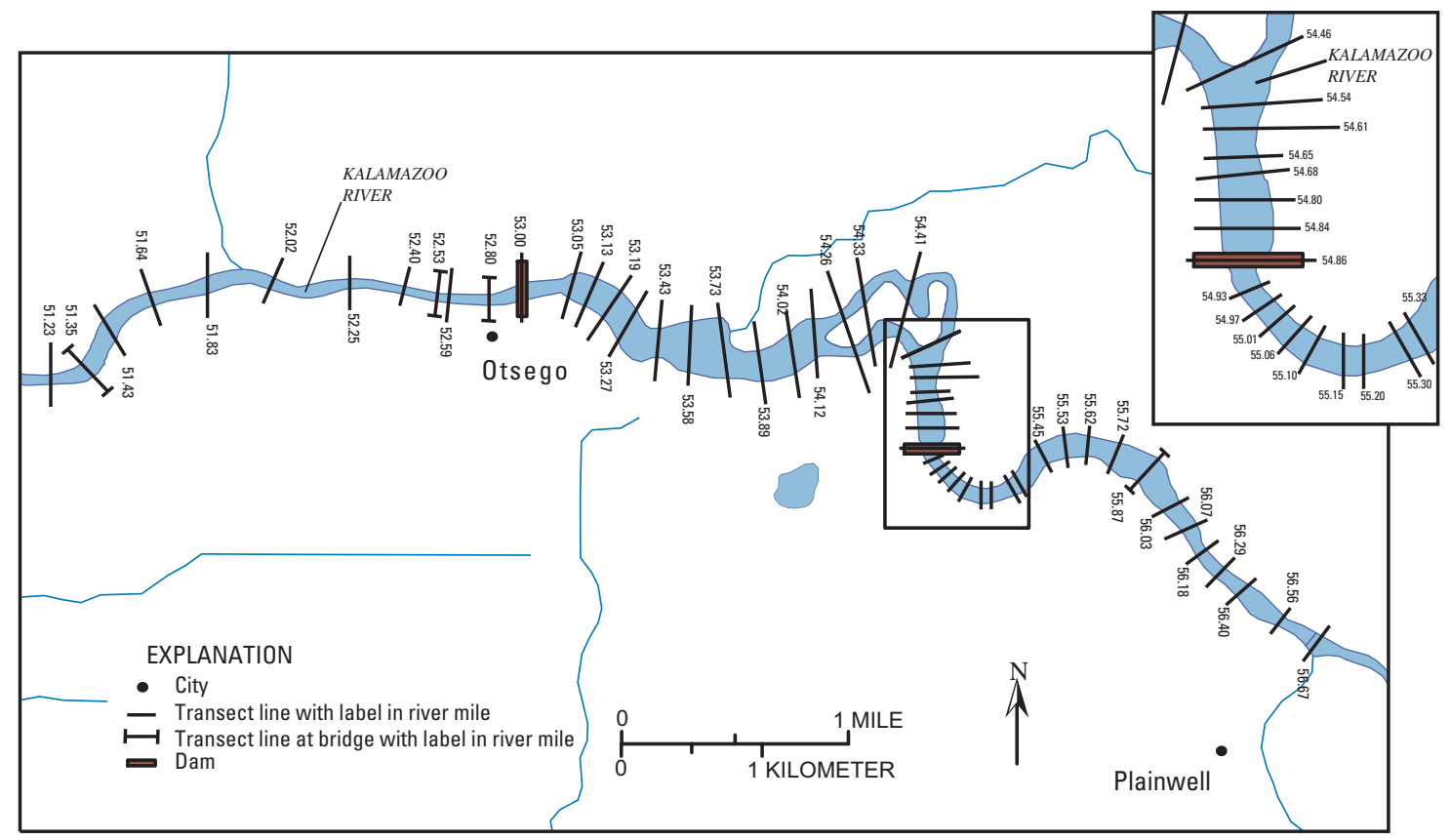

City names and locations from U.S. Geological Survey digital raster graphics.

Hydrologic divides from Michigan Department of Envirnmental Quality Land and Water Management.

Hydrologic features from Michigan Resource Information System.

Figure 14. Locations of valley cross sections in the Plainwell to Otsego reach of the Kalamazoo River, Michigan.

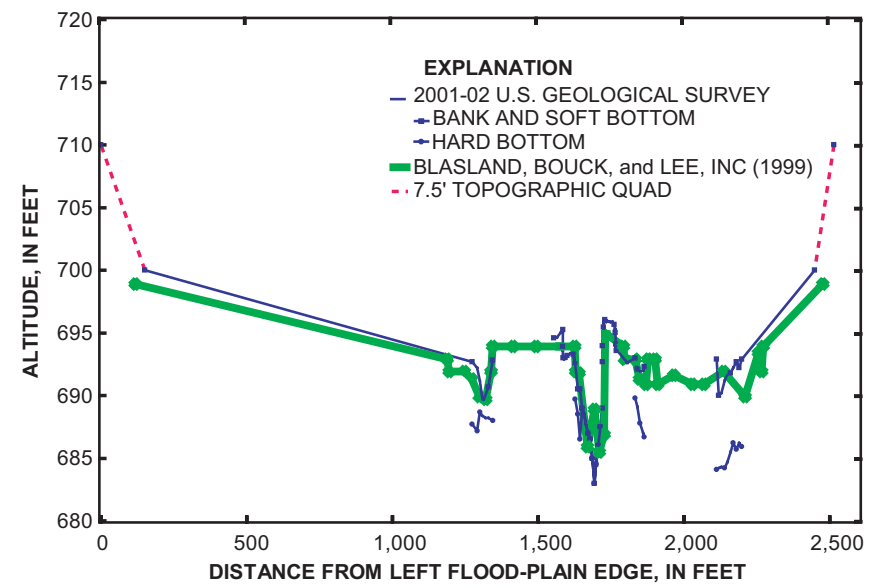

Figure 15. Example cross section of the Kalamazoo River Valley, Michigan.

(appendix A). Cross sections in the impounded area upstream of Plainwell Dam, from river mile 54.93 to 55.30, were mainly modified by lowering the channel to its pre-dam elevation and removing impounded sediment to increase flood-plain area (appendix A). The slope through this reach is similar to that for pre-dam conditions (fig. 17).

Between the Plainwell and Otsego City Dams from river mile 53.00 and 54.84 , the slope of the designed channel is steeper than that for pre-dam conditions (fig. 17). The pre-dam steepening of the slope at the former rapids near the City of Otsego was smoothed by slightly steepening the reach upstream from the Otsego City Dam location. In the braided part of the reach immediately downstream from the Plainwell Dam, the valley cross sections were modified by simplifying the multiple channel system into one or two main channels and relocating the main channels to those shown on the GLO survey (appendix C6). Modifications at cross section 54.41 are an example of typical changes made in the cross sections through this part of the reach (figs. 16 and 18). The planform of the designed channel is shown in figure 18.

Downstream from the multichannel reach from river mile 54.12 to 53.05, the channel elevation was lowered and impounded sediment removed to create a flood-plain area. Changes made to cross-section 53.05 are shown in figure $16 \mathrm{~B}$ as an example of the type of changes that were made to the cross sections in this reach. The channel location reflects that shown on the GLO survey (appendix C6).

Downstream from the Otsego City Dam from river mile 52.59 to 51.23 , cross sections were not modified, and present (2001-02) cross sections were used for the design channel (appendix A). The channel location has remained the same through this reach for the last 170 years (appendix C6).

Simulated HEC-RAS water-surface profiles for bankfull flow $\left(1,700 \mathrm{ft}^{3} / \mathrm{s}\right)$ and floods with 2 - and 50-year recurrence intervals (2,900 and 6,300 $\mathrm{ft}^{3} / \mathrm{s}$, respectively) are shown in figure 19. Present bridges are shown in the profile of water surfaces, with the top of the vertical lines representing the elevation of bridge decks. The designed channel cross-section is hydraulically stable. However, a 50-year flood overtops the Farmer Street Bridge, and the elevation of the 2-year flood is only about $1 \mathrm{ft}$ below the bridge deck. Presently, the Otsego 


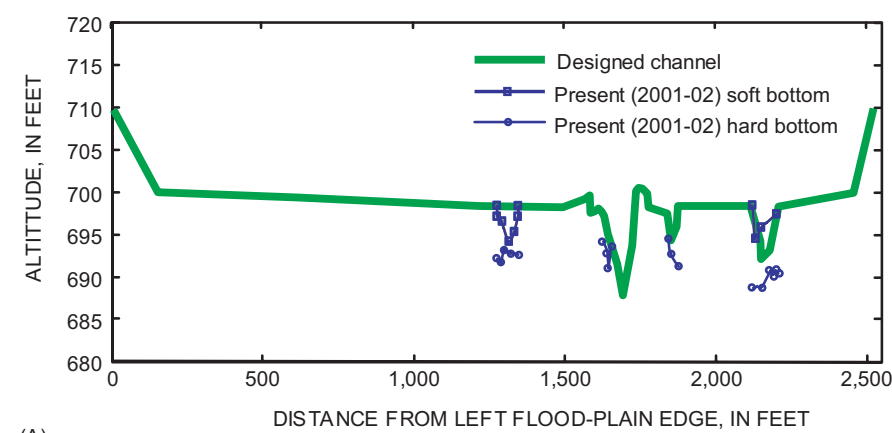

(A)

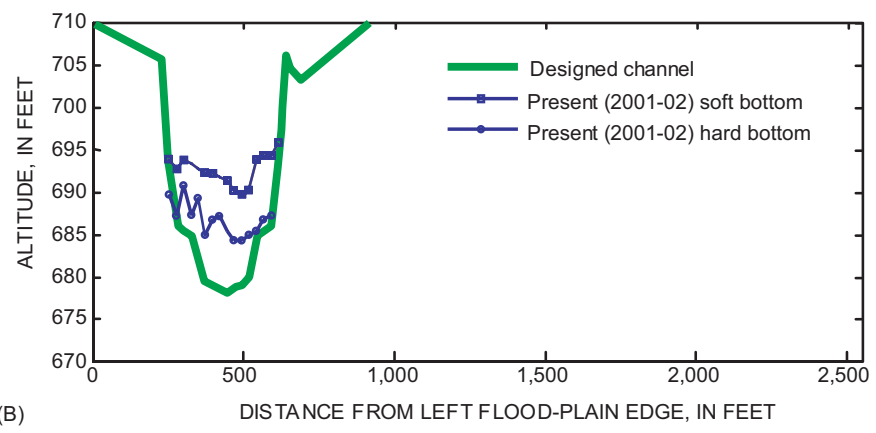

Figure 16. Cross sections 54.41 (A) and 53.05 (B) for present (2002) conditions and designed channel with dams removed, Kalamazoo River, Michigan.

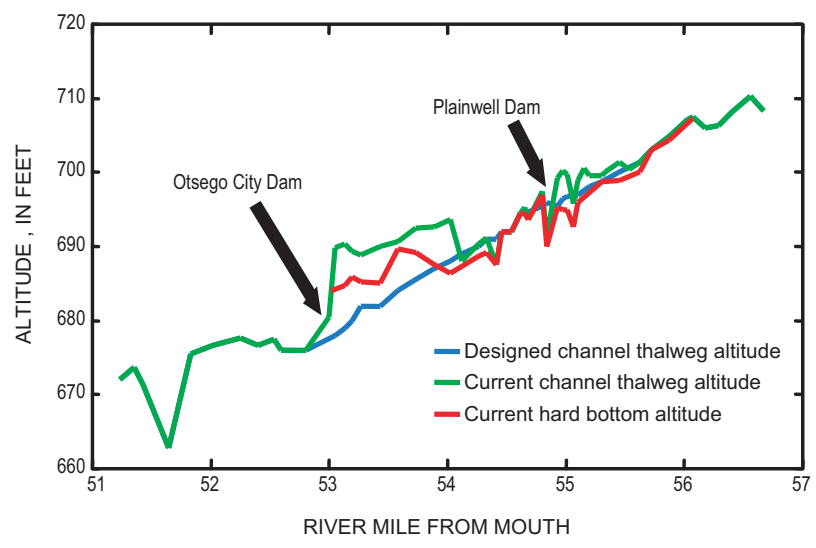

Figure 17. Longitudinal profile of present thalweg, present hard bottom lowest elevation, and designed channel thalweg in the Plainwell to Otesgo reach of the Kalamazoo River, Michigan.

City Dam must regulate flood flows enough to control flooding at this bridge. The relative elevation of the Farmer Street bridge deck above the Kalamazoo River channel is about $10 \mathrm{ft}$, compared to more than $20 \mathrm{ft}$ for the Highway 131 Bridge, $15 \mathrm{ft}$ for the North Street Bridge, and $12 \mathrm{ft}$ for the M-89 Bridge (fig. 19).

\section{Streambank Stability}

Data collected by Roy F. Weston, Inc. (2002) showed that the surrounding banks contain PCB and other contaminants.

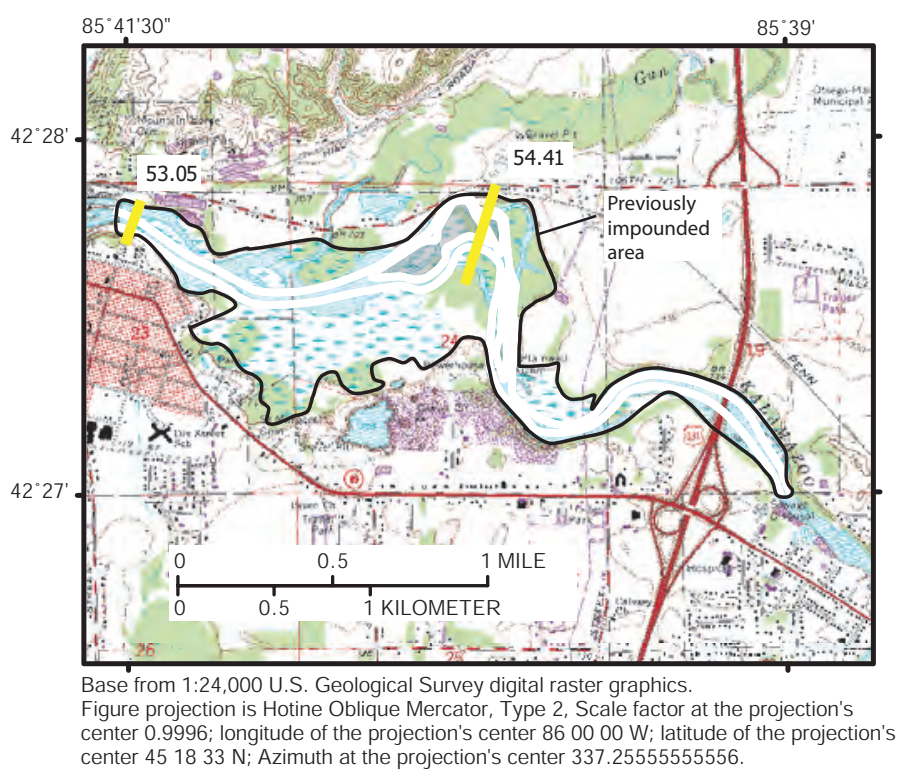

Figure 18. Planform of designed channel and approximate area with impounded sediment, Kalamazoo River, Michigan (cross sections 53.05 and 54.41 are indicated for reference.

Failure of these banks may become a continuing source of contaminants to the Kalamazoo River. A streambank stability model was used at selected locations in order to gain an understanding of the condition of the streambanks and the processes that would lead to their failure. The model was run under two scenarios: "present conditions," where the stage is consistent with the SEDMOD model stage elevations for a 730-day period from January 1, 2001 to December 31, 2002; and "flood conditions," where the stage is consistent with the SEDMOD 60-day spring flood model (Syed and Bennett, 2004).

Under present conditions, the bank-stability model calculated a factor of safety that would classify 8 of the 25 streambanks unstable and 3 of the 25 streambanks conditionally stable if there were no vegetation (table 2). Four of the unstable bank locations are located upstream from the Plainwell Dam; four of the unstable or conditionally stable bank locations are located between the Plainwell and Otsego City Dams; and two of the unstable or conditionally stable bank locations are located downstream from the Otsego City Dam. With vegetation considered in the model, the factor of safety became stable or conditionally stable at two of the unstable locations, the conditionally stable locations remained conditionally stable, and the stable locations remained stable for all vegetation types but black willow.

Toe erosion was occurred at all bank locations except cross-sections 55.2, 55.1, 55.01, 54.12, and 53.73 (fig. 11). At 7 of the 8 unstable sites, the low factor of safety can be attributed to toe erosion.

Under flood conditions, the bank-stability model calculated a factor of safety that would classify 7 of the 25 streambanks unstable and 4 of the 25 streambanks conditionally stable if there were no vegetation (table 3). All 7 of the unstable 


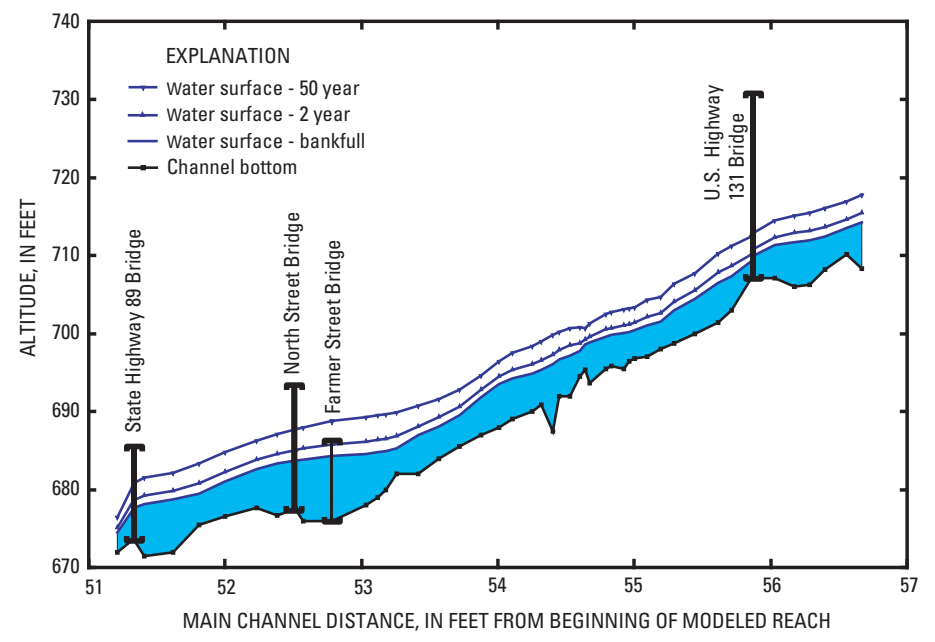

Figure 19. Water surface profiles for the HEC-RAS simulation of bankfull flood and floods in the design channel with 2- and 50 -year recurrence interval Kalamazoo River, Michigan. banks under flood conditions were predicted to be unstable under the present conditions. Locations 55.1 and 55.01 were predicted to be conditionally stable under flood conditions, but were predicted to be stable under present conditions; locations 54.68-L and 54.46 were predicted to be conditionally stable under flood conditions, but were predicted to be unstable under present conditions.

The effects of steepening the slope on the streambanks can be seen when comparing the results of the bank-stability assessment. Under present conditions, toe erosion resulted in undercut bank profiles. Field observations show that many of the locations analyzed were in the process of becoming undercut (fig. 20). The progression of bank undercutting would lead to the eventual localized failure of the bank as more sediment was removed (fig. 21). Once failure occurs, the bank material that is sloughed into the river acts to temporarily reinforce the bank and becomes part of the new bank toe (fig. 22). Over time, the root mass shown on top of the failed bank in figure

Table 2. Factor of safety predicted by bank-stability model under present conditions', Kalamazoo River, Michigan. [All data are dimensionless; factors of safety is computed by use of the ARS Bank-stability and Toe-Erosion Model (Simon and others, 2003). Values less than 1.0 are considered to be unstable, values between 1.0 and 1.3 deemed conditionally stable, and values greater than 1.3 are considered to be stable]

\begin{tabular}{|c|c|c|c|c|c|c|c|}
\hline & \multirow[b]{2}{*}{ Station } & \multicolumn{6}{|c|}{ Bank vegetation } \\
\hline & & None & Cottonwood & Gamma & Switch grass & Sycamore & Black Willow \\
\hline \multirow{11}{*}{ 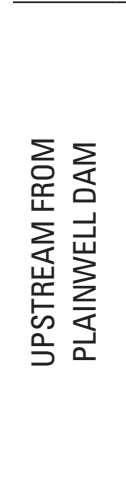 } & 56.67 & 2.01 & 4.30 & 3.97 & 7.91 & 4.00 & 2.50 \\
\hline & 56.29 & 1.45 & 1.46 & 1.45 & 1.45 & 1.46 & 1.46 \\
\hline & 56.03 & 8.69 & 13.94 & 13.21 & 22.27 & 13.23 & 9.68 \\
\hline & 55.87 & 4.78 & 6.65 & 6.20 & 9.04 & 6.41 & 5.23 \\
\hline & 55.72 & .55 & 1.81 & 1.47 & 3.32 & 1.66 & .90 \\
\hline & 55.62 & .83 & 1.12 & 1.05 & 1.50 & 1.09 & .90 \\
\hline & 55.45 & 1.30 & 2.72 & 2.41 & 4.63 & 2.54 & 1.66 \\
\hline & 55.3 & .20 & 1.35 & 1.07 & 2.80 & 1.21 & .50 \\
\hline & 55.2 & .01 & 5.24 & 4.13 & 12.35 & 4.59 & 1.35 \\
\hline & 55.1 & 1.89 & 3.14 & 2.88 & 4.85 & 2.98 & 2.18 \\
\hline & 55.01 & 2.58 & 5.29 & 4.64 & 8.78 & 4.95 & 3.24 \\
\hline \multirow{9}{*}{ 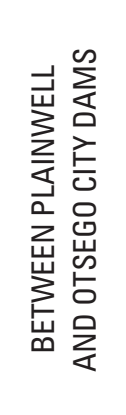 } & 54.68-L & .02 & .09 & .02 & .02 & .09 & .09 \\
\hline & 54.68-R & 4.77 & 4.60 & 4.77 & 4.77 & 4.60 & 4.60 \\
\hline & 54.61-L & 4.98 & 4.71 & 4.98 & 4.98 & 4.71 & 4.71 \\
\hline & 54.61-R & 1.08 & 1.08 & 1.08 & 1.08 & 1.08 & 1.08 \\
\hline & 54.54 & .12 & .15 & .12 & .12 & .15 & .15 \\
\hline & 54.46 & .96 & .97 & .96 & .96 & .97 & .97 \\
\hline & 54.12 & 2.21 & 2.22 & 2.21 & 2.21 & 2.22 & 2.22 \\
\hline & 53.73 & 3.88 & 3.88 & 3.88 & 3.88 & 3.88 & 3.88 \\
\hline & 53.19 & 2.54 & 2.51 & 2.54 & 2.54 & 2.51 & 2.51 \\
\hline \multirow{5}{*}{ 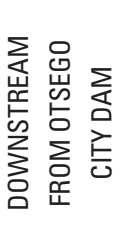 } & 52.59 & 3.28 & 3.25 & 3.28 & 3.28 & 3.25 & 3.25 \\
\hline & 52.25 & 1.24 & 1.23 & 1.24 & 1.24 & 1.23 & 1.23 \\
\hline & 51.83 & 1.91 & 1.90 & 1.91 & 1.91 & 1.90 & 1.90 \\
\hline & 51.43 & 1.41 & 1.40 & 1.41 & 1.41 & 1.40 & 1.40 \\
\hline & 51.23 & 0.79 & 0.87 & 0.79 & 0.79 & 0.87 & 0.87 \\
\hline
\end{tabular}

'Present conditions refers to wher 
Table 3. Factor of safety predicted by bank-stability model under flood conditions ${ }^{1}$. [All data are dimensionless; factors of safety is computed by use of the ARS Bank-stability and Toe-Erosion Model (Simon and others, 2003). Values less than 1.0 are considered to be unstable, values between 1.0 and 1.3 deemed conditionally stable, and values greater than 1.3 are considered to be stable]

\begin{tabular}{|c|c|c|c|c|c|c|c|}
\hline \multirow{2}{*}{\multicolumn{2}{|c|}{ River mile }} & \multicolumn{6}{|c|}{ Bank vegetation } \\
\hline & & None & Cottonwood & $\begin{array}{l}\text { Gamma } \\
\text { grass }\end{array}$ & Switch grass & Sycamore & Black Willow \\
\hline \multirow{11}{*}{ 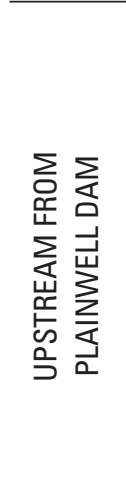 } & 56.67 & 1.83 & 2.87 & 2.73 & 4.51 & 2.73 & 2.06 \\
\hline & 56.29 & 1.54 & 1.55 & 1.54 & 1.54 & 1.55 & 1.55 \\
\hline & 56.03 & 4.72 & 6.52 & 6.25 & 9.32 & 6.28 & 5.06 \\
\hline & 55.87 & 7.97 & 14.67 & 13.11 & 23.39 & 13.82 & 9.59 \\
\hline & 55.72 & .74 & 1.95 & 1.62 & 3.38 & 1.81 & 1.09 \\
\hline & 55.62 & .83 & 1.11 & 1.04 & 1.46 & 1.07 & .90 \\
\hline & 55.45 & 1.52 & 3.09 & 2.76 & 5.25 & 2.89 & 1.91 \\
\hline & 55.3 & .28 & 1.46 & 1.17 & 2.95 & 1.32 & .59 \\
\hline & 55.2 & .22 & 5.08 & 4.04 & 11.69 & 4.47 & 1.45 \\
\hline & 55.1 & 1.01 & 1.33 & 1.26 & 1.77 & 1.29 & 1.08 \\
\hline & 55.01 & 1.10 & 1.37 & 1.32 & 1.77 & 1.33 & 1.15 \\
\hline \multirow{9}{*}{ 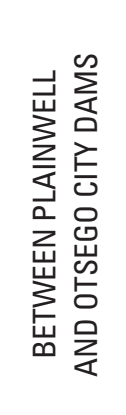 } & 54.68-L & 1.06 & 1.15 & 1.06 & 1.06 & 1.15 & 1.15 \\
\hline & 54.68-R & 3.06 & 2.98 & 3.06 & 3.06 & 2.98 & 2.98 \\
\hline & $54.61-\mathrm{L}$ & 1.32 & 1.32 & 1.32 & 1.32 & 1.32 & 1.32 \\
\hline & $54.61-R$ & 3.13 & 2.92 & 3.13 & 3.13 & 2.92 & 2.92 \\
\hline & 54.54 & .10 & .13 & .10 & .10 & .13 & .13 \\
\hline & 54.46 & 1.00 & 1.01 & 1.00 & 1.00 & 1.01 & 1.01 \\
\hline & 54.12 & 1.81 & 1.85 & 1.81 & 1.81 & 1.85 & 1.85 \\
\hline & 53.73 & 2.20 & 2.19 & 2.20 & 2.20 & 2.19 & 2.19 \\
\hline & 53.19 & 2.54 & 2.51 & 2.54 & 2.54 & 2.51 & 2.51 \\
\hline \multirow{5}{*}{ 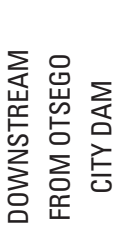 } & 52.59 & 2.13 & 2.12 & 2.13 & 2.13 & 2.12 & 2.12 \\
\hline & 52.25 & .97 & .97 & .97 & .97 & .97 & .97 \\
\hline & 51.83 & 1.42 & 1.42 & 1.42 & 1.42 & 1.42 & 1.42 \\
\hline & 51.43 & 1.65 & 1.64 & 1.65 & 1.65 & 1.64 & 1.64 \\
\hline & 51.23 & 0.77 & 0.84 & 0.77 & 0.77 & 0.84 & 0.84 \\
\hline
\end{tabular}

'Flood conditions refers

20 will erode away and the bank toe will resemble that shown in figure 22 .

Locations that are the most prone to toe erosion under present conditions were found at the upper ends of the impoundments or just below a dam (cross-sections 56.67, 54.68-R, 54.68-L, 54.61-R, 54.61-L, 52.59, and 52.25) as well as near bridges where the river was moving into a bend (cross sections 56.03 and 51.23). The relation between the locations of modeled erosion and their placement along the river emphasizes the importance of the geomorphic processes that are at work. The upper ends of the impoundments have steeper slopes than within the impoundments themselves (fig. 17). These steeper slopes result in higher velocities and increased shear stresses that are acting on the bank and removing toe material. Accelerated removal of the toe material reduces the stability of the bank. At bridges in the study reach, the river becomes constricted as it passes, which also increases the instream velocities, thereby removing toe material. Occur- rences of bends in the river accentuate the erosion process by forcing water into the bank, which removes additional bank sediments.

Under flood conditions, the same pattern of increased toe erosion and decreased bank stability at locations of increased velocity and the presence of bridges and bends was observed. Assessment results show that the banks of the Kalamazoo River are primarily stable and have bank toes that are subject to erosion. Locations prone to bank toe erosion are found to be related to the occurrence of human-made features, such as bridges, and the occurrence or potential for channel slopes within the reach to become steepened. The erosion of instream sediments within the present impoundments would result in an increase in channel slope (Syed and Bennett, 2004). The slopes used in this analysis are listed by reach in table 1. Locations that did not reflect an appreciable change in slope between the present and flood conditions are a function of the length time modeled. Under flood conditions, headward 


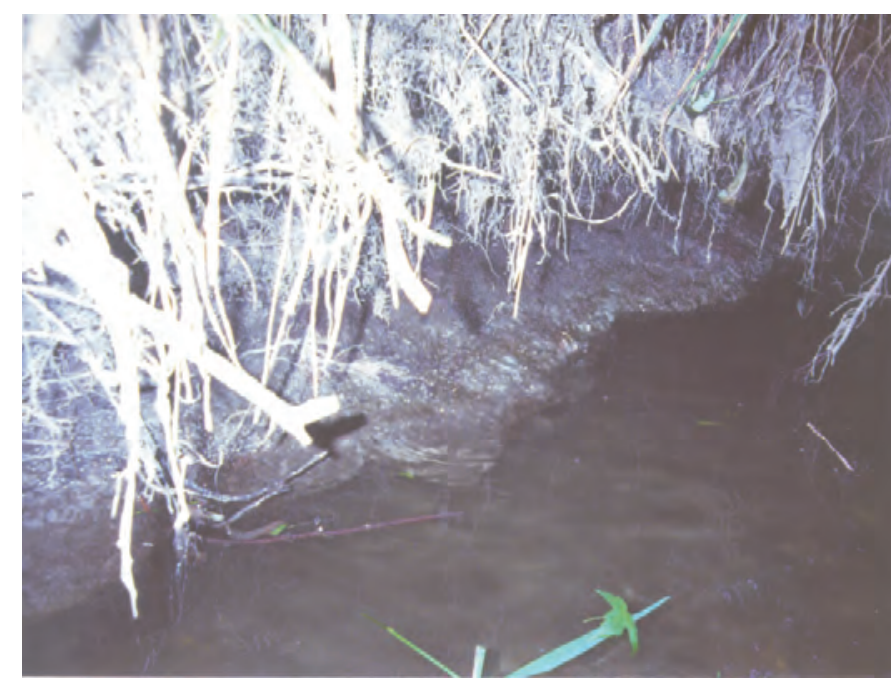

Figure 20. Undercut banks typical of the Plainwell to Otsego reach, Kalamazoo River, Michigan. Photograph by C.M. Rachol.

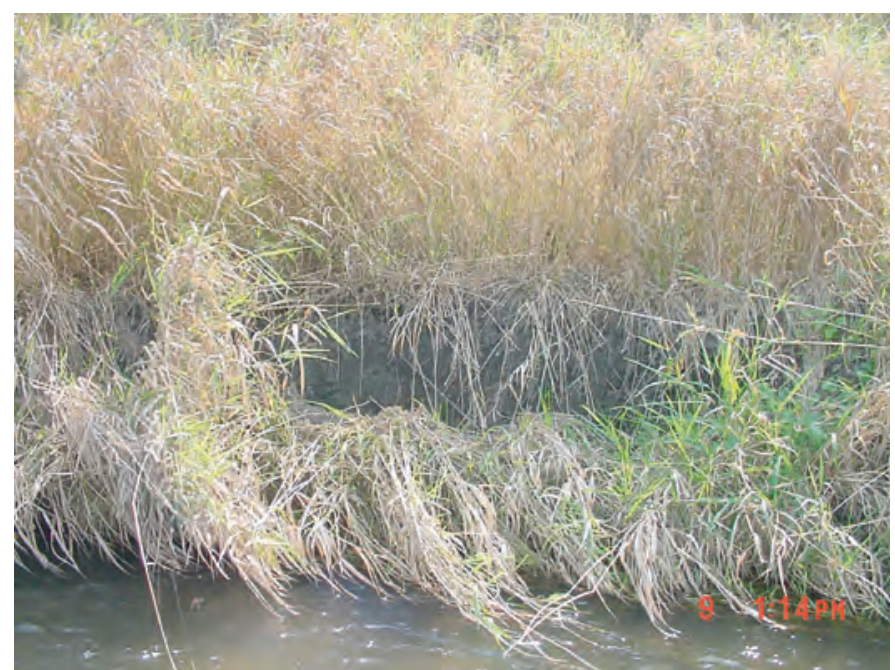

Figure 21. Localized bank failure site included in sstudy (river mile 51.23; see Figure 11), Kalamazoo River, Michigan. (Failed bank is approximately 6 feet wide) Photograph by C.M. Rachol.

erosion of the bed increases the streambank height. Over time, the stability of the streambanks would become decreased.

\section{SUMMARY AND CONCLUSIONS}

Dams, diversion structures, and channelization have affected the Kalamazoo River since the mid-1800s. Modification of the river has led to the development of a variety of depositional environments that would otherwise not have been present; some of these environments contain polychlorinated biphenyls (PCBs) from papermill carbonless copy paper production. The Michigan Department of Environmental Qual-

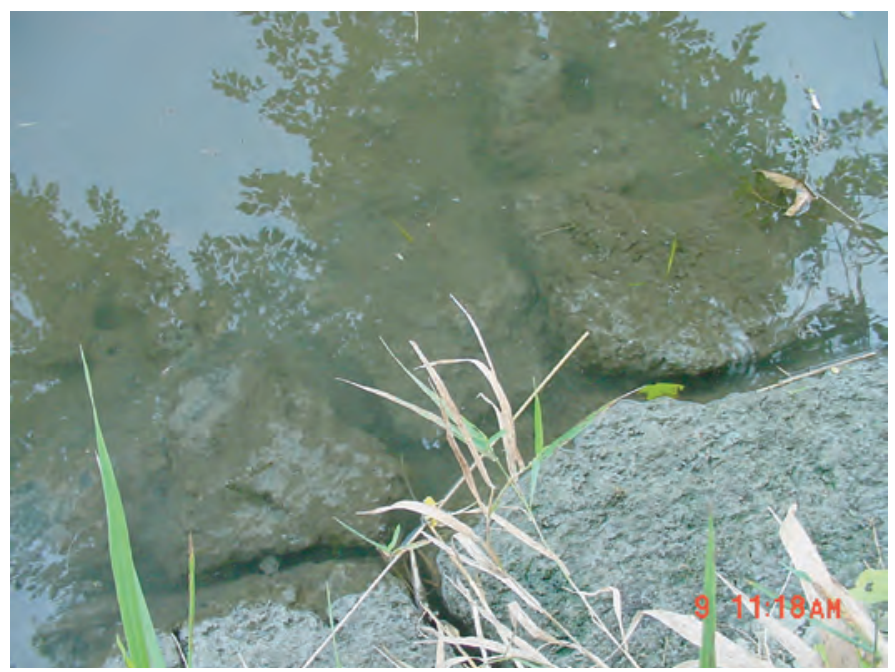

Figure 22. Material eroded from the bank becomes part of the bank toe, Kalamazoo River, Michigan. Photograph by C.M. Rachol.

ity (MDEQ) and the U.S. Environmental Protection Agency (USEPA) are interested in quantifying the present geomorphic condition of the river channel, its flood plain, wetlands, and previous depositional surfaces. The MDEQ and USEPA would like to identify areas of high bank-erosion potential and reaches prone to channel avulsion. Therefore, the U.S. Geological Survey (USGS), in cooperation with the MDEQ and USEPA, began a study concerning historical and simulated changes in channel characteristics from Plainwell to Otsego on the Kalamazoo River, Michigan. The findings of the study reported herein include hydraulic geometry and slope data for use in future simulations in erosion and sediment transport, descriptions of historical changes in planform and slope, and assessments of bank stability under present hydrologic conditions and flood conditions.

- Comparison of aerial photography from 1938, 1981, and 1999 with early to mid-1800s General Land Office Survey notes show that the Kalamazoo River channel has stayed within the confines of its glacial valley for the period of record. Major changes in the channel form were the result of either natural processes (resulting in the formation and evolution of meander bends) or the building of dams and adjustment of impounded water levels (resulting in the mobilization of sediments).

- The USGS in 2002 collected detailed bank-profile data along the Kalamazoo River between the cities of Plainwell and Otsego, Mich. These data were combined with USGS 2001 data for channel and bottom elevations and valley cross-section data collected by a consulting firm and supplemented with data from USGS 7.5-minute topographic quadrangle maps. The resulting cross sections were used as part of this study for the bank-stability analysis and by the U.S. Depart- 
ment of Agriculture-Agricultural Research Service for simulating sediment movement through the detailed reach.

- The stability of streambanks along a 5-mi reach of the Kalamazoo River from the city of Plainwell to below the Otsego City Dam was studied. The results of the bank-stability assessments showed that the bank toes were prone to erosion, resulting in the formation of an under cut bank profile. Under present conditions, unstable banks were found close to meander bends and bridges, and steeper channel slopes. Compared to the rest of the channel, these locations had higher streamflow velocities and shear stress, which resulted in larger amounts of undercutting and instability. Under a flood scenario, locations that were unstable under present conditions remained unstable, and the slopes within the impoundments became steepened as in stream sediments were eroded.

\section{Acknowledgments}

The authors thank Todd King (Camp, Dresser, and McKee, Inc., Detroit, Mich.) and Paul Bucholtz (Michigan Department of Environmental Quality, Lansing, Mich.) for their technical support. Krista Stensvold (U.S. Geological Survey, Middleton, Wis.) and Josef Schuler (U.S. Geological Survey, Rice Lake, Wis.) performed bank-profile surveys. Michelle Lutz (U.S. Geological Survey, Middleton, Wis.) provided cross-section database support. Marie Peppler, U.S. Geological Survey, Middleton, Wis.) provided graphical support. Bernard Lenz (U.S. Geological Survey, Rice Lake, Wis.) conducted HEC-RAS analysis of the designed channel. Personnel at the Remote Sensing and Geographic Information Sciences Research and Outreach Services at Michigan State University assisted in the digital processing of historical aerial photographs. Personnel from Camp, Dresser, and McKee Inc., provided the 1999 aerial photographs. Sharon Baltusis (U.S. Geological Survey, Lansing, Mich.) furnished editorial and graphic support. Kyle Juracek (U.S. Geological Survey, Lawrence, Kans.) and Tim Straub (U.S. Geological Survey, Urbana, Ill.) served as technical reviewers.

\section{REFERENCES CITED}

Amiri-Tokaldany, Ebrahim, Darby, S.E., and Tosswell, P., 2003, Bank stability analysis for predicting reach scale land loss and sediment yield: Journal of the American Water Resources Association, v. 39, no. 4, p. 897-909.
Anderson, J.D., 1991, Predicted fluvial response to dam removal in the Kalamazoo River Valley, Michigan in Hydraulic Engineering: Proceedings of the 1991 National Conference, Nashville, Tenn., American Society of Civil Engineers, p. 686-691.

Budhu, Muni, 2000, Soil mechanics and foundations: New York, John Wiley and Sons, p. 524-528.

Blasland, Bouck, and Lee, Inc., 1994, Allied Paper, Inc./Portage Creek/Kalamazoo River Superfund site remedial investigation/feasibility study: Draft technical memorandum 10-Sediment characterization/geostatistical pilot study.

Blasland, Bouck, and Lee, Inc., 1996, Allied Paper, Inc./Portage Creek/Kalamazoo River Superfund site remedial investigation/feasibility study: Technical memorandum 15-Mill Investigation, v. 1.

Blumer, S.P., Behrendt, T.E., Ellis, J.M., Minnerick, R.J., LeuVoy, R.L., and Whited, C.R., 2003, Water resources data, Michigan, water year 2002: U.S. Geological Survey Water-Data Report MI-02-1, 113 p.

Brunner, G.W., 2002, HEC-RAS River Analysis System user's manual: U.S. Army Corps of Engineers, 420 p.

Comer, P.J., Albert, D.A., and Austin, M.B., 1998, Digital map of vegetation of Michigan circa 1800-An interpretation of the General Land Office Surveys: Data from Michigan Natural Features Inventory Report 1995-07 available by county on the Web, accessed on June 26, 2003, at http://www.mcgi.state.mi.us/mgdl/ ?rel=thext\&action $=$ thmname $\&$ cid $=5 \&$ cat $=$ Land + Cover + Circa +1800

Dalrymple, D., 1972, Bah Jove! Otsego is the Dandy Town: Otsego, Mich., self-published, 13 p.

Dalrymple, D., 1983, Memories of Pine Creek: Otsego, Mich., self-published, $27 \mathrm{p}$.

Deutsch, M., Vanlier, K.E., and Giroux, P.R., 1960, Ground water hydrology and glacial geology of the Kalamazoo area, Michigan: U.S. Geological Survey, 122 p.

Dorr, J.A., and Eschman, D.F., 1970, Geology of Michigan: Ann Arbor, Mich., University of Michigan Press, p. $158-163$.

Easson, G., and Yarbrough, L.D., 2002, The effects of riparian vegetation on bank stability: Environmental Geoscience, v. 8 , no. 4 , p. $247-269$.

ERDAS, 2001, IMAGINE OrthoBase user's guide: Atlanta, Ga., ERDAS, Inc., 524 p.

Federal Geographic Data Committee, 1998, Geospatial 
positioning accuracy standards, Part 3-National standard for spatial data accuracy: FGDC publication FGDCSTD-007.3-1998, 28 p.

Fitzpatrick, F.A, Knox, J.C., and Whitman, H.E., 1999, Effects of historical land-cover changes on flooding and sedimentation, North Fish Creek, Wisconsin: U.S. Geological Survey Water-Resources Investigations Report 99-4083, 12 p.

Fredlund, D.G., Morgenstern, N.R., and Widger, R.A., 1978, The shear strength of unsaturated soils: Canadian Geotechnical Journal, v. 15, p. 313-321.

Gephart, G.D., and Larson, G.J., 1982, Surficial geology of Allegan County, Michigan: East Lansing, Mich., Michigan State University, Department of Geology, 1:100,000-scale map.

Handy, R.L., and Fox N.S., 1967, A soil bore-hole direct-shear test device: Highway Research Board News, v. 27, p. $42-51$.

Hanson, G.J., and Simon A., 2001, Erodibility of cohesive streambeds in the loess area of the Midwestern USA: Hydrological Processes, v. 15, no. 1, p. 23-38.

Howe, R., 1960, The application of aerial photographic interpretation to the investigation of hydrologic problems: Photogrammetric Engineering, v. 26, no. 1, p. 85-95.

Huggler, T., 1996, Fish Michigan-50 more rivers: Davison, Mich., Friede Publications, 103 p.

Knapp, B.D., 1987, Soil Survey of Allegan County, Michigan, for Michigan: Washington, D.C., U.S. Department of Agriculture, Soil Conservation Service, p. 2.

Minami, M., 2001, Using ArcMap: Redlands, Calif., ESRI Press, 544 p.

Monaghan, G.W., and Larson, G.J., 1984, Glacial geology of Kalamazoo County, Michigan: East Lansing, Mich., Michigan State University, Department of Geology, 35 p.

Nevins, A., and Dalrymple, D., 1975, As it was in Otsego: Otsego, Mich., Otsego Bicentennial Committee, 64 p.

Osman, A.M., and Thorne, C.R., 1988, Riverbank stability analysis, part I: Journal of Hydraulic Engineering, v. 114, p. 134-149.

Rheaume, S.J., Rachol, C.M., Hubbell, D.L., and Simard, A., 2002, Sediment characteristics and configuration within three dam impoundments on the Kalamazoo River, Michigan, 2000: U.S. Geological Survey Water-
Resources Investigations Report 02-4098, 51 p.

Rheaume, S.J., Hubbell, D.L., Rachol, C.M., Simard A., and Fuller L.M., 2003, Sediment characteristics and configuration within the Otsego City Dam impoundment on the Kalamazoo River, Michigan, 2001-02: U.S. Geological Survey Water-Resources Investigations Report 03-4218, 54 p.

Riggs, C.H., 1938, Geology of Allegan County: Lansing, Mich., Michigan Department of Conservation, Geological Survey Division, p. 2-7.

Roy F. Weston, Inc., 2002, Removal assessment report for Allied Paper-Kalamazoo River site, Otsego/Plainwell, Michigan: TDD No. 0103-002, Document Control No. 67-2A-ABAB, sec. 2-5.

Schumm, S.A., 1977, The fluvial system: New York, John Wiley and Sons, 338 p.

Simard, A., 2003, Annotated bibliography of selected references on PCB and the Kalamazoo River Superfund Site, Michigan, 1982-2002: U.S. Geological Survey Open-File Report 03-338, 24 p.

Simon, A., and Collison, A.J., 2002, Quantifying the mechanical and hydrologic effects of riparian vegetation on streambank stability: Earth Surface Processes and Landforms, v. 27, p. 527-546.

Simon, A., Curini, A., Darby, S.E., and Langendoen, E.J., 2000, Bank and near-bank processes in an incised channel: Geomorphology, v. 35, p. 193-217.

Simon, A., Langendoen, E.J., Thomas, R.E., and Layzell, A., 2003, ARS Bank-Stability and Toe-Erosion Model, accessed February 2003 at, http://www.sedlab.olemiss. edu/cwp_unit/bank.htmp.

Syed, A.U., and Bennett, J.P., 2004, A pre-dam removal assessment of sediment transport for four dams on the Kalamazoo River between the cities of Plainwell and Allegan, Michigan: U.S. Geological Survey Scientific Investigations Report 2004-5178, 79 p.

Thorne, C.R., Murphey, J.B., and Little, W.C., 1981, Stream channel stability, Appendix D-Bank stability and bank material properties in the bluffline streams of northwest Mississippi: Oxford, Miss., U.S. Department of Agriculture, Agricultural Research Service, National Sedimentation Laboratory, p. 188-201.

U.S. Department of Agriculture Soil Conservation Service, 1994, State Soil Geographic (STATSGO) Data Base: Fort Worth, Tex., 113 p. 
U.S. Navy, 1986, Slope stability and protection, in Soil mechanics design manual 7.01: Naval Facilities Engineering Command, p. 309-334.

Vogelmann, J.E., Howard, S.M., Yang, L., Larson, C.R., Wylie, B.K., and Van Driel, N., 2001, Completion of the 1990s National Land Cover Data Set for the conterminous United States from Landsat Thematic Mapper data and ancillary data sources: Photogrammetric Engineering and Remote Sensing, v. 67, p. 650-652.

Wells, R.R., Langendoen, E.J., and Simon, A., 2003, Numerical simulation of sediment loads and channel changes along the Kalamazoo River between Plainwell and Otsego, Michigan: Oxford, Miss., U.S. Department of Agriculture, Agricultural Research Service, National Sedimentation Laboratory, $45 \mathrm{p}$.

W.F. Baird and Associates, 1999, Saugatuck Harbor Impact Assessment: Report for the Detroit District U.S. Army Corps of Engineers, Madison, Wisconsin, 75 p. 
Appendix A. Valley and designed cross sections for the Kalamazoo River from Plainwell to Otsego, Michigan 
Appendix A. Valley and designed cross sections for the Kalamazoo River from Plainwell to Otsego, Michigan. Designed channel modifications shown by dashed line; cross-section extensions based on topographic map elevations shown in grey. Cross-section locations within study reach are shown on Figure 14.
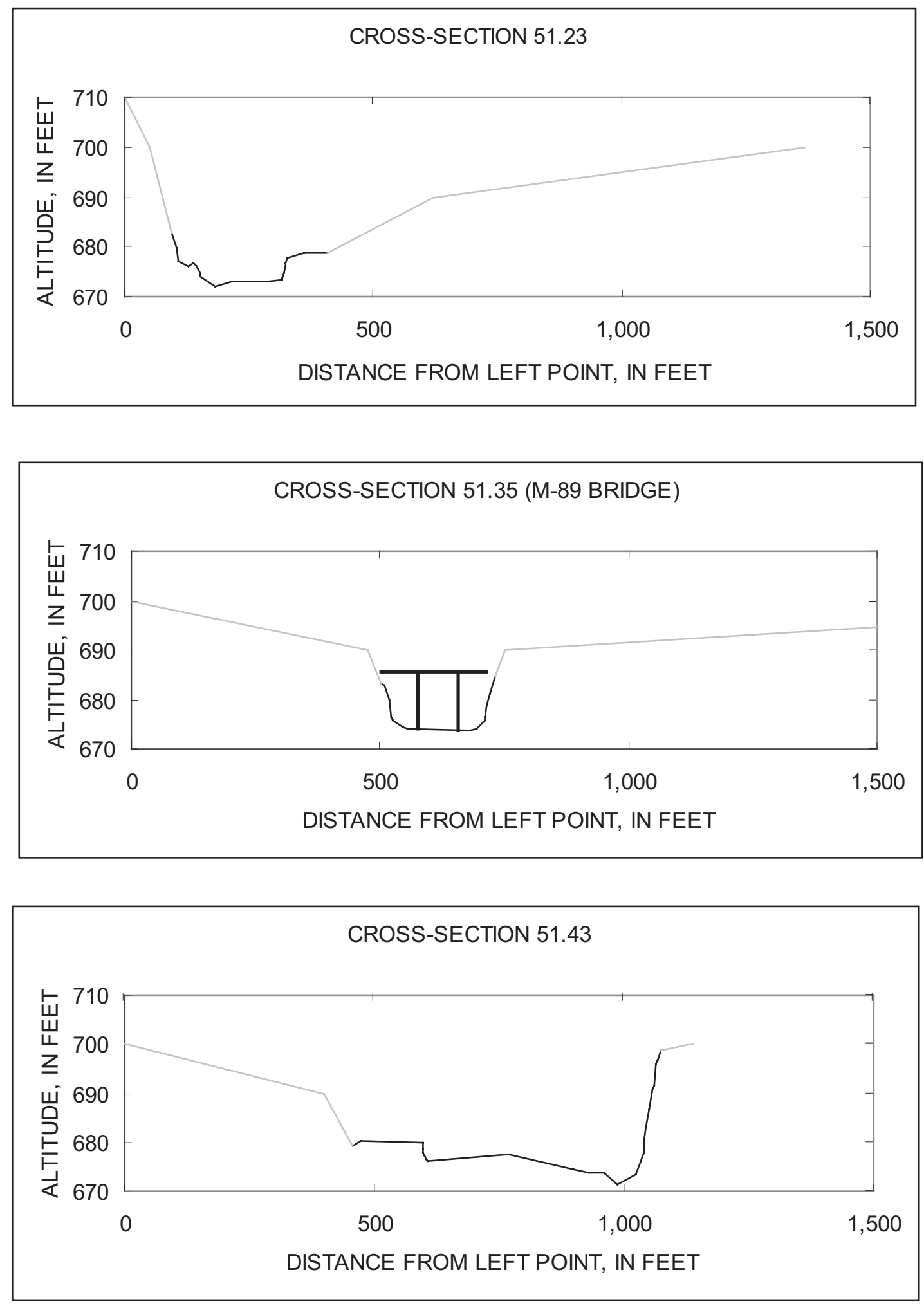
Appendix A. Valley and designed cross sections for the Kalamazoo River from Plainwell to Otsego, Michigan. Designed channel modifications shown by dashed line; cross-section extensions based on topographic map elevations shown in grey. Cross-section locations within study reach are shown on Figure 14 -- continued.
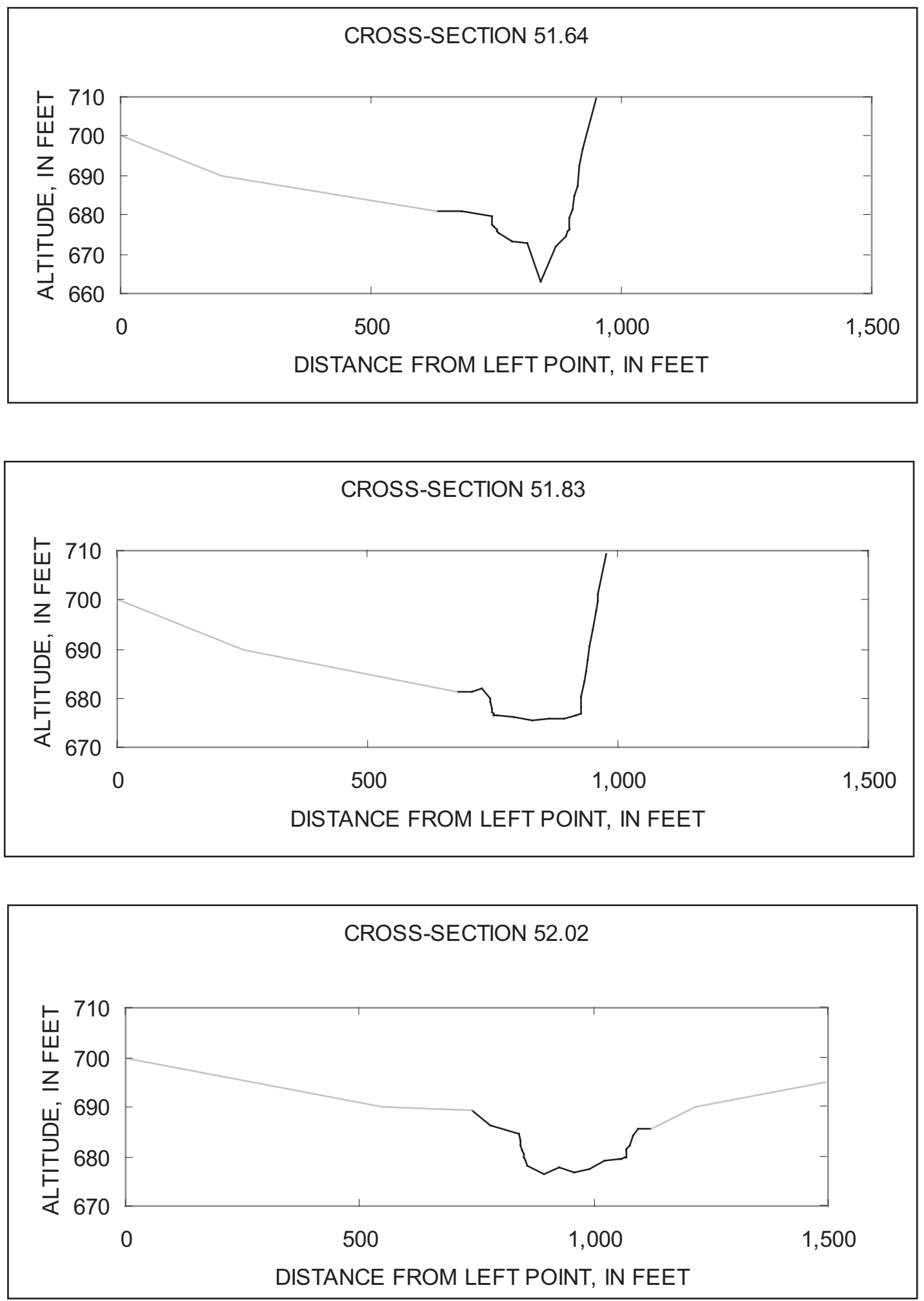
Appendix A. Valley and designed cross sections for the Kalamazoo River from Plainwell to Otsego, Michigan. Designed channel modifications shown by dashed line; cross-section extensions based on topographic map elevations shown in grey. Cross-section locations within study reach are shown on Figure 14 -- continued.
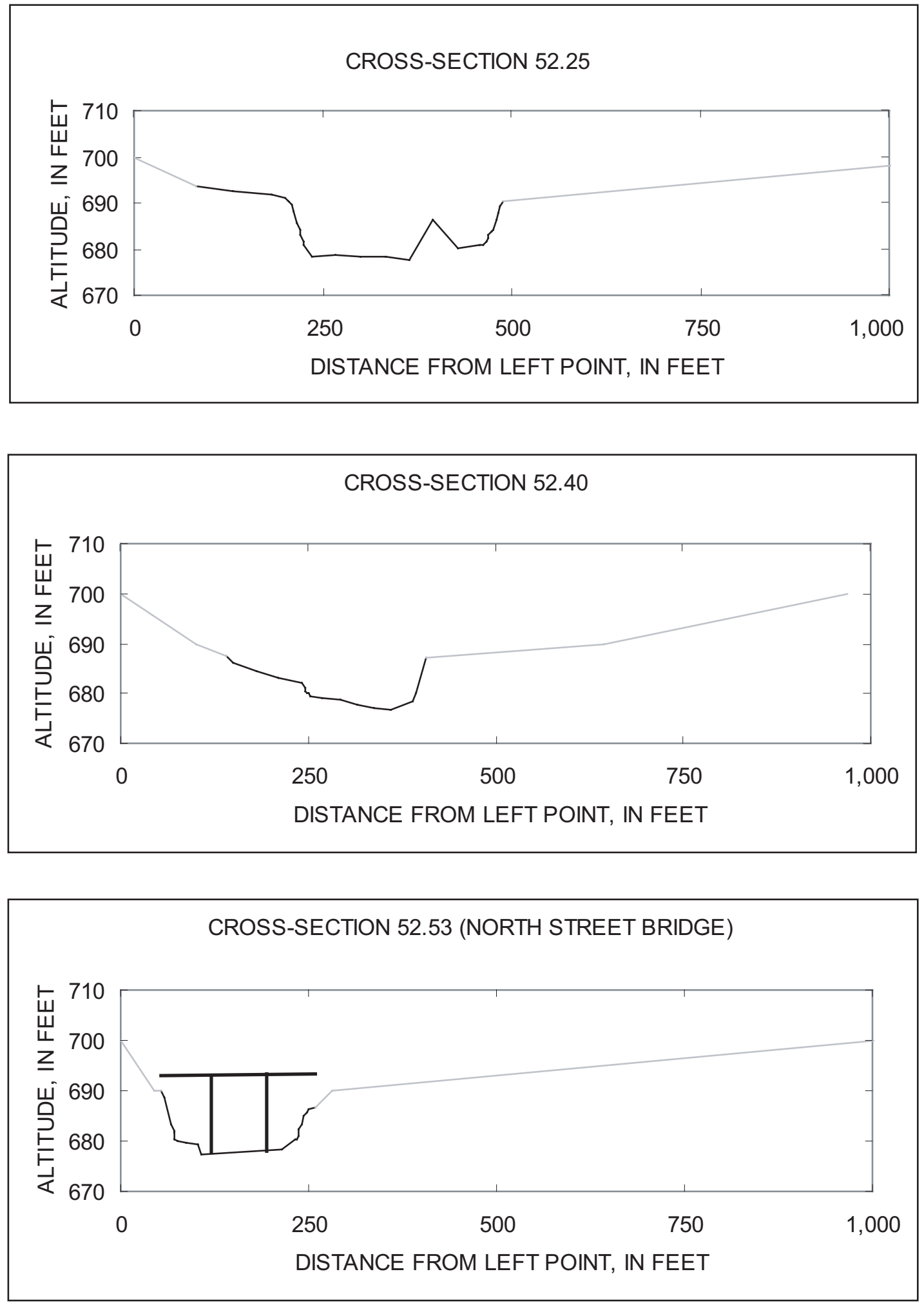
Appendix A. Valley and designed cross sections for the Kalamazoo River from Plainwell to Otsego, Michigan. Designed channel modifications shown by dashed line; cross-section extensions based on topographic map elevations shown in grey. Cross-section locations within study reach are shown on Figure 14 -- continued.
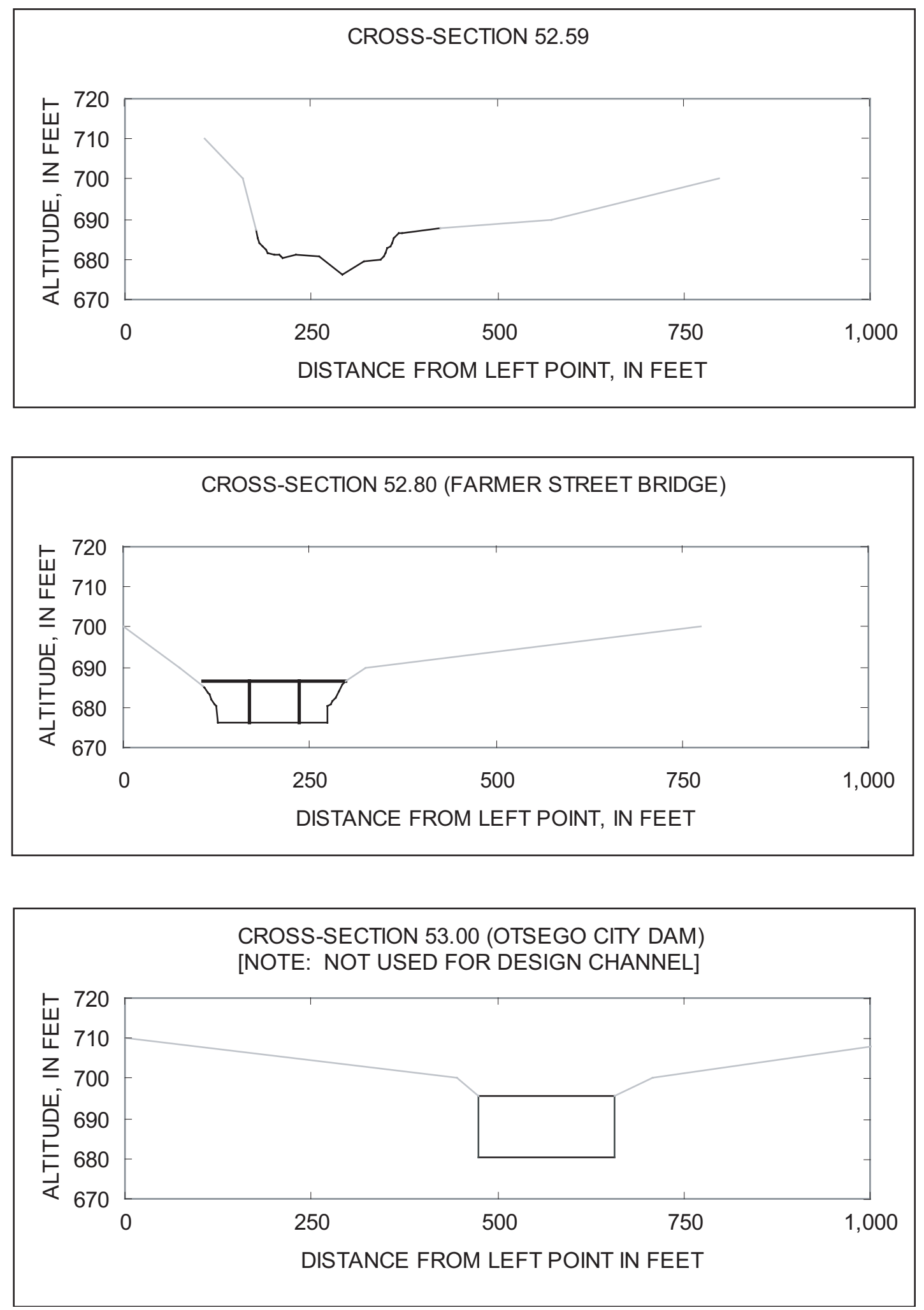
Appendix A. Valley and designed cross sections for the Kalamazoo River from Plainwell to Otsego, Michigan. Designed channel modifications shown by dashed line; cross-section extensions based on topographic map elevations shown in grey. Cross-section locations within study reach are shown on Figure 14 -- continued.
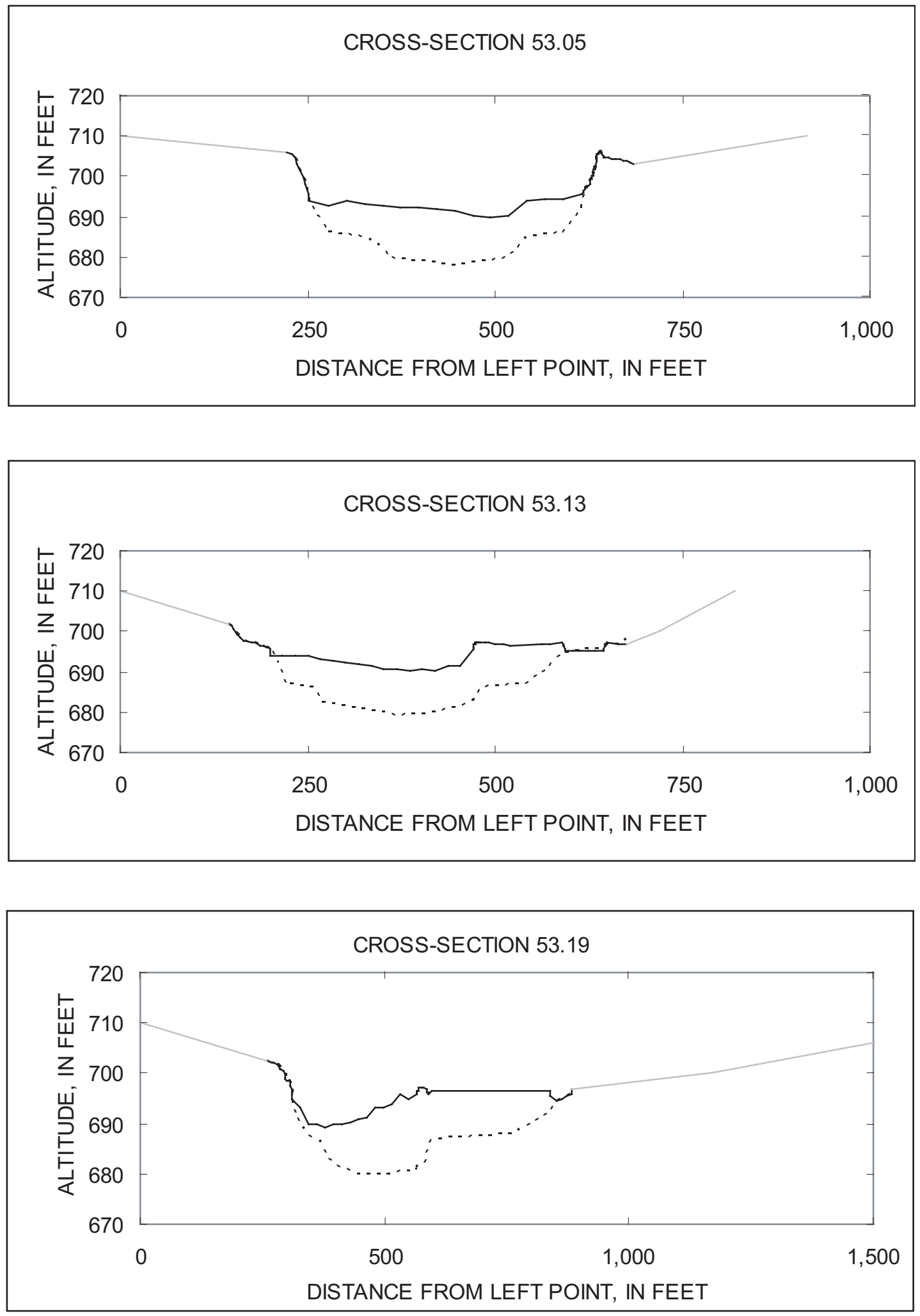
Appendix A. Valley and designed cross sections for the Kalamazoo River from Plainwell to Otsego, Michigan. Designed channel modifications shown by dashed line; cross-section extensions based on topographic map elevations shown in grey. Cross-section locations within study reach are shown on Figure 14 -- continued.
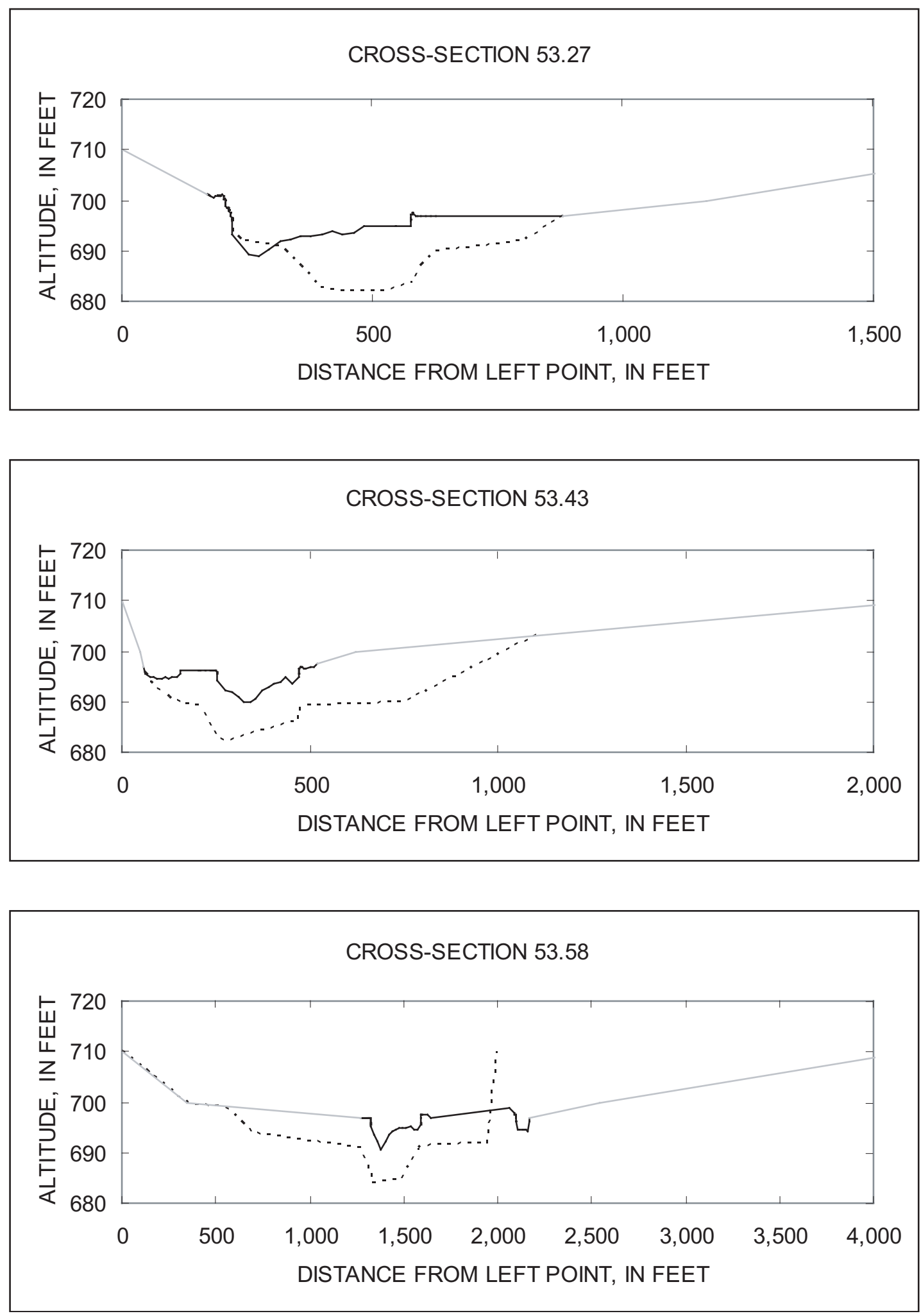
Appendix A. Valley and designed cross sections for the Kalamazoo River from Plainwell to Otsego, Michigan. Designed channel modifications shown by dashed line; cross-section extensions based on topographic map elevations shown in grey. Cross-section locations within study reach are shown on Figure 14 -- continued.

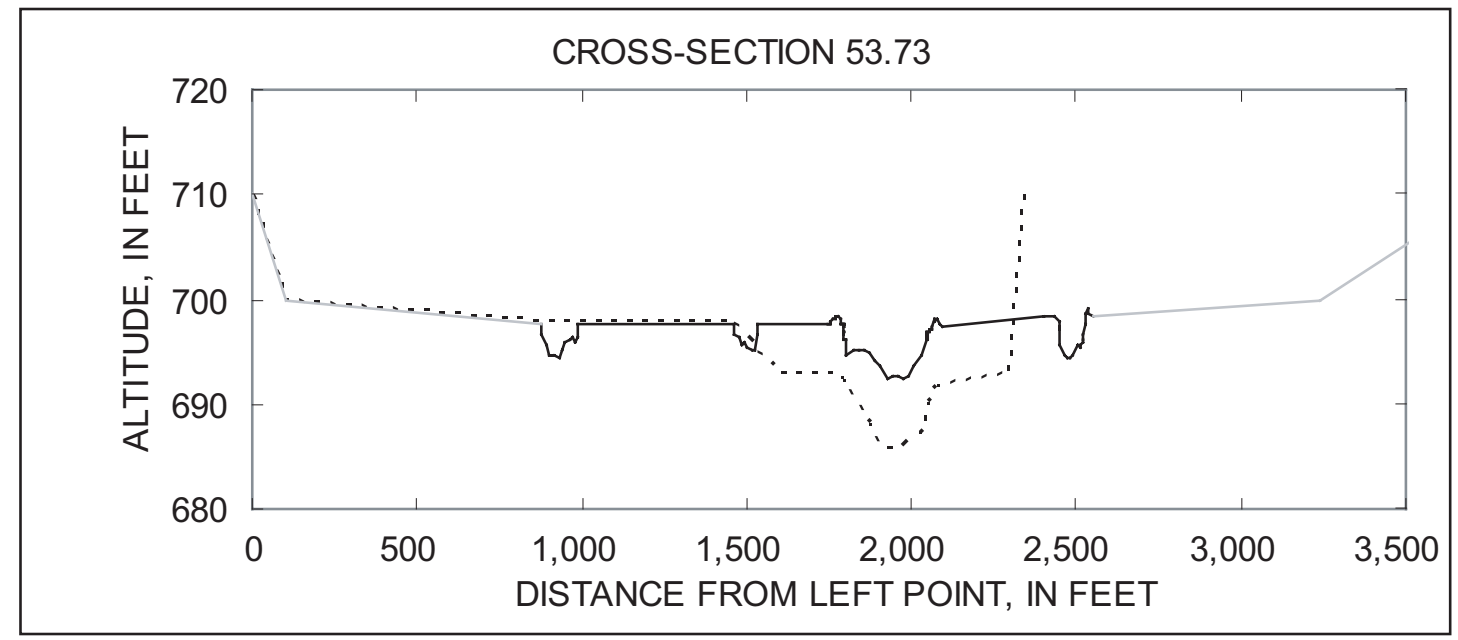

CROSS-SECTION 53.89

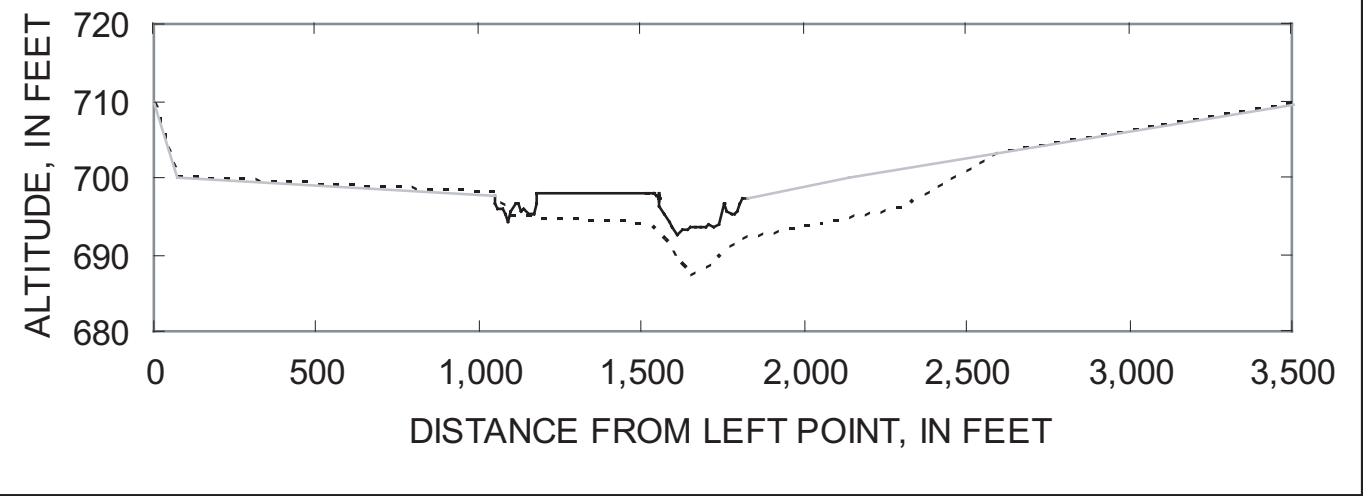

CROSS-SECTION 54.02

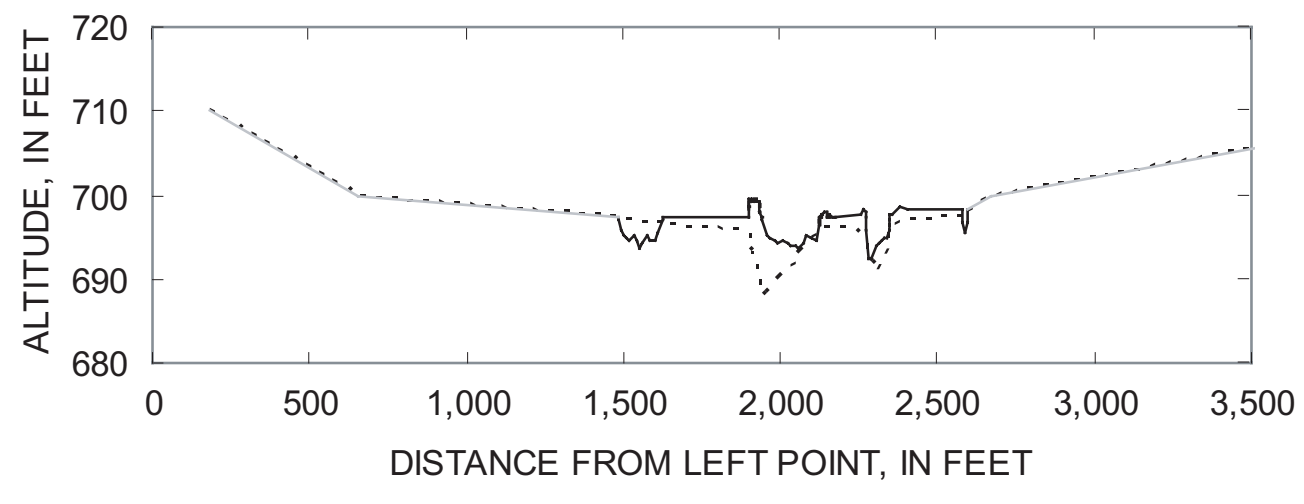


Appendix A. Valley and designed cross sections for the Kalamazoo River from Plainwell to Otsego, Michigan. Designed channel modifications shown by dashed line; cross-section extensions based on topographic map elevations shown in grey. Cross-section locations within study reach are shown on Figure 14 -- continued.
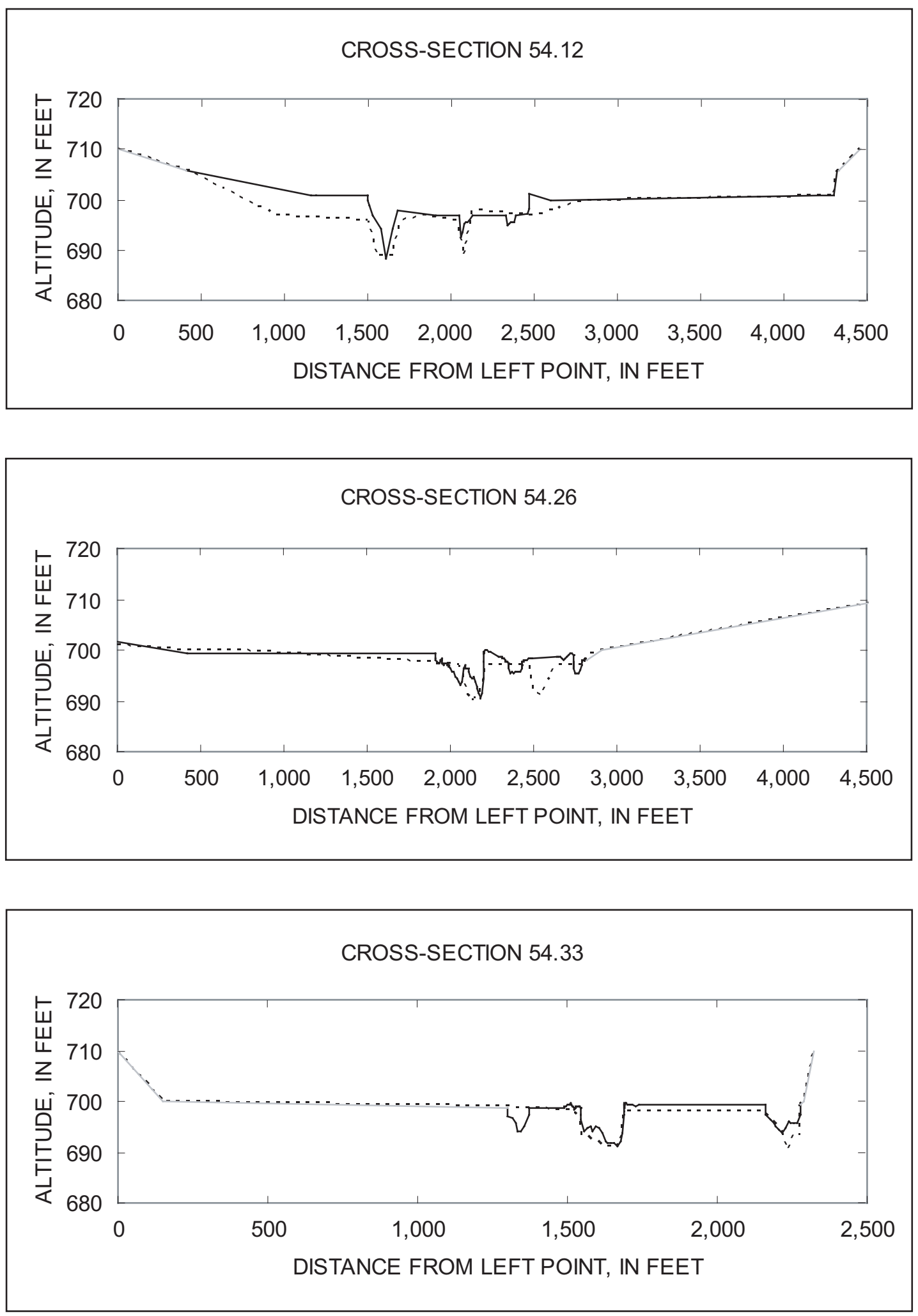
Appendix A. Valley and designed cross sections for the Kalamazoo River from Plainwell to Otsego, Michigan. Designed channel modifications shown by dashed line; cross-section extensions based on topographic map elevations shown in grey. Cross-section locations within study reach are shown on Figure 14 -- continued.
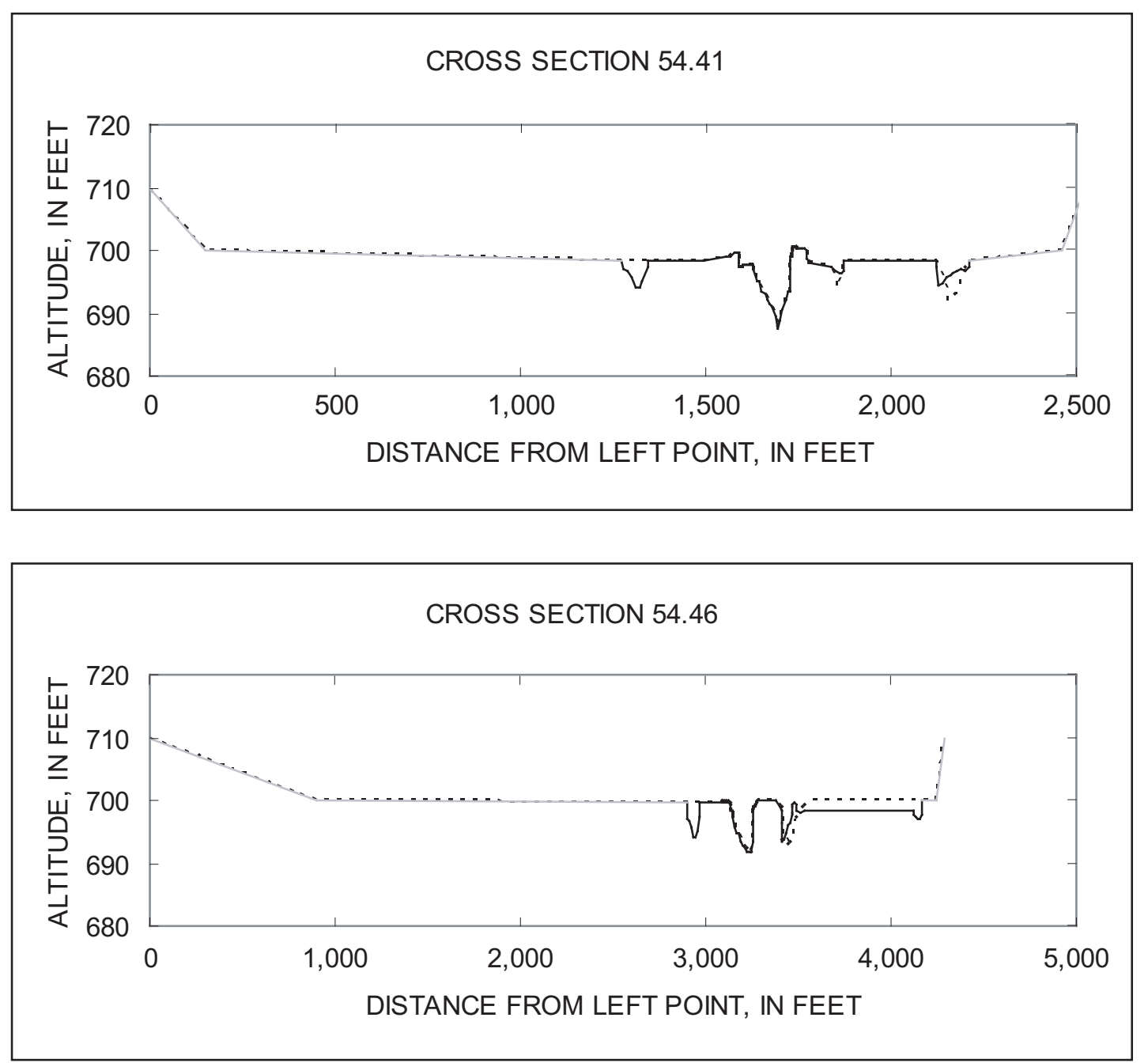

CROSS-SECTION 54.54

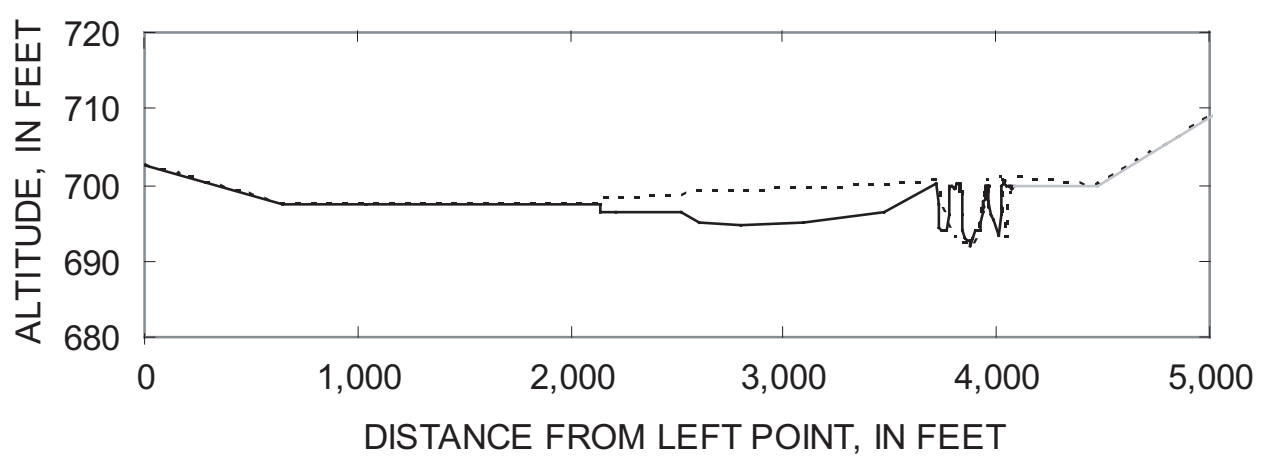


Appendix A. Valley and designed cross sections for the Kalamazoo River from Plainwell to Otsego, Michigan. Designed channel modifications shown by dashed line; cross-section extensions based on topographic map elevations shown in grey. Cross-section locations within study reach are shown on Figure 14 -- continued.
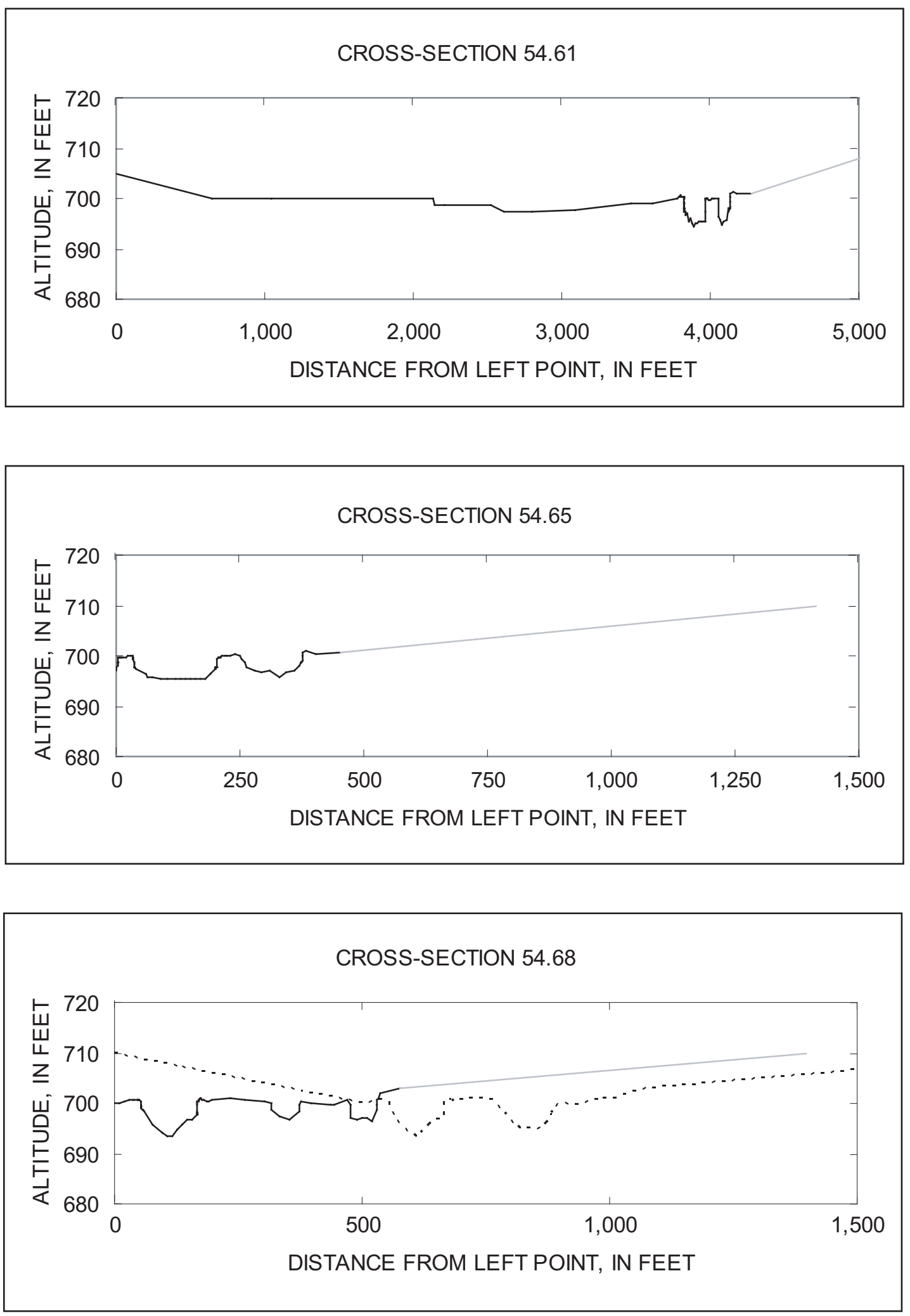
Appendix A. Valley and designed cross sections for the Kalamazoo River from Plainwell to Otsego, Michigan. Designed channel modifications shown by dashed line; cross-section extensions based on topographic map elevations shown in grey. Cross-section locations within study reach are shown on Figure 14 -- continued.
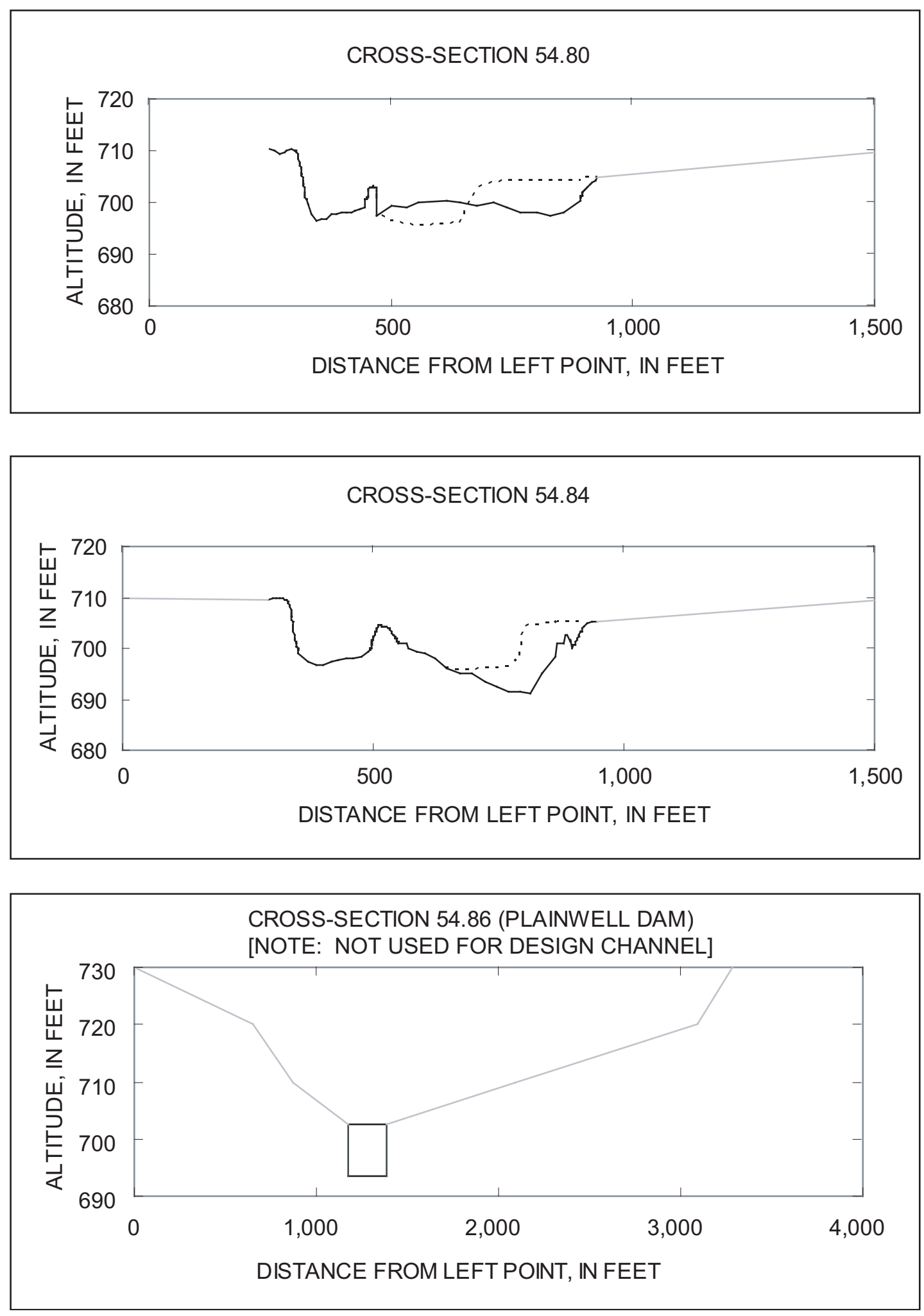
Appendix A. Valley and designed cross sections for the Kalamazoo River from Plainwell to Otsego, Michigan. Designed channel modifications shown by dashed line; cross-section extensions based on topographic map elevations shown in grey. Cross-section locations within study reach are shown on Figure 14 -- continued.
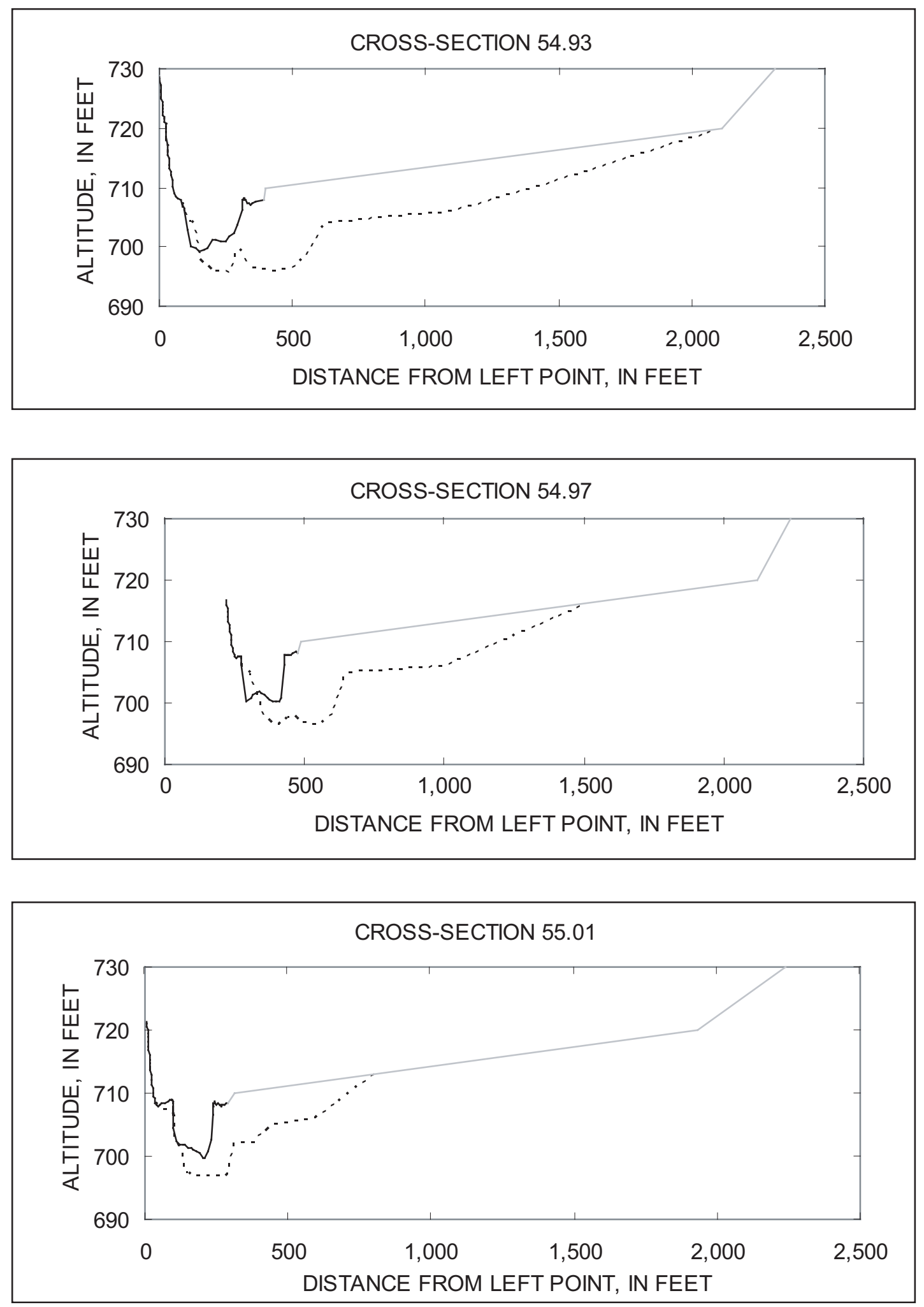
Appendix A. Valley and designed cross sections for the Kalamazoo River from Plainwell to Otsego, Michigan. Designed channel modifications shown by dashed line; cross-section extensions based on topographic map elevations shown in grey. Cross-section locations within study reach are shown on Figure 14 -- continued.
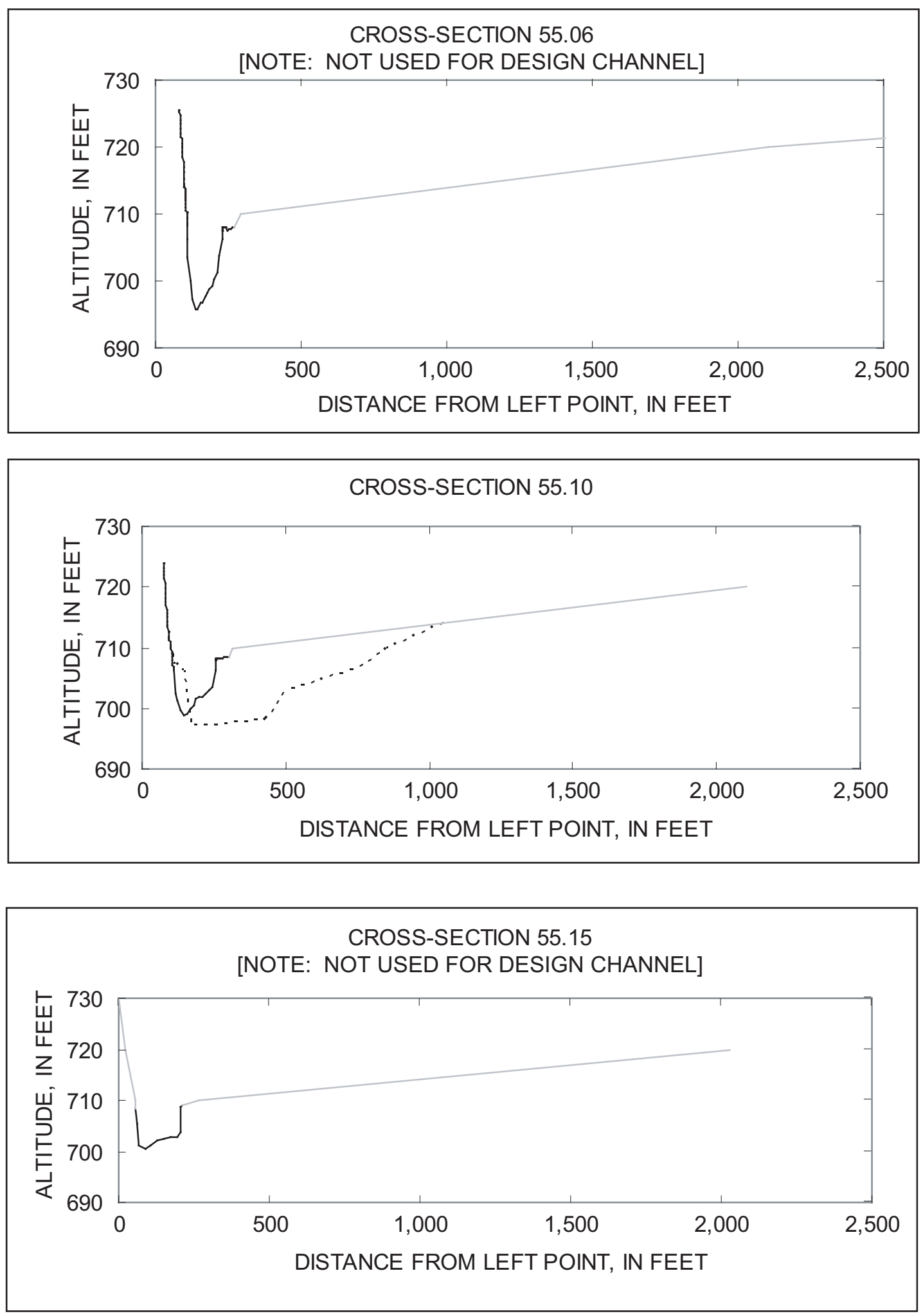
Appendix A. Valley and designed cross sections for the Kalamazoo River from Plainwell to Otsego, Michigan. Designed channel modifications shown by dashed line; cross-section extensions based on topographic map elevations shown in grey. Cross-section locations within study reach are shown on Figure 14 -- continued.
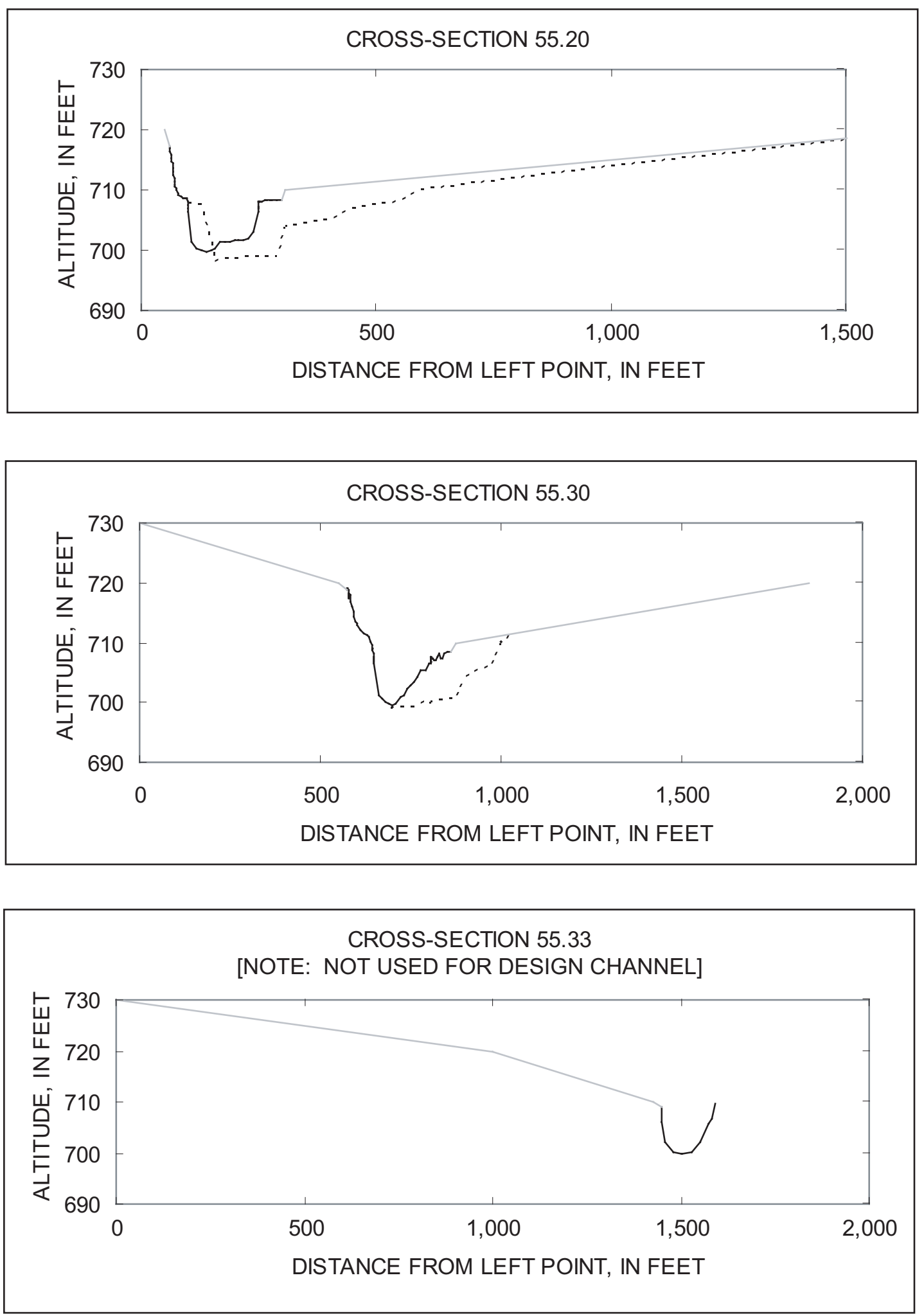
Appendix A. Valley and designed cross sections for the Kalamazoo River from Plainwell to Otsego, Michigan. Designed channel modifications shown by dashed line; cross-section extensions based on topographic map elevations shown in grey. Cross-section locations within study reach are shown on Figure 14 -- continued.
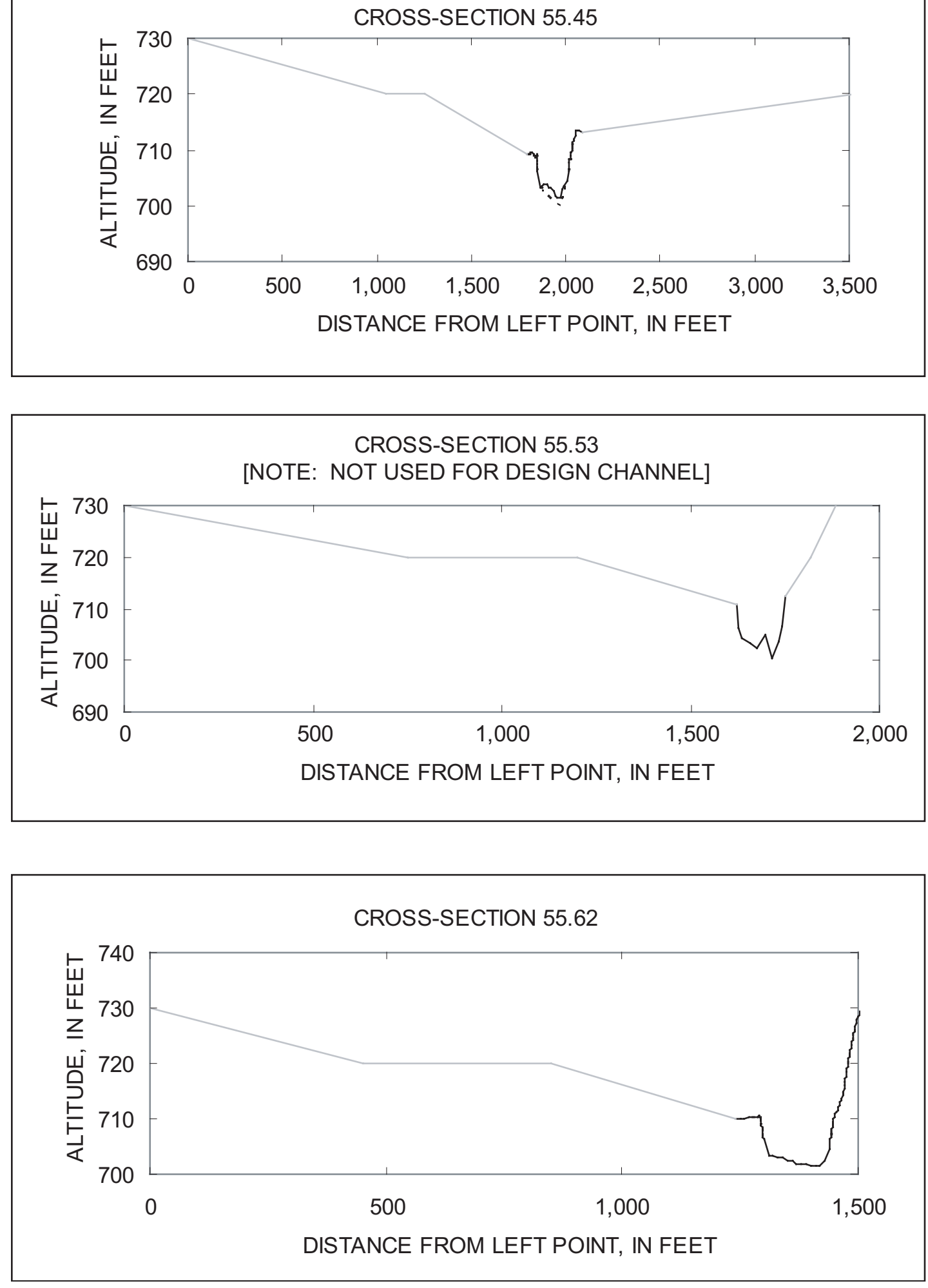
Appendix A. Valley and designed cross sections for the Kalamazoo River from Plainwell to Otsego, Michigan. Designed channel modifications shown by dashed line; cross-section extensions based on topographic map elevations shown in grey. Cross-section locations within study reach are shown on Figure 14 -- continued.
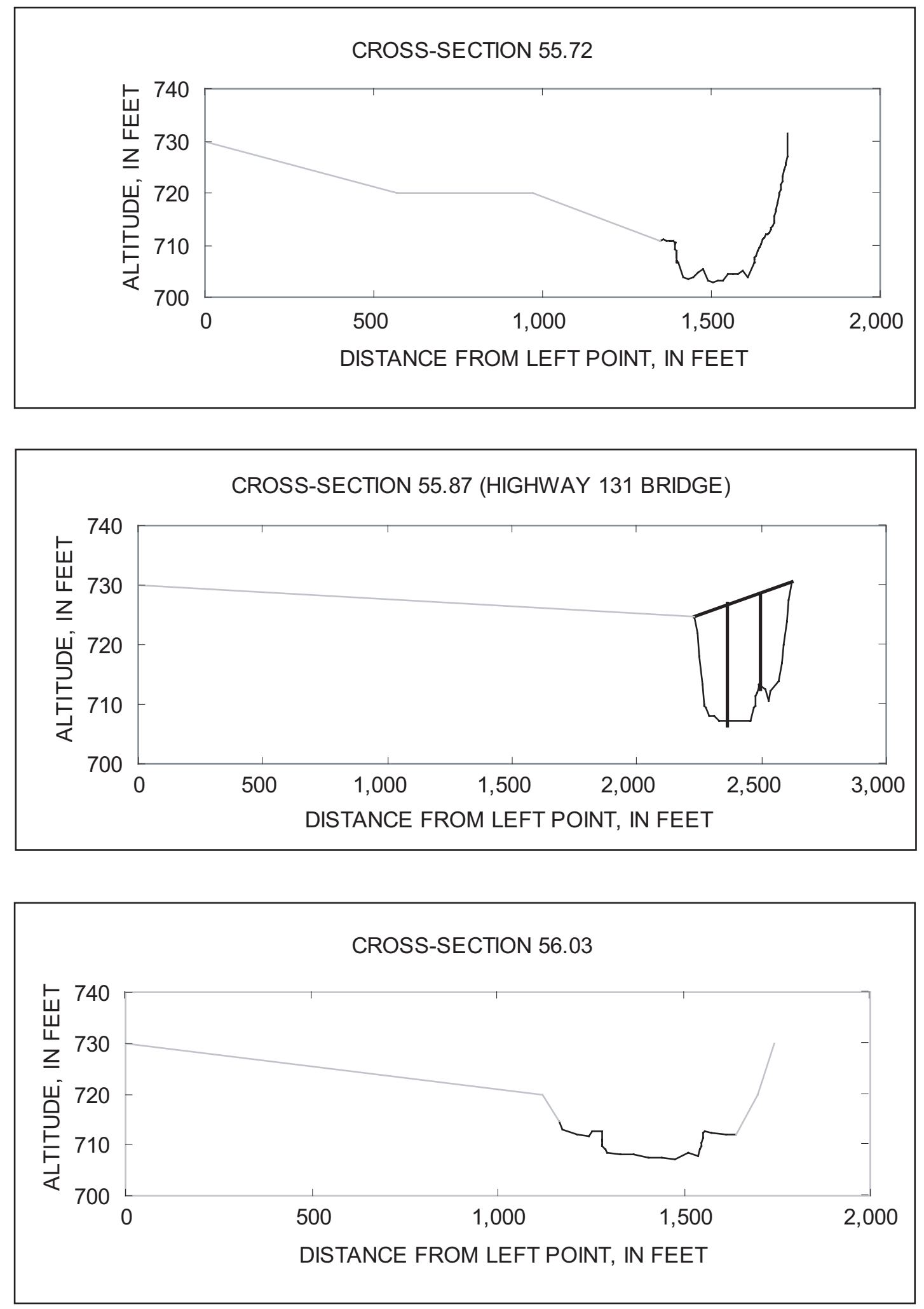
Appendix A. Valley and designed cross sections for the Kalamazoo River from Plainwell to Otsego, Michigan. Designed channel modifications shown by dashed line; cross-section extensions based on topographic map elevations shown in grey. Cross-section locations within study reach are shown on Figure 14 -- continued.
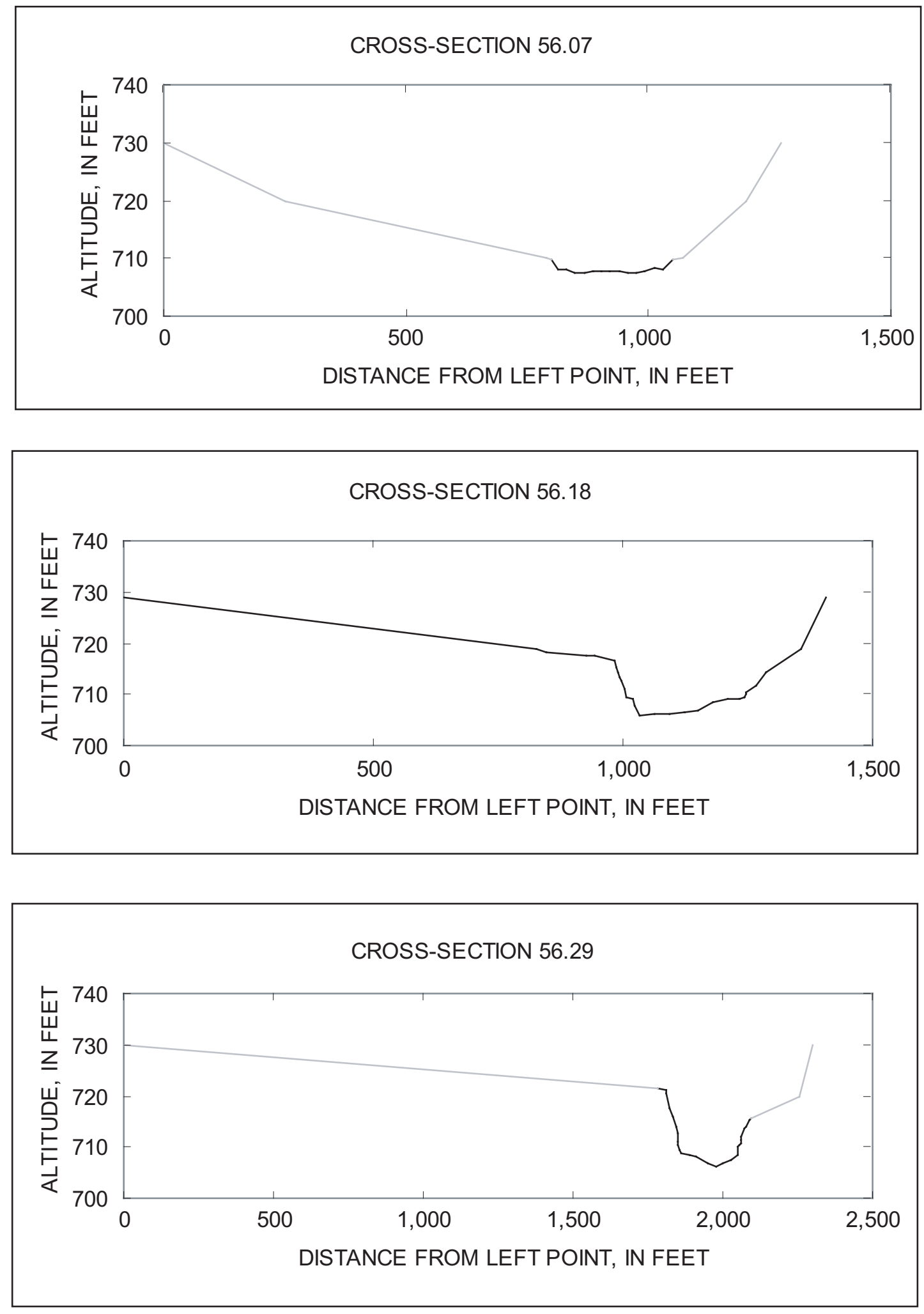
Appendix A. Valley and designed cross sections for the Kalamazoo River from Plainwell to Otsego, Michigan. Designed channel modifications shown by dashed line; cross-section extensions based on topographic map elevations shown in grey. Cross-section locations within study reach are shown on Figure 14 -- continued.
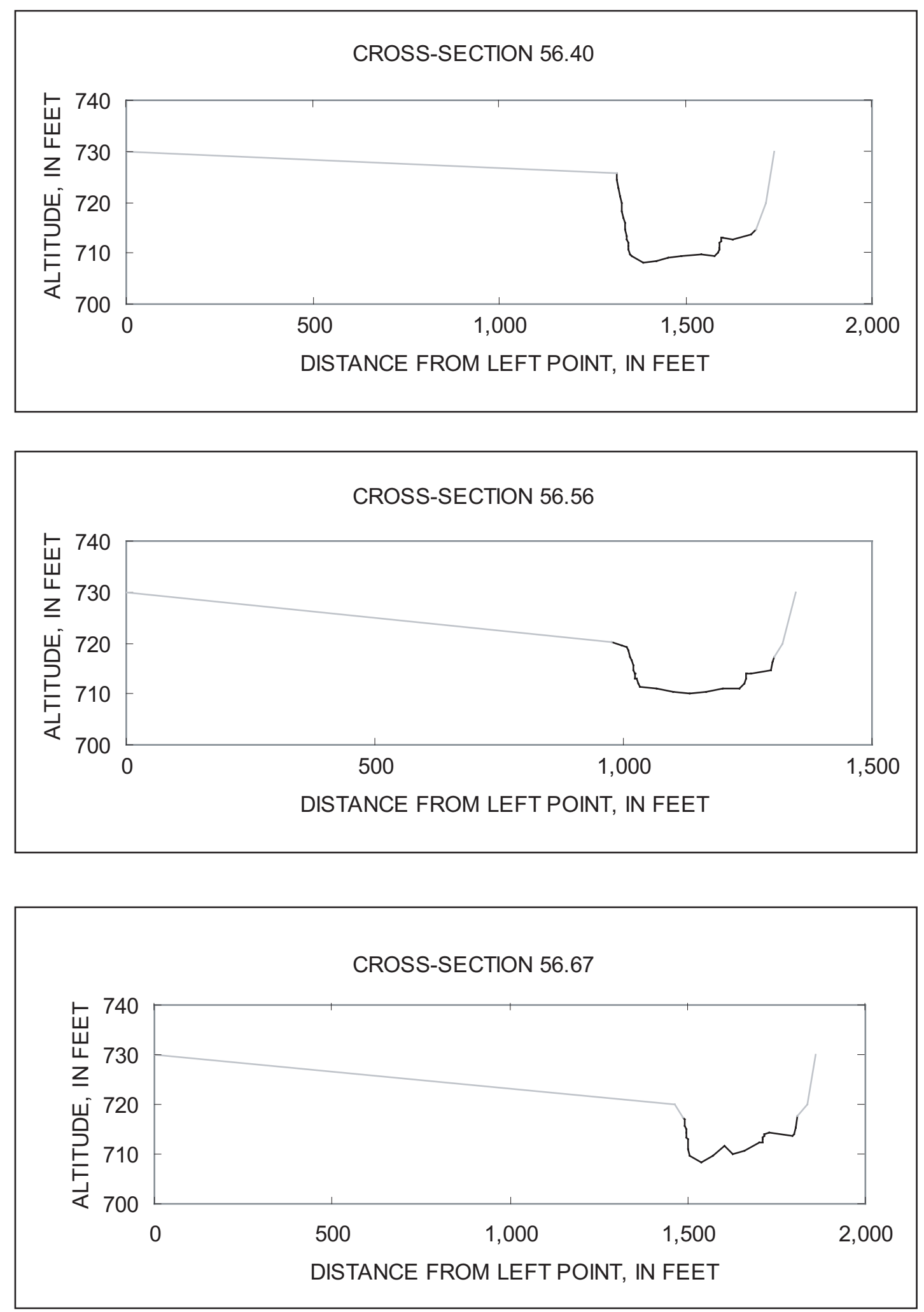
Appendix B. Geotechnical parameters from field tests of streambanks for the Kalamazoo River from Plainwell to Otsego, Michigan 
Appendix B. Geotechnical parameters from field tests of streambanks for the Kalamazoo river from Plainwell to Otsego, Michigan. Streambank locations within study reach are shown on Figure 11. [ ${ }^{*}$, denotes locations where the average of multiple field tests were presented; Abbreviations: $c_{a}$, apparent cohesion; $c^{\prime}, c$ cohesion; $\phi^{\prime}$, internal friction angle; $\gamma$, saturaded unit weight; $\tau_{\mathrm{c}}$, critical shear stress; $k$, erodibility; $\mathrm{kPa}$, kilo-Pascals; $\mathrm{kN} / \mathrm{m}^{3}$, kilo-Newton per cubic meter; $\mathrm{Pa}$, Pascal; $\mathrm{cm}^{3} / \mathrm{N}-\mathrm{s}$, cubic centimeter per Newton per second; --, no data]

\begin{tabular}{|c|c|c|c|c|c|c|c|c|}
\hline \multirow[b]{2}{*}{ River mile } & \multicolumn{6}{|c|}{ Bank Layer properties } & \multicolumn{2}{|c|}{ Bank Toe Properties } \\
\hline & $\begin{array}{l}\text { Layer from } \\
\text { top of bank }\end{array}$ & $\begin{array}{l}\text { Depth of layer from top } \\
\text { down to river bottom (m) }\end{array}$ & $\begin{array}{c}\mathrm{c}_{\mathrm{a}} \\
(\mathrm{kPa})\end{array}$ & $\begin{array}{c}\mathrm{c}^{\prime} \\
(\mathrm{kPa})\end{array}$ & $\begin{array}{c}\phi^{\prime}, \text { in } \\
\text { degrees }\end{array}$ & $\gamma\left(\mathrm{kN} / \mathrm{m}^{3}\right)$ & $\begin{array}{c}\tau_{C} \\
(\mathrm{~Pa})\end{array}$ & $k\left(\mathrm{~cm}^{3} / \mathrm{N}-\mathrm{s}\right)$ \\
\hline $\begin{array}{l}56.67 \\
56.67\end{array}$ & $\begin{array}{l}1 \\
2\end{array}$ & $\begin{array}{c}0-5.0 \\
5.1-6.6\end{array}$ & $\begin{array}{l}5.0 \\
4.6\end{array}$ & $\begin{array}{r}.0 \\
4.3\end{array}$ & $\begin{array}{l}24.2 \\
21.9\end{array}$ & $\begin{array}{l}16.0 \\
10.6\end{array}$ & 12.2 & .69 \\
\hline $\begin{array}{l}56.29 \\
56.29\end{array}$ & $\begin{array}{l}1 \\
2\end{array}$ & $\begin{array}{c}0-1.53 \\
1.54-4.6\end{array}$ & $\begin{array}{l}2.2 \\
3.9\end{array}$ & $\begin{array}{r}.8 \\
1.4\end{array}$ & $\begin{array}{l}40.6 \\
27.9\end{array}$ & $\begin{array}{r}9.1 \\
16.0\end{array}$ & 11.3 & .13 \\
\hline $\begin{array}{l}56.03 \\
56.03\end{array}$ & $\begin{array}{l}1 \\
2\end{array}$ & $\begin{array}{c}0-5.5 \\
5.5-7.0\end{array}$ & $\begin{array}{l}1.9 \\
9.8\end{array}$ & $\begin{array}{r}.0 \\
8.2\end{array}$ & $\begin{array}{l}25.7 \\
21.2\end{array}$ & $\begin{array}{l}15.6 \\
18.0\end{array}$ & 2.0 & .07 \\
\hline $\begin{array}{l}55.87 \\
55.87\end{array}$ & $\begin{array}{l}1 \\
2\end{array}$ & $\begin{array}{c}0-3.0 \\
3.1-5.1\end{array}$ & $\begin{array}{l}1.9 \\
9.8\end{array}$ & $\begin{array}{r}.0 \\
8.2\end{array}$ & $\begin{array}{l}25.7 \\
21.2\end{array}$ & $\begin{array}{l}18.0 \\
12.7\end{array}$ & 9.8 & 1.71 \\
\hline $\begin{array}{l}55.72 \\
55.72\end{array}$ & $\begin{array}{l}1 \\
2\end{array}$ & $\begin{array}{c}0-5.6 \\
5.61-8.6\end{array}$ & $\begin{array}{l}2.7 \\
4.9\end{array}$ & $\begin{array}{r}.0 \\
4.0\end{array}$ & $\begin{array}{l}27.5 \\
23.8\end{array}$ & $\begin{array}{l}16.4 \\
10.1\end{array}$ & 18.0 & .44 \\
\hline $\begin{array}{l}55.62 \\
55.62\end{array}$ & $\begin{array}{l}1 \\
2\end{array}$ & $\begin{array}{c}0-4.5 \\
4.51-8.5\end{array}$ & $\begin{array}{l}6.2 \\
6.1\end{array}$ & $\begin{array}{l}2.1 \\
4.0\end{array}$ & $\begin{array}{l}23.2 \\
18.7\end{array}$ & $\begin{array}{l}16.7 \\
11.3\end{array}$ & 7.9 & 1.14 \\
\hline 55.45 & 1 & $0-3.7$ & 3.7 & 1.9 & 23.5 & 15.0 & 2.0 & .07 \\
\hline $\begin{array}{l}55.3 \\
55.3\end{array}$ & $\begin{array}{l}1 \\
2\end{array}$ & $\begin{array}{c}0-2.2 \\
2.3-5.8\end{array}$ & $\begin{array}{r}.0 \\
6.7\end{array}$ & $\begin{array}{r}.0 \\
6.1\end{array}$ & $\begin{array}{l}30.0 \\
20.4\end{array}$ & $\begin{array}{r}* 15.9 \\
11.6\end{array}$ & 24.0 & 1.63 \\
\hline $\begin{array}{l}55.2 \\
55.2 \\
55.2\end{array}$ & $\begin{array}{l}1 \\
2 \\
3\end{array}$ & $\begin{array}{c}0-1.7 \\
1.71-2.7 \\
2.71-6.2\end{array}$ & $\begin{array}{c}3.7 \\
.0 \\
10.2\end{array}$ & $\begin{array}{c}1.9 \\
.0 \\
10.7\end{array}$ & $\begin{array}{l}23.5 \\
35.0 \\
14.6\end{array}$ & $\begin{array}{r}15.7 \\
* 15.9 \\
16.9\end{array}$ & 72.2 & .85 \\
\hline $\begin{array}{l}55.1 \\
55.1\end{array}$ & $\begin{array}{l}1 \\
2\end{array}$ & $\begin{array}{c}0-4.93 \\
4.94-7.5\end{array}$ & $\begin{array}{c}10.2 \\
8.8\end{array}$ & $\begin{array}{l}4.5 \\
7.8\end{array}$ & $\begin{array}{l}16.7 \\
12.5\end{array}$ & $\begin{array}{l}14.9 \\
12.9\end{array}$ & 4.7 & 5.79 \\
\hline $\begin{array}{l}55.01 \\
55.01\end{array}$ & $\begin{array}{l}1 \\
2\end{array}$ & $\begin{array}{c}0-4.1 \\
4.2-6.6\end{array}$ & $\begin{array}{c}5.5 \\
16.0\end{array}$ & $\begin{array}{c}3.3 \\
13.7\end{array}$ & $\begin{array}{l}11.2 \\
26.6\end{array}$ & $\begin{array}{l}15.2 \\
12.5\end{array}$ & 7.8 & 1.24 \\
\hline $\begin{array}{l}54.68-\mathrm{L} \\
54.68-\mathrm{L}\end{array}$ & $\begin{array}{l}1 \\
2\end{array}$ & $\begin{array}{c}0-0.42 \\
0.43-2.2\end{array}$ & $\begin{array}{l}.4 \\
.0\end{array}$ & $\begin{array}{l}.1 \\
.0\end{array}$ & $\begin{array}{l}29.1 \\
30.0\end{array}$ & $\begin{array}{r}12.9 \\
* 15.9\end{array}$ & -- & -- \\
\hline $\begin{array}{l}54.68-R \\
54.68-\mathrm{R}\end{array}$ & $\begin{array}{l}1 \\
2\end{array}$ & $\begin{array}{c}0-0.50 \\
0.51-1.20\end{array}$ & $\begin{array}{l}2.2 \\
6.8\end{array}$ & $\begin{array}{l}2.1 \\
5.7\end{array}$ & $\begin{array}{l}31.4 \\
35.0\end{array}$ & $\begin{array}{l}12.7 \\
11.5\end{array}$ & 2.0 & .07 \\
\hline 54.61-L & 1 & $0-1.9$ & 8.9 & 7.6 & 19.8 & 15.0 & -- & -- \\
\hline $54.61-R$ & 1 & $0-0.82$ & 2.3 & 2.1 & 10.9 & 13.8 & .23 & .20 \\
\hline 54.54 & 1 & $0-2.6$ & .3 & .0 & 19.1 & 12.5 & .22 & .21 \\
\hline 54.46 & 1 & $0-2.4$ & 5.2 & 4.4 & 24.0 & 12.5 & 2.0 & .07 \\
\hline 54.12 & 1 & $0-3.9$ & 6.3 & 6.2 & 16.9 & 9.7 & 2.0 & .07 \\
\hline 53.73 & 1 & $0-1.7$ & 3.6 & 3.2 & 19.4 & 16.2 & 2.0 & .07 \\
\hline 53.19 & 1 & $0-4.0$ & 2.3 & .0 & 10.9 & 7.4 & 2.6 & 5.27 \\
\hline 52.59 & 1 & $0-5.2$ & 3.7 & 3.4 & 29.3 & 14.8 & .2 & .22 \\
\hline 52.25 & 1 & $0-4.1$ & .2 & .0 & 11.2 & 15.8 & -- & -- \\
\hline 51.83 & 1 & $0-9.8$ & 3.6 & 1.6 & 21.3 & 17.2 & 1.1 & .10 \\
\hline $\begin{array}{l}51.43 \\
51.43\end{array}$ & $\begin{array}{l}1 \\
2\end{array}$ & $\begin{array}{c}0-5.5 \\
5.6-8.3\end{array}$ & $\begin{array}{l}3.6 \\
4.7\end{array}$ & $\begin{array}{r}1.6 \\
.0\end{array}$ & $\begin{array}{l}21.3 \\
30.0\end{array}$ & $\begin{array}{c}17.2 \\
9.3\end{array}$ & 4.4 & .47 \\
\hline 51.23 & 1 & $0-11.58$ & 0.0 & 0.0 & 29.7 & 14.6 & -- & -- \\
\hline
\end{tabular}


Appendix C. Maps showing channel change from early to mid-1830s to 1999 at selected locations on the Kalamazoo River, Michigan. 


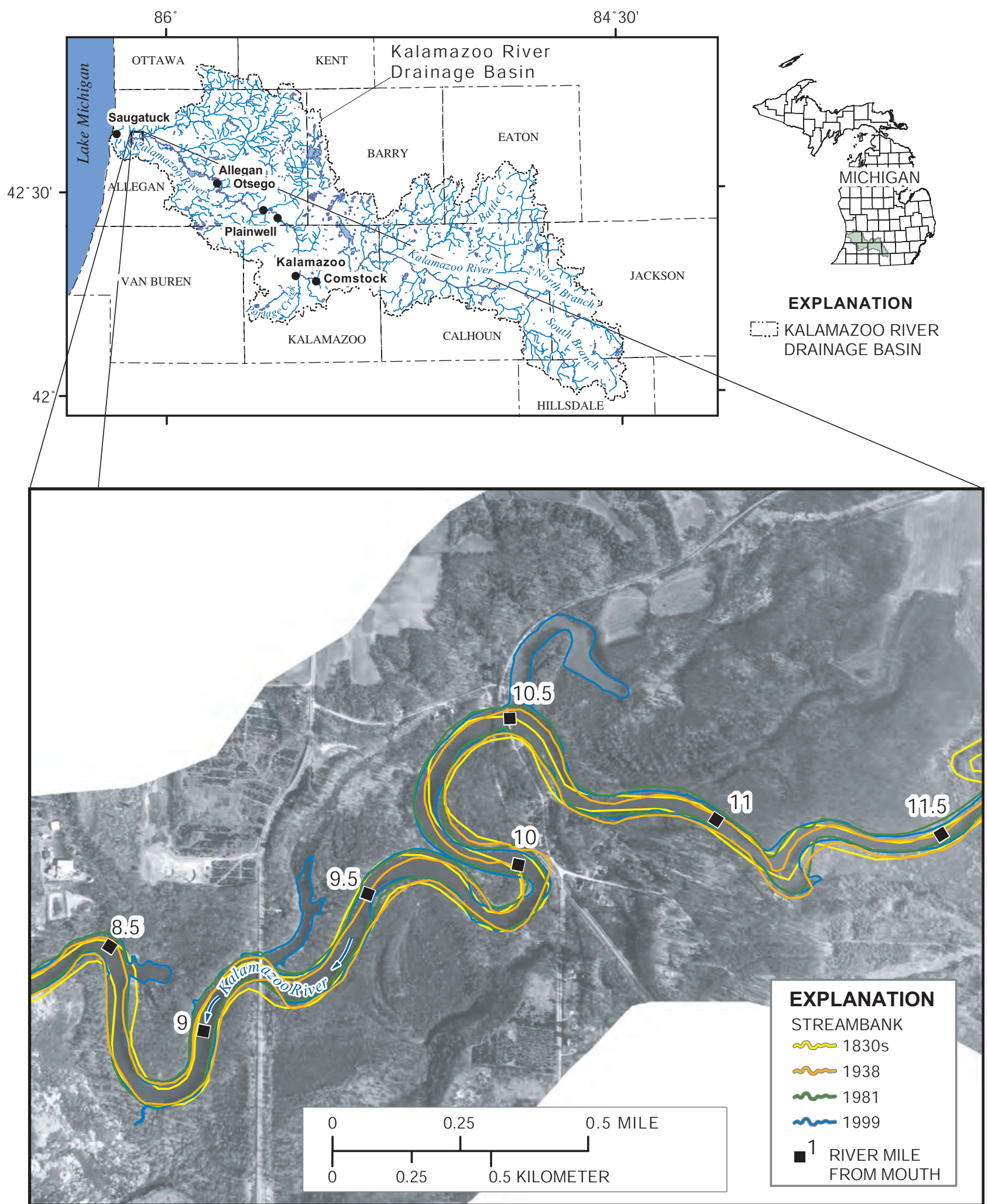

City names and locations from U.S. Geological Survey digital raster graphics. Hydrologic divides from Michigan Department of Environmental Quality Land and Water Management. Hydrologic features and county boundaries from Michigan Resource Information System. 1999 aerial photographs courtesy

Figure projection is Hotine Oblique Mercator, Type 2, Scale factor at the projection's center 0.9996; longitude of the projection's center $860000 \mathrm{~W}$; latitude of the projection's of Camp, Dresser, and McKee.

Appendix C1. Channel change, 1830s to 1999, Kalamazoo River mile 8.5 to 11.5, Michigan. 


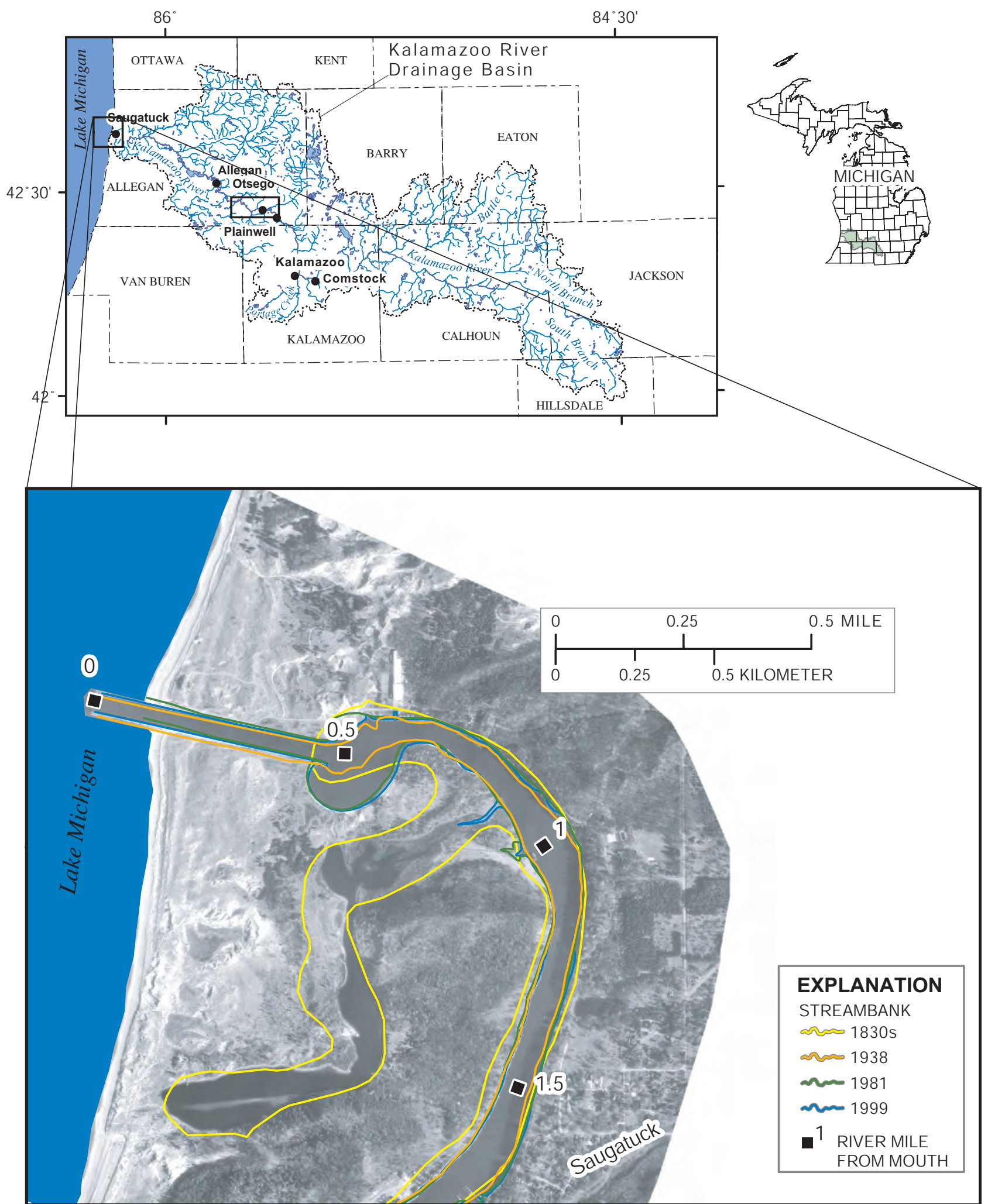

City names and locations from U.S. Geological Survey digital raster graphics. Hydrologic divides from Michigan Department of Environmental Quality Land and Water Management. Hydrologic features and county boundaries from

Figure projection is Hotine Oblique Mercator, Type 2, Scale factor at the projection's Michigan Resource Information System. 1999 aerial photographs courtesy center 0.9996; longitude of the projection's center $860000 \mathrm{~W}$; latitude of the projection's of Camp, Dresser, and McKee.

Appendix C2. Channel change, 1830s to 1999, Kalamazoo River mouth near Saugatuck, Michigan. 


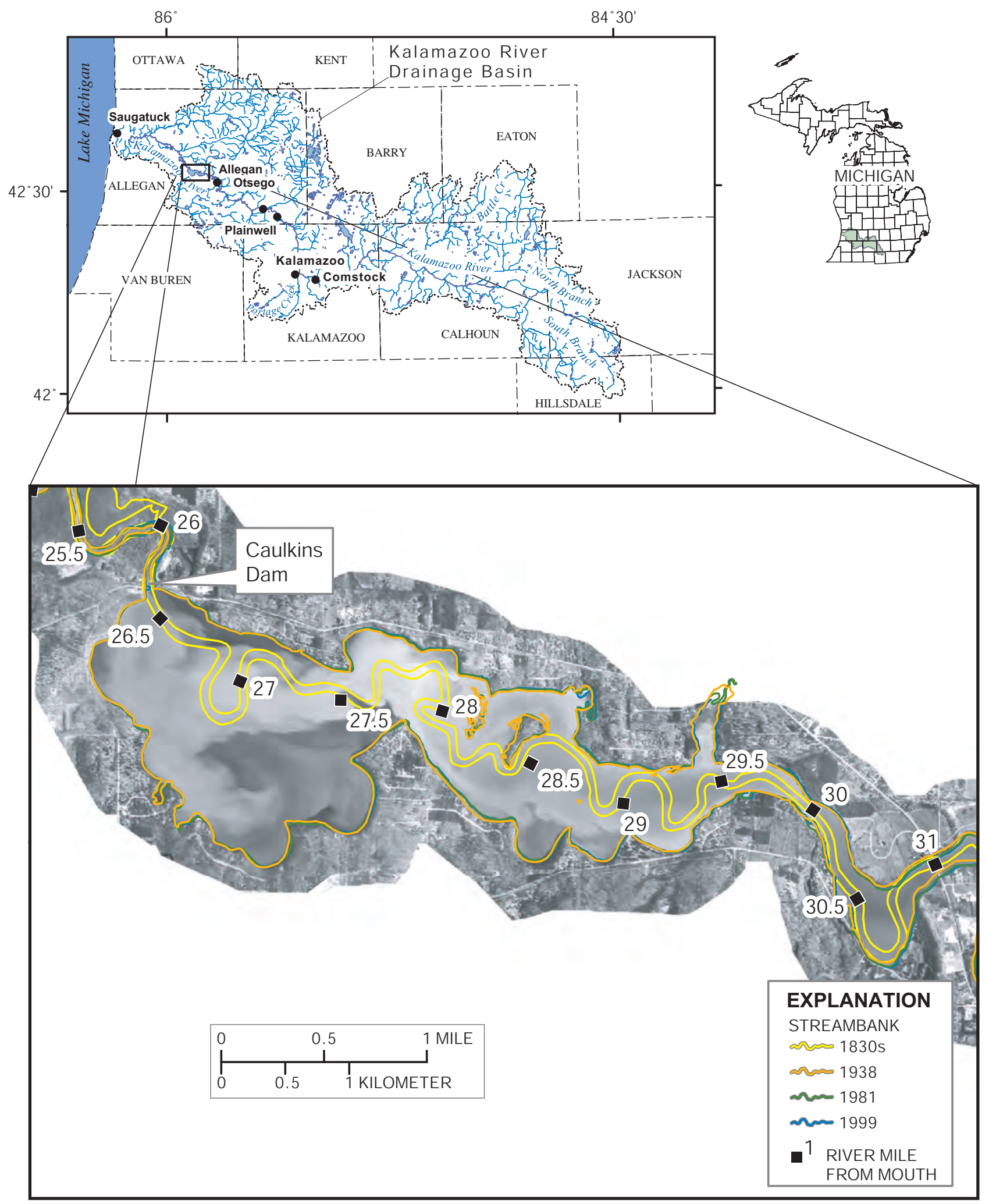

City names and locations from U.S. Geological Survey digital raster graphics. Hydrologic divides from Michigan Department of Environmental Quality Land and Water Management. Hydrologic features and county boundaries from

Figure projection is Hotine Oblique Mercator, Type 2, Scale factor at the projection's center 0.9996; longitude of the projection's center $860000 \mathrm{~W}$; latitude of the projection's Michigan Resource Information System. 1999 aerial photographs courtesy center $451833 \mathrm{~N}$ : Azimuth at the projection's center 337.25555555556. of Camp, Dresser, and McKee.

Appendix C3. Channel change, 1830s to 1999, Kalamazoo River through Caulkins Dam, Michigan. 


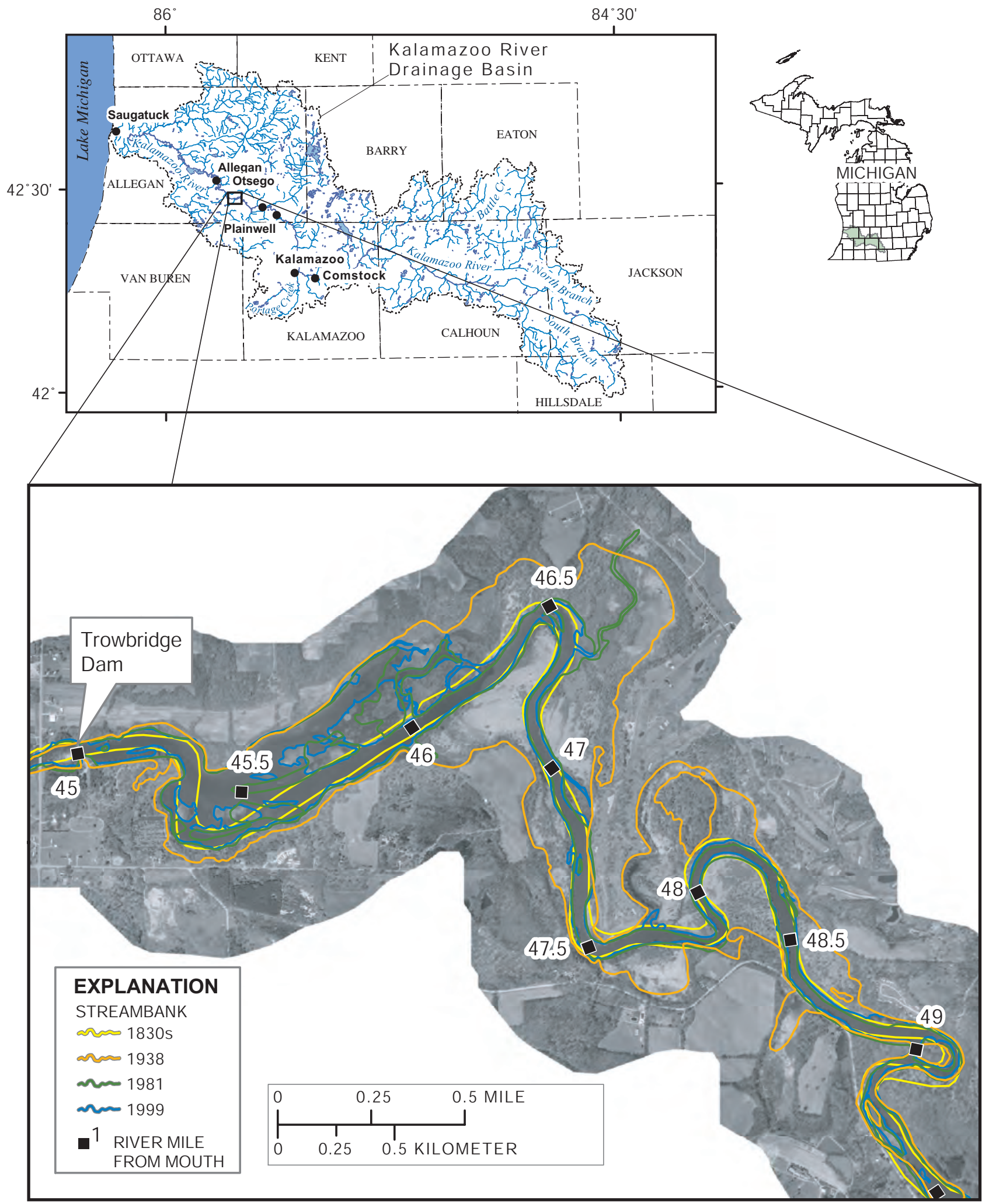

City names and locations from U.S. Geological Survey digital raster graphics. Hydrologic divides from Michigan Department of Environmental Quality Land and Water Management. Hydrologic features and county boundaries from Michigan Resource Information System. 1999 aerial photographs courtesy

Fiqure projection is Hotine Oblique Mercator, Type 2, Scale factor at the projection's center 0.9996; longitude of the projection's center $860000 \mathrm{~W}$; latitude of the projection's of Camp, Dresser, and McKee.

Appendix C4. Channel change, 1830s to 1999, Kalamazoo River through Trowbridge Dam, Michigan. 


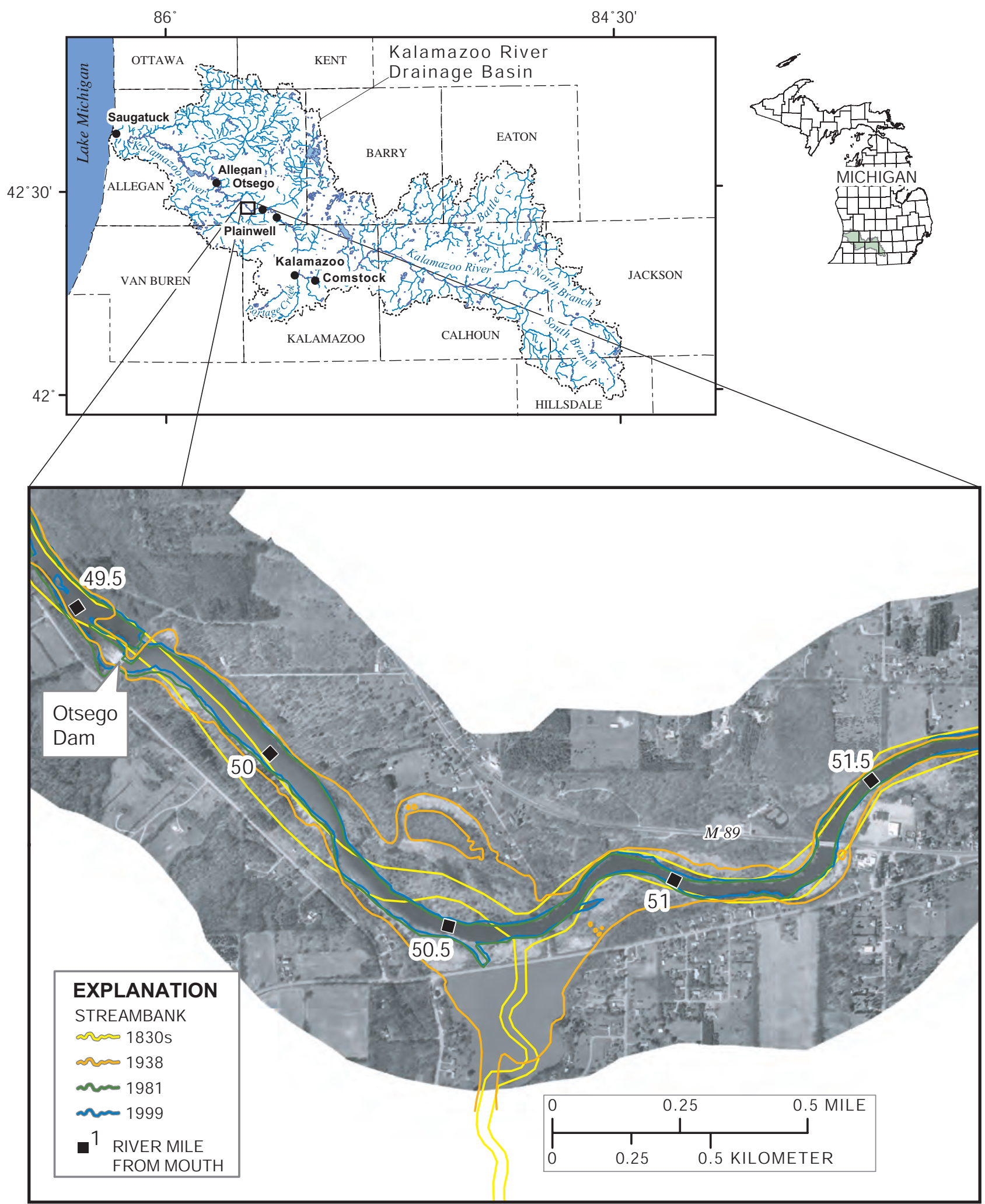

City names and locations from U.S. Geological Survey digital raster graphics. Hydrologic divides from Michigan Department of Environmental Quality Land and Water Management. Hydrologic features and county boundaries from Michigan Resource Information System. 1999 aerial photographs courtesy

Figure projection is Hotine Oblique Mercator, Type 2, Scale factor at the projection's center 0.9996: longitude of the projection's center $860000 \mathrm{~W}$; latitude of the projection's center $451833 \mathrm{~N}$; Azimuth at the projection's center 337.25555555556.

Appendix C5. Channel change, 1830s to 1999, Kalamazoo River through Otsego Dam, Michigan. 


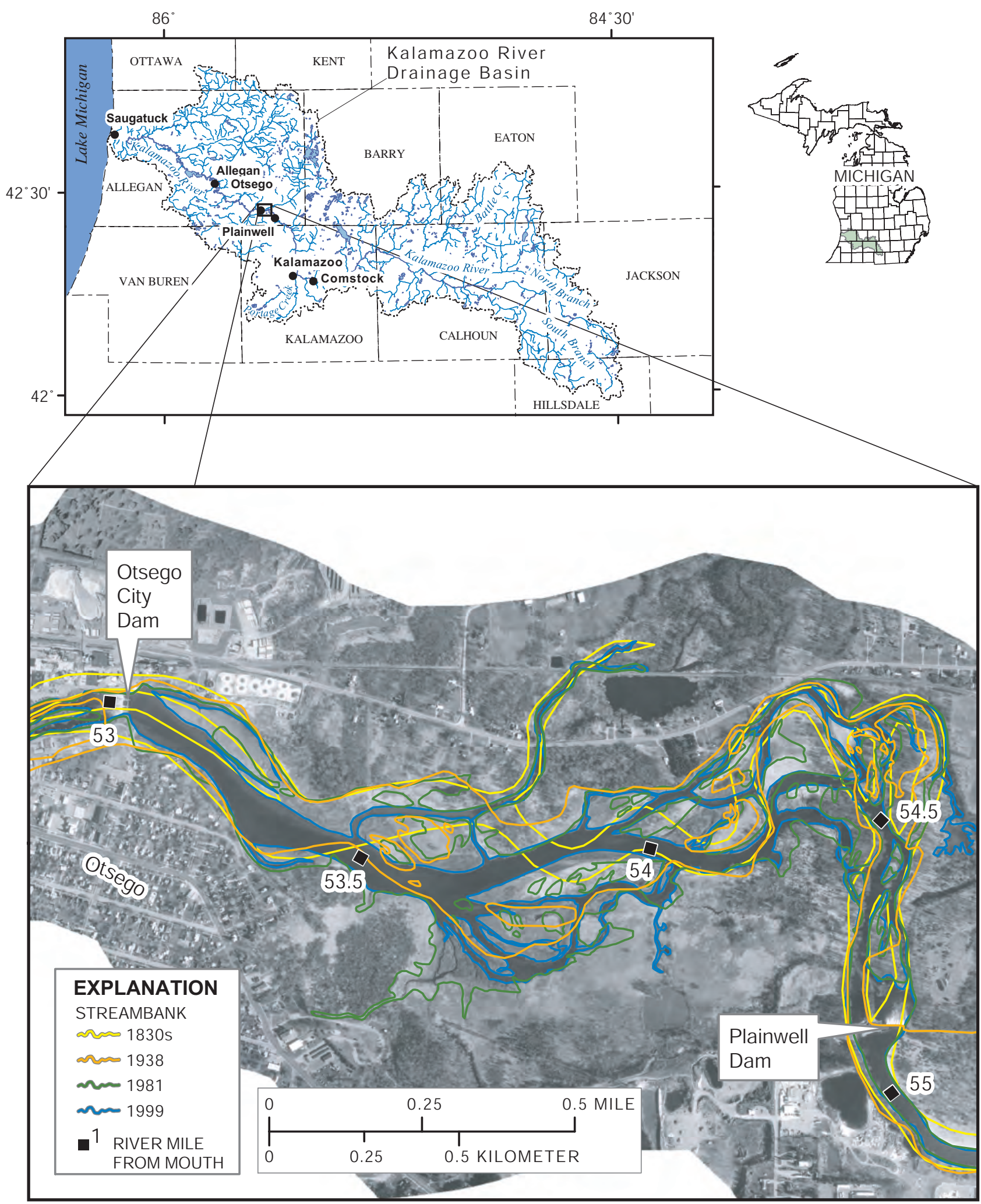

City names and locations from U.S. Geological Survey digital raster graphics.

Figure projection is Hotine Oblique Mercator, Type 2, Scale factor at the projection's Hydrologic divides from Michigan Department of Environmental Quality Land and Water Management. Hydrologic features and county boundaries from center 0.9996: Iongitude of the projection's center $860000 \mathrm{~W}$. latitude of the projection's Michigan Resource Information System. 1999 aerial photographs courtesy center $451833 \mathrm{~N}$. Azimuth at the projection's center 337.25555555556. of Camp, Dresser, and McKee.

Appendix C6. Channel change, 1830s to 1999, Kalamazoo River through Otsego City Dam, Michigan. 


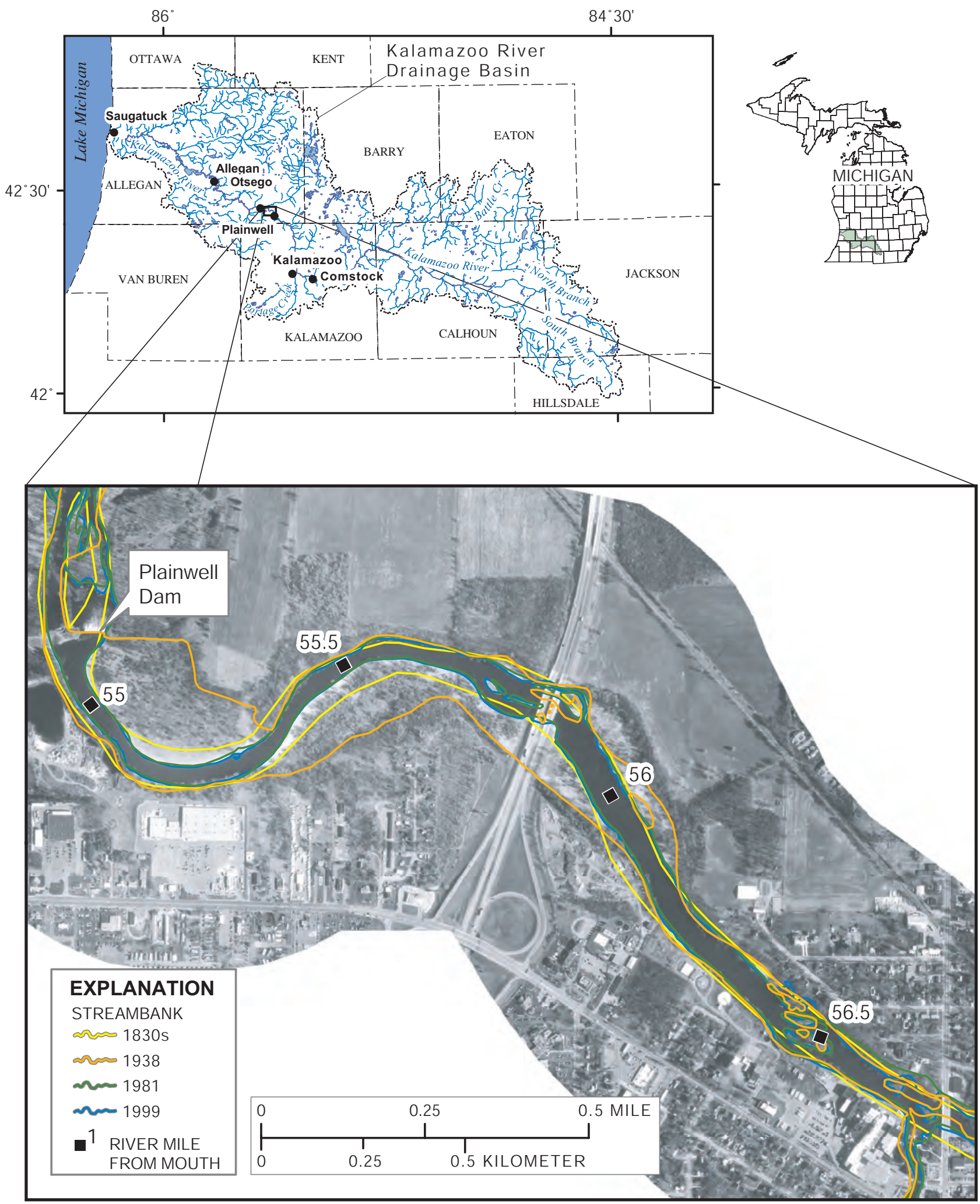

City names and locations from U.S. Geological Survey digital raster graphics. Hydrologic divides from Michigan Department of Environmental Quality Land and Water Management. Hydrologic features and county boundaries from Michigan Resource Information System. 1999 aerial photographs courtesy

Figure projection is Hotine Oblique Mercator, Type 2, Scale factor at the projection's center 0.9996; longitude of the projection's center $860000 \mathrm{~W}$; latitude of the projection's of Camp, Dresser, and McKee.

Appendix C7. Channel change, 1830s to 1999, Kalamazoo River through Plainwell Dam, Michigan. 


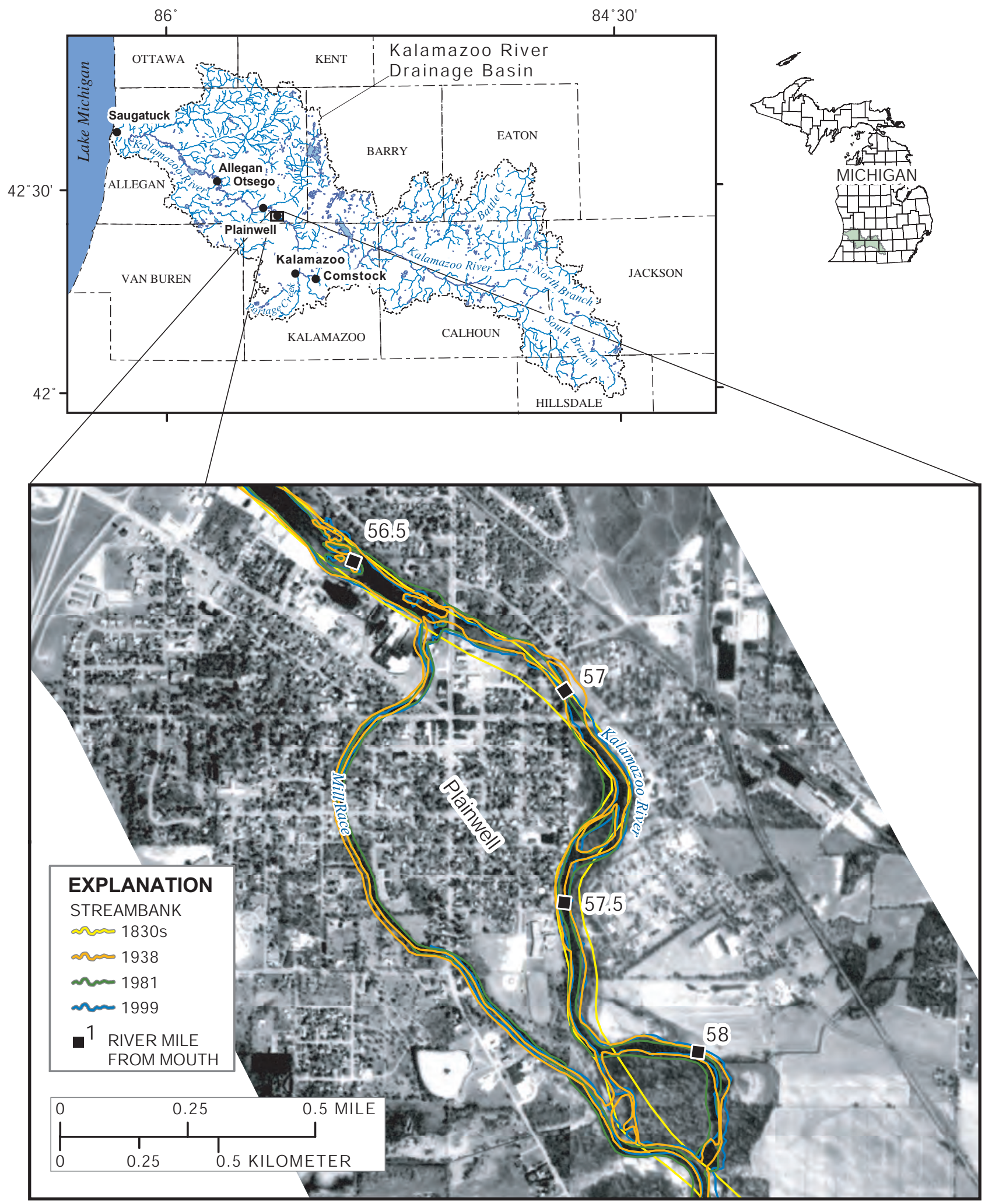

City names and locations from U.S. Geological Survey digital raster graphics. Hydrologic divides from Michigan Department of Environmental Quality Land and Water Management. Hydrologic features and county boundaries from Michigan Resource Information System. Inset base from USGS 1981 Aeria photograph mosaic.

Figure projection is Hotine Oblique Mercator, Type 2, Scale factor at the projection's center 0.9996; longitude of the projection's center $860000 \mathrm{~W}$; latitude of the projection's center $451833 \mathrm{~N} ;$ Azimuth at the projection's center 337.25555555556

Appendix C8. Channel change, 1830s to 1999, Kalamazoo River through the Plainwell Mill-race, Michigan. 


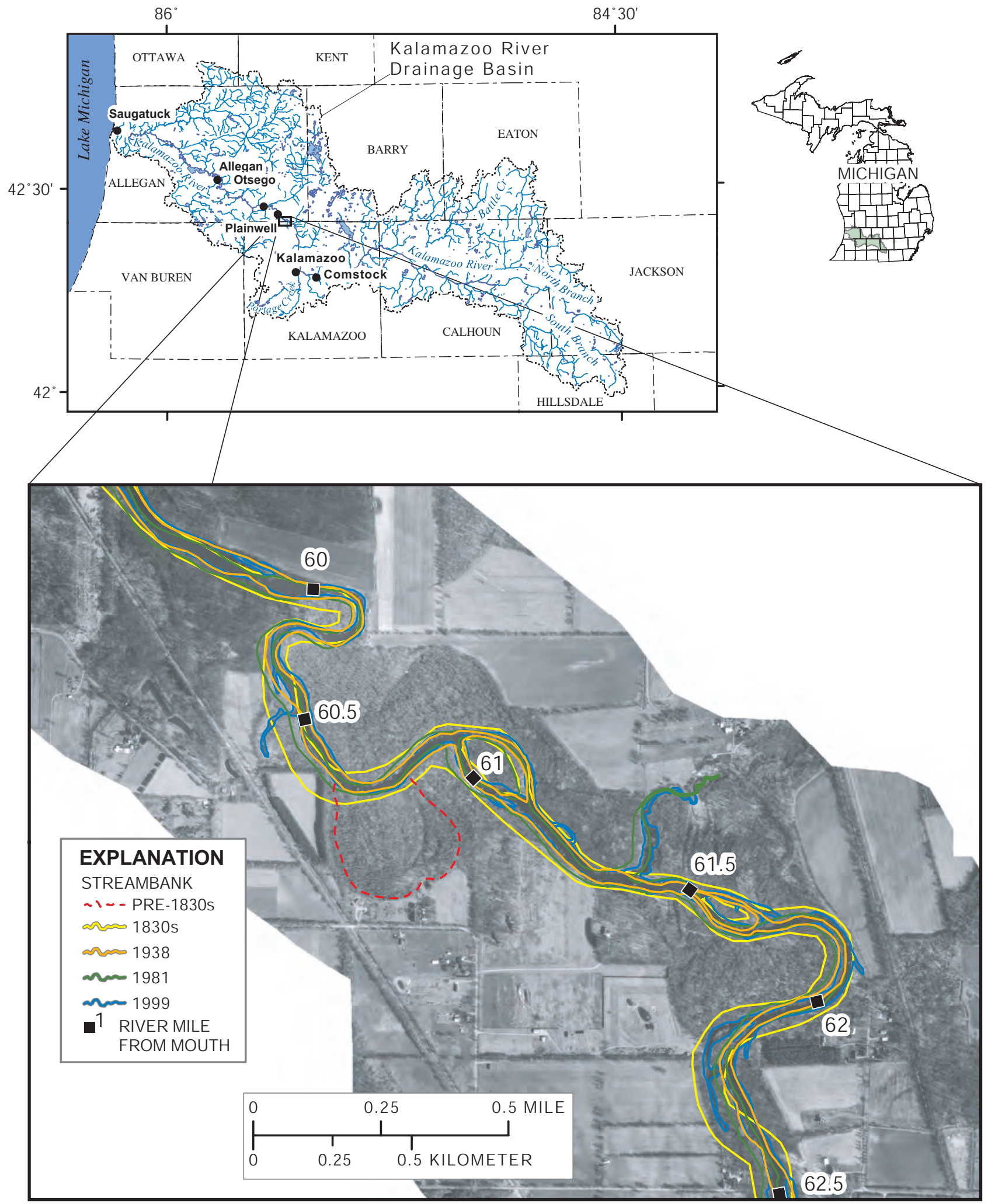

City names and locations from U.S. Geological Survey digital raster graphics. Hydrologic divides from Michigan Department of Environmental Quality Land and Water Management. Hydrologic features and county boundaries from Michigan Resource Information System. 1999 aerial photographs courtesy

Figure projection is Hotine Oblique Mercator, Type 2, Scale factor at the projection's Figure projection is Hotine Oblique Mercator, Type 2, Scale factor at the projection's
center 0.9996; Iongitude of the projection's center 860000 W; latitude of the projection's center $451833 \mathrm{~N}$; Azimuth at the projection's center 337.25555555556 .

Appendix C9. Channel change, 1830s to 1999, Kalamazoo River mile 60 to 62.5, Michigan. 


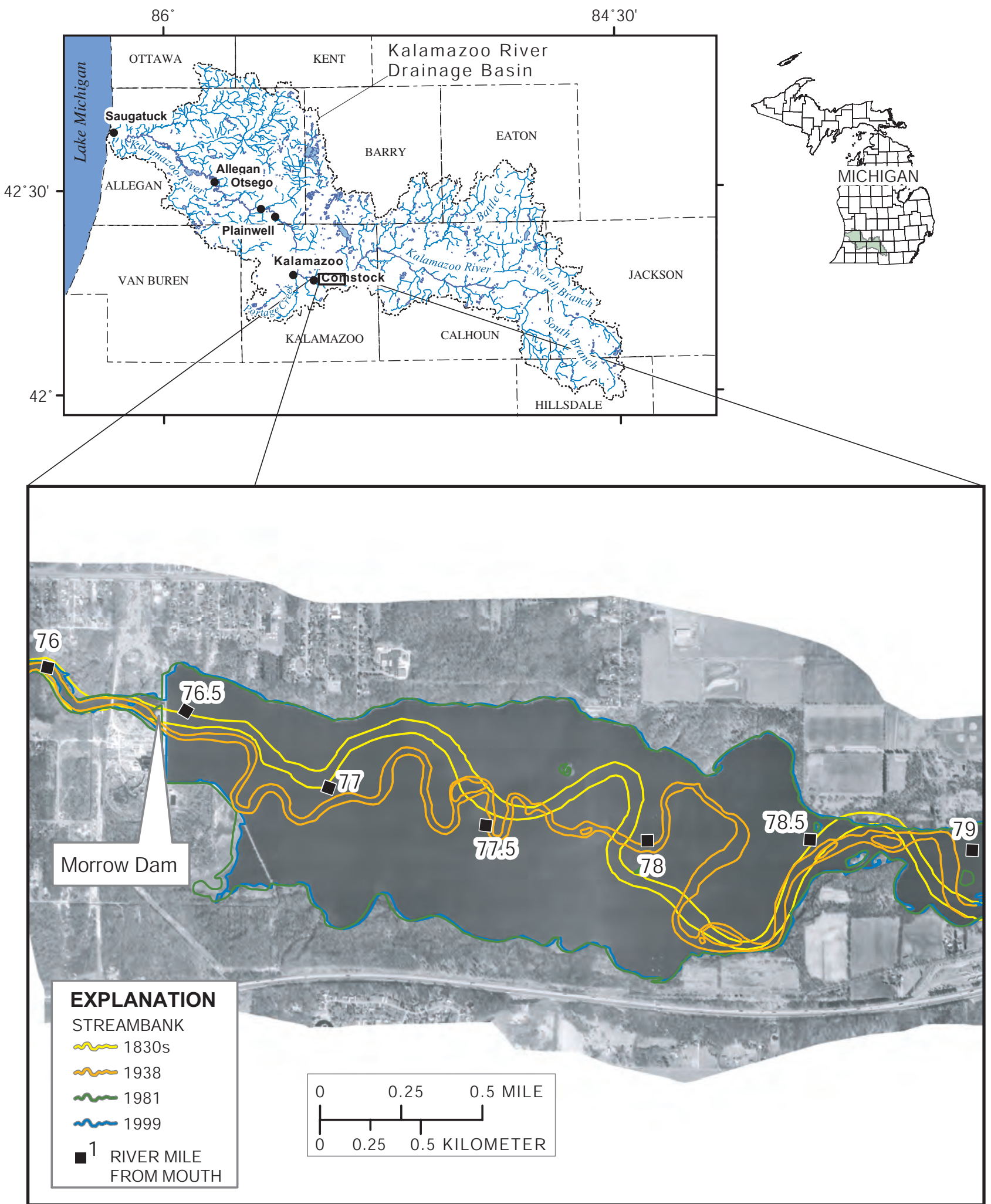

City names and locations from U.S. Geological Survey digital raster graphics. Hydrologic divides from Michigan Department of Environmental Quality Land and Water Management. Hydrologic features and county boundaries from

Figure projection is Hotine Oblique Mercator, Type 2, Scale factor at the projection's Michigan Resource Information System. 1999 aerial photographs courtesy center $451833 \mathrm{~N}$ : Azimuth at the projection's center 337.25555555556. of Camp, Dresser, and McKee.

Appendix C10. Channel change, 1830s to 1999, Kalamazoo River through Morrow Dam, Michigan. 


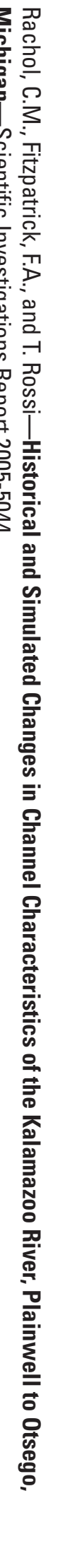

